Thiago de Oliveira Monaco

\title{
Ensaios sobre o surgimento, evolução e manutenção dos mecanismos de senescência em animais
}

Tese apresentada à Faculdade de Medicina da Universidade de São Paulo para obtenção do título de Doutor em Ciências

Área de Concentração: Patologia

Orientador: Prof. Dr. Paulo Sérgio Panse Silveira

São Paulo

2011 
Thiago de Oliveira Monaco

\section{Ensaios sobre o surgimento, evolução e manutenção dos mecanismos de senescência em animais}

Tese apresentada à Faculdade de Medicina da Universidade de São Paulo para obtenção do título de Doutor em Ciências

Área de Concentração: Patologia

Orientador: Prof. Dr. Paulo Sérgio Panse Silveira

São Paulo

2011 
Dados Internacionais de Catalogação da Publicação (CIP)

Preparada pela Biblioteca da

Faculdade de Medicina da Universidade de São Paulo

Creprodução autorizada pelo autor

Monaco, Thiago de Oliveira

Ensaios sobre o surgimento, evolução e manutenção dos mecanismos de senescência em animais / Thiago de Oliveira Monaco. - - São Paulo, 2011.

Tese(doutorado)- -Faculdade de Medicina da Universidade de São Paulo. Programa de Patologia.

Orientador: Paulo Sérgio Panse Silveira.

Descritores: 1.Senescência 2.Envelhecimento 3.Simulação por computador 4.Evolução biológica

USP/FM/DBD-133/11 


\section{Dedicatória}

À minha mãe, Regina, que além de me mostrar a alegria de viver, sempre acreditou em mim antes de todos e manteve sua fé em meu potencial quando eu mesmo duvidei. Muitas vezes.

Ao meu pai, Afonso, que me incentivou nas áreas do intelecto sempre que pôde: nunca esquecerei o gelo se fundindo na panela do fogão há mais de 25 anos, revelando os estados da matéria muito antes da época escolar.

A ambos, pelos sacrifícios voluntários e acumulados ao longo de boa parte de suas vidas em prol de seus filhos e de seus pais: Amor non quaerit causam, nec fructum.

A meus avós, André, Euclydia, José e Maria, por tanto amor e cuidado, e por me fazerem irremediavelmente contaminado com a causa do envelhecimento e do idoso.

Ao meu irmão, por deixar claro com tão poucas palavras ser capaz de me amparar imediatamente se um dia preciso for.

À minha esposa e amiga, Adriana Bavagnoli Monaco, por confiar, acreditar, apoiar, empurrar, amar. Amar principalmente no sentido mais generoso da palavra: tolerar a ausência, confiar nas minhas escolhas, acreditar no meu sucesso, apoiar-me quando um Atlas me faltava, empurrar-me ladeira acima. Não haverá agradecimentos suficientes. 
Ao Wilson, por inspirar, ensinar, acreditar e direcionar meus caminhos na Medicina e na Pesquisa.

Ao Paulo, por superar as expectativas mais ambiciosas em relação a um orientador, e por ter se tornado neste processo um grande amigo.

Aos muitos amigos, que me escutaram e apoiaram.

A todos meu reconhecimento e profundo agradecimento. Sem o tanto que cada um me ofereceu, este momento não teria sido sonhado, planejado ou executado. 


\section{Agradecimentos}

Tentarei agradecer em ordem cronológica e lógica aqueles que foram diretamente essenciais para a realização desta tese. Esta ordem não significa a importância de cada um, pois, sem a ajuda de qualquer deles, este trabalho seria hoje, para dizer pouco, inferior; para dizer a verdade, impossível. Especificamente, sou muito grato:

- Ao Prof. Dr. Wilson Jacob Filho, que acreditou que havia algo de relevante na minha conversa estranha sobre os artigos que eu havia lido em 2005 sobre senescẽncia e evolução; por ter acreditado que eu realmente via um hiato na literatura; por ter acreditado apesar dos pesares que eu poderia fazer algo de relevante e, finalmente, por ter imediatamente promovido e participado de meu encontro com o Prof. Dr. Eduardo Massad naquele ano;

- Ao Prof. Dr. Eduardo Massad, que, após ouvir uma apresentação infinitamente crua, acreditou que eu poderia ter percebido algo ainda não explicado em reação às teorias de evolução da senescência e que eu poderia tentar atacar este hiato através de simulações computacionais; agradeço ainda por sua generosidade em ouvir um candidato ao início da pós-graduação que sabia tão pouco sobre evolução, senescência, matemática e simulações, assuntos sobre os quais ele sabe muito; agradeço por ter me apresentado ao Prof. Dr. Paulo Silveira, recentemente retornado de seu Pós-Doutorado na Universidade de Harvard; finalmente, agradeço-o ainda por apontar-me, durante a qualificação, em que direções eu ainda precisava muito me aprimorar; 
- Ao Prof. Dr. Paulo Silveira, que, ao me ouvir, convidou-me imediatamente a submeter-lhe um anteprojeto de pesquisa; que, tendo-me aceitado pessoalmente como aluno antes mesmo do processo seletivo da pós-graduação da FMUSP, ajudou-me a tornar meu projeto mais robusto, com dicas de artigos, de livros, de estilo de redação científica, de lógica de programação de sistemas e do potencial de simulações computacionais para estudos evolutivos, culminando com minha aceitação na pós-graduação, para apenas se dedicar ainda mais às minhas ideias e projetos e problemas; nestes poucos anos de convívio, sinto-me honrado de agradecer ao Professor Paulo por se mostrar um paradigma de de orientador acadêmico e sinto-me muito feliz por poder chamar o Paulo de meu amigo;

- À Profa. Dra. Neli Ortega, por me fazer questionar em seu curso de lógica fuzzy os paradigmas deterministas de nossa mente descontínua, que produziram a lógica discreta em chiaroscuro que tanto nos dificulta entender as realidades multitonais da biologia e da medicina;

- Ao Prof. Dr. José Ricardo Ayres, que, em seu excelente curso sobre aspectos filosóficos do conhecimento em saúde, fez-me aprender como a evolução dos paradigmas e dos progressos da ciência foram acompanhados ou talvez precedidos pela evolução no pensamento epistemológico, e o muito que isto significa para qualquer cientista que queira entender o que está fazendo quando faz ciência; ao mostrar como o progresso da ciência só foi possível pelo progresso de sua base epistemológica, ele me propiciou um ganho secundário: fez-me ver que eu só poderia entender bem a formulação de cada aspecto do pensamento em evolução da senescência se além de entender a moderna síntese evolutiva eu entendesse cada fase do progresso das teorias evolutivas da senescência em 
paralelo com o conhecimento e os paradigmas evolutivos das épocas em que cada progresso se deu;

- Ao Prof. Dr. Raymundo Soares de Azevedo Neto, que gentilmente cedeu recursos computacionais para que pudéssemos executar em tempo hábil as nossas simulações;

- Ao Daniel Silvestre, pelos ensinamentos em evolução, pela bibliografia que me inidicou, pela inestimável ajuda em identificar coisas úteis em meus insights, bem como me apontar que cientista trabalhou com cada um dos problemas que me inquietavam e pelo coleguismo que o levou a investir parte de seu tempo também escasso nos problemas que eu coloquei em evidência. Ouvir de alguém com o seu nível de conhecimento de matemática e evolução que as questões que eu levantei faziam sentido deram-me forte impuso para seguir em frente;

- A meu sogro, Carlo Bavagnoli, matemático e amigo, que me ajudou a superar parte da minha deficiência neste campo tão importante e que, mesmo nao tendo uma formação em biologia, procurou entender os problemas biológicos para me fazer entender meus problemas matemáticos;

- Ao software livre e a cada programador que abriu mão dos direitos de lucro sobre aquilo que criou em nome de um bem coletivo, sem o qual nada desta tese seria feito: desde a criação e execução de todos os modelos aqui descritos, até sua tabulação e análise estatistica, criação de gráficos e finalmente a redação desta tese, tudo foi realizado com a utilização do software livre. Agradeço especificamente aos criadores da plataforma Linux, do sistema operacional Ubuntu, do ambiente de programação Anjuta, da planilha Gnumeric, do ambiente estatístico $R$, do pacote de tipografia LATEX e do editor de $\mathrm{T}_{\mathrm{E}} \mathrm{X}$ Kile. 
"They must find it hard to take Truth for Authority who have so long mistaken

Authority for Truth."

- Gerald Massey (1828 - 1907)

"There is grandeur in this view of life, (...) having been originally breathed into a few forms (...), from so simple a beginning endless forms most beautiful and most wonderful have been, and are being, evolved." - Charles Darwin (1809 - 1882)

"The human tendency to regard little things as important has produced very many great things." - Georg Christoph Lichtenberg (1742 - 1799)

"Everything should be made as simple as possible, but no simpler." — Albert Einstein (1879 - 1955)

"Do not worry about your difficulties in Mathematics. I can assure you mine are still greater." — Albert Einstein (1879 - 1955) 


\section{Resumo}

Monaco TO. Ensaios sobre o surgimento, evolução e manutenção dos mecanismos de senescência em animais [tese]. São Paulo: Faculdade de Medicina, Universidade de São Paulo; 2011. 180p.

A base evolucionária da senescência é um problema biológico de longa data. Senescência, no sentido da deterioração progressiva de um organismo, distingue-se de envelhecimento, ou a mera passagem do tempo. Como, pelo menos em mamíferos, senescência e envelhecimento ocorrem simultaneamente, os termos são tomados erroneamente como sinônimos. A senescência parece explicada pelo desgaste do organismo, levando a um paradoxo frente aos mecanismos de seleção natural, pois, sendo a maquinaria biológica portadora de mecanismos de auto-reparo, esperaríamos o aprimoramento destes, com gradual eliminação da deterioração associada ao envelhecimento. Historicamente, procurou-se resolver este paradoxo imaginando-se que a senescência conferisse uma vantagem adaptativa, mas este argumento, que requereria distinguir os indivíduos mais velhos, é circular. A partir de meados do século XX, três hipóteses prevaleceram. O acúmulo de mutações, proposto por Medawar (1951), considera que o decaimento gradual da força de seleção com a idade favorece o acúmulo de genes deletérios expressos em idades avançadas. O antagonismo pleiotrópico, proposto por Williams (1957), defende que genes ligados a características benéficas e deletérias poderiam ser, em certas condições, favoravelmente selecionados. Finalmente, a teoria do soma descartável, proposta por Kirkwood (1975), sugere que organismos são favoravelmente selecionados quando investem em reprodução mesmo em detrimento da manutenção somática. A descrição dinâmica dos fenômenos envolvidos em cada hipótese e a contribuição relativa de cada uma é, ainda, objeto de debate. O presente trabalho visa ao desenvolvimento de modelos computacionais estocásticos que mimetizem as condições para cada uma delas. Iniciamos o desenvolvimento pela ordem histórica, testando o mecanismo proposto por Medawar, que é o objeto desta tese. A teoria do acúmulo de mutações encontrou críticos que sugerem que este mecanismo levaria os efeitos deletérios à sincronia em idades muito avançadas, tornando a senescência um fenômeno repentino e limitado a tais idades. Isto contrariaria a observação experimental, pois a senescência é um processo gradual e mesmo animais silvestres exibem fenômenos senescentes detectáveis precocemente. Para manter a modelagem compatível com o conhecimento atual sobre genética de populações, incluímos neste modelo os efeitos da seleção, da deriva genética e de diferentes taxas de mutação. Como previsto, em nossas simulações a moda das idades de manifestação dos genes deletérios se estabilizou apenas em ida- 
des muito avançadas, próximas ao término das distribuições etárias. Também como esperado, estas distribuições terminaram em idades mais precoces nos cenários de maior mortalidade extrínseca. No entanto, em todas as nossas simulações, houve distribuição mais ou menos larga das idades de manifestação em torno da moda. A distribuição alargou-se com o aumento da probabilidade de mutação, sugerindo que as idades de manifestação podem espalhar-se ao longo da vida, chegando, em alguns cenários, à manutenção de alelos com manifestação ao nascer. Isto é compatível com o modelo de alelos infinitos utilizado em genética populacional, em que diferentes variantes concorrem até atingirem um equilíbrio entre seleção, mutação e deriva genética. Considerando-se o critério demográfico para senescência, em que a mortalidade aumenta em função da idade, podemos dizer que as nossas simulações evoluíram populações senescentes. Embora nossos dados não contrariem as outras teorias da senescência, claramente mostram que a perda da força de seleção não é um mecanismo suficiente para a senescência. Especialmente com alelos de expressão tardia, as forças de deriva podem ser preponderantes e devem ser levadas em conta para explicar a evolução da senescência.

Descritores: Senescência, Envelhecimento, Simulações computacionais, Evolução biológica. 


\section{Abstract}

Monaco TO. Essays on the emergence, evolution and maintenance od senescence mechanisms in animals [thesis]. São Paulo: Faculty of Medicine, University of Sao Paulo; SP (Brazil); 2011. 180p.

The evolutionary basis of senescence is a long standing biological problem. Senescence, in the sense of progressive deterioration of an organism, is distinguished from aging, or the mere passage of time. Because, at least in mammals, aging and senescence occur simultaneously, the terms are wrongly taken as synonyms. Senescence seems explained by the wear of the organism, leading to a paradox facing the mechanisms of natural selection, because, being the biological machinery bearer of self-repair mechanisms, we would expect their improvement, with gradual elimination of the deterioration associated with aging. Historically, there were attempts to resolve this paradox by supposing that senescence confers an adaptive advantage, but this argument would require that older individuals were previously distinct from younger ones and is, therefore, circular. From mid-twentieth century, three hypotheses have prevailed. The mutation accumulation, proposed by Medawar (1951), proposes that the gradual decay of the force of selection with age favors the accumulation of deleterious genes expressed in advanced ages. The antagonistic pleiotropy, proposed by Williams (1957), argues that genes linked to beneficial and deleterious traits could, under certain conditions, be favorably selected. Finally, the disposable soma theory, proposed by Kirkwood (1975), suggests that organisms are positively selected when they invest in reproduction even at the expense of somatic maintenance. The dynamic description of the phenomena involved in each mechanism and the relative contribution of each one is still debated. The present work aims to develop stochastic computer models that mimic the conditions for each. We started by historical order, testing the mechanism proposed by Medawar, which is the subject of this thesis. The theory of mutation accumulation found critics who suggest that this mechanism would cause deleterious effects to synchronize in very advanced ages, causing senescence to be a sudden phenomenon limited to these ages. This is a contradiction with the experimental observation, because senescence is a gradual process and even wild animals exhibit senescent phenomena detectable in young ages. To keep the model consistent with the current knowledge on population genetics, this model included the effects of selection, genetic drift and different mutation rates. As predicted, in our simulations the mode of the age of onset of deleterious genes stabilized only in very advanced ages, near the end of the age distribution. Also as expected, these distributions ended in earlier ages in 
scenarios of higher extrinsic mortality. However, in all our simulations, there was more or less wide distribution of ages of onset around the mode. The distribution is enlarged with increased probabilities of mutation, suggesting that the ages of onset may spread throughout life, including, in some scenarios, the maintenance of alleles with manifestation at birth. This is consistent with the infinite alleles' model used in population genetics, where different variants compete until achieving an equilibrium between selection, mutation and genetic drift. Considering the demographic criterion for senescence, in which mortality increases with age, we can say that our simulations evolved senescent populations. Although our data do not conflict with the other theories of senescence, they clearly show that the falling force of selection with age is not a sufficient mechanism for senescence. Especially with alleles of late expression, the forces of genetic drift may be prominent and should be taken into account to explain the evolution of senescence.

Descriptors: Senescence, Aging, Computer simulations, Biological evolution. 


\section{Lista de Figuras}

Figura 2.1 - Evolução da capacidade funcional humana ao longo da vida. 13

Figura 2.2 - Mortalidade da população americana em 2007 (CDC, 2007). 16

Figura 2.3 - Mortalidade da população americana em 2007 (CDC, 2007). Escala logarítmica. . . . . . . . . . . . . . 16

Figura 2.4 - Curvas de sobrevivência para duas populações com diferentes mortalidades distintas mas mesma velocidade de senescência. . 18

Figura 2.5 - Curvas de sobrevivência da população americana em três diferentes períodos. . . . . . . . . . . . . 19

Figura 2.6 - Curva comparativa das trajetórias de mortalidade dehumanos e drosófilas. . . . . . . . . . . . . . . . . . 21

Figura 2.7 - Desaceleração tardia da mortalidade. . . . . . . . . . . . . . . 22

Figura 2.8 - Relação entre massa corpórea (M) e longevidade máxima (tmax) em vertebrados. ......................... 25

Figura 2.9 - Redundância e reserva funcional. Arranjo de sistemas com componentes em paralelo e em série. . . . . . . . . . . . 32

Figura 2.10 -Redundância e senescência. . . . . . . . . . . . . . . . . . 33

Figura 2.11 -Valor reprodutivo (v) em relação à idade e o modelo de senescência no ciclo de vida. . . . . . . . . . . . . . . . . . . . . . 39 
Figura 2.12 -Distribuição etária de suposta população não senescente exposta a uma mortalidade de $6,25 \%$ ao ano. . . . . . . . . . 46

Figura 2.13 -Distribuição etária da população afegã. . . . . . . . . . . . . 46

Figura 2.14 -Teorias evolutivas da senescência. . . . . . . . . . . . . . . 50

Figura 2.15 -Três modelos para a relação entre a fisiologia e a demografia da senescência. . . . . . . . . . . . . . . 53

Figura $2.16-\mathrm{O}$ salto do rato canguru. . . . . . . . . . . . . . . 65

Figura 2.17 -Fluxograma típico de um algoritmo genético. . . . . . . . . . . 74

Figura 2.18 -Aumento de mortalidade em função da idade no modelo Penna. 79

Figura 5.1 - Modelo Inicial. Curvas de sobrevida das 16 simulações realizadas. . . . . . . . . . . . . . . . . 100

Figura 5.2 - Modelo Inicial. Variação da mortalidade total $(\mu)$ por ciclo em três populações submetidas à mesma probabilidade extrínseca de morte $\mu_{e}=0,0125$ por ciclo. . . . . . . . . . . . . 101

Figura 5.3 - Modelo Inicial. Variação da mortalidade total $(\mu)$ por ciclo em três populações submetidas à mesma probabilidade extrínseca de morte $\mu_{e}=0,2$ por ciclo. . . . . . . . . . . . . 102

Figura 5.4 - Curva de evolução das MIMED para $\mu_{i}=0,1$ e $\mu_{e}$ variando de 0,025 a 0,2 por ciclo. População 1024. Modelo Inicial. . . . . . 103

Figura 5.5 - Modelo Inicial. Valores de MIMED atingidos em $10^{6}$ ciclos em função de $\mu_{e} . \ldots \ldots$. . . . . . . . . . . . . . . . . . . 104

Figura 5.6 - Curva de evolução das MIMED ao longo da evolução para diferentes combinações de $\mu_{e}$ e $\mu_{i}$. Modelo Final. $10^{6}$ ciclos. . 107 
Figura 5.7 - Distribuição etária das idades de manifestação ao final das simulações, para diferentes combinações de $\mu_{e}$ e $\mu_{i}$. Modelo Final. $10^{5}$ ciclos. . . . . . . . . . . . . . . . 108

Figura 5.8 - Tamanho populacional efetivo $\left(N_{e}\right)$ para diferentes combinações de $\mu_{e}$ e $\mu_{i}$, ao longo de $10^{5}$ ciclos. Modelo Final. . . . . . 109

Figura 5.9 - Número de genótipos ao longo da evolução. Modelo final. $10^{5}$ ciclos. . . . . . . . . . . . . . . 110

Figura B.1 - O famoso diagrama da evolução humana e a falácia do hindsight.155

Figura B.2 - Evolução com fixação por deriva genética aleatória. . . . . . . 158

Figura B.3 - Variação na frequência alélica por deriva genética aleatória em

2 tamanhos populacionais. . . . . . . . . . . . . 160 


\section{Lista de Abreviaturas}

MRDT

MIMED

$M E$

$M I$
Mortality Rate Doubling Time, ou Tempo de Duplicação da Mortalidade

Média das idades de manifestação do efeito deletério

Mortalidade Extrínseca

Mortalidade Intrínseca 


\section{Lista de Símbolos}

$v_{i} \quad$ Valor Reprodutivo na idade $i$ (Fisher)

$\ell_{i} \quad$ Probabilidade de sobrevivência da idade 0 à idade $i$

$m_{i} \quad$ Número médio de descendentes produzidos por um indíviduo a partir da idade $i$

$R \quad$ Taxa reprodutiva líquida de uma população

$T$ Idade média de reprodução dos indivíduos em uma população

$N \quad$ Tamanho de uma população em número de indivíduos

$N_{e} \quad$ Tamanho populacional efetivo em número de indivíduos

$N_{e(a)}$ Tamanho populacional efetivo em número de indivíduos, para as idades $>a$

p $\quad$ Frequência de um alelo em uma população

W Aptidão

$W_{a b s}$ Aptidão absoluta de um genótipo ou fenótipo

$W_{\text {rel }}$ Aptidão relativa entre diferentes genótipos ou fenótipos

$S \quad$ Coeficiente Seletivo de um gene (Wright)

$S_{n} \quad$ Cada um dos $n$ efeitos seletivos de um gene pleiotrópico (Wright) 
$m_{n} \quad$ Magnitude de cada um de $n$ efeitos seletivos de um gene pleiotrópico (Williams)

$p_{n} \quad$ Proporção da probabilidade reprodutiva de cada um de $n$ efeitos seletivos de um gene pleiotrópico (Williams)

$\mu_{e} \quad$ Mortalidade Extrínseca, expressa em probabilidade de morte por ciclo de simulação

$\mu_{i} \quad$ Mortalidade Intrínseca, expressa em probabilidade de morte por ciclo de simulação

$\lambda \quad$ Taxa de mutação 
Esta tese está de acordo com as seguintes normas, em vigor no momento desta publicação:

Referências: adaptado de International Committee of Medical Journals Editors (Vancouver).

Universidade de São Paulo. Faculdade de Medicina. Divisão de Biblioteca e Documentação. Guia de apresentação de dissertações, teses e monografias. Elaborado por Anneliese Carneiro da Cunha, Maria Julia de A. L. Freddi, Maria F. Crestana, Marinalva de Souza Aragão, Suely Campos Cardoso, Valéria Vilhena. 3a ed. São Paulo: Divisão de Biblioteca e Documentação; 2011.

Abreviaturas dos títulos dos periódicos de acordo com List of Journals Indexed in Index Medicus. 


\section{Sumário}

\section{Resumo}

Abstract

\section{Lista de Figuras}

Lista de abreviaturas

Lista de símbolos

1.2 Por que senescemos? Um problema evolutivo. . . . . . . . . . . . . 2

1.2.1 A senescência "para o bem da espécie" . . . . . . . . . . . . 3

1.3 Do estudo proposto . . . . . . . . . . . . . . . 6

$\begin{array}{lll}2 & \text { Revisão da literatura } & 7\end{array}$

2.1 Definições em biogerontologia . . . . . . . . . . . . . . 8

2.1.1 O que se entende por envelhecimento? . . . . . . . . . 8

2.1.2 Como delimitar senescência e senilidade? . . . . . . . . . . . 9

2.1.3 Medidas de duração da vida: expectativa de vida e longevidade 12

2.1.4 Senescência fisiológica e senescência demográfica . . . . . . . . 12

2.2 A senescência demográfica sob a lei de Gompertz-Makeham . . . . . . 13

2.3 As Teorias da Senescência . . . . . . . . . . . . . . . . 22

2.3.1 Classificando as teorias da senescência . . . . . . . . . . 23

2.3.2 A teoria da taxa de vida . . . . . . . . . . . . . . 24 
2.3.3 As teorias mecanicistas da senescência . . . . . . . . . . . 28

2.4 As origens evolutivas da senescência . . . . . . . . . . . . . . . . 36

2.4.1 A força da Seleção Natural cai com a idade . . . . . . . . . . 38

2.4.2 Haldane e a doença de Huntington . . . . . . . . . . . . . . 40

2.5 A Teoria do Acúmulo de Mutações de Medawar . . . . . . . . . . . . 41

2.6 A Teoria da Pleiotropia Antagônica de Williams . . . . . . . . . . . . 43

2.7 A Teoria do Soma Descartável de Kirkwood . . . . . . . . . . . . . . 48

2.8 As teorias da senescência hoje . . . . . . . . . . . . . . . . 50

2.9 Estudando a evolução através de simulações matemáticas e computacionais . . . . . . . . . . . . . . . . . . 6 62

2.9.1 Modelos computacionais no estudo evolutivo . . . . . . . . 72

2.9.2 Simulações computacionais e a evolução da senescência . . . . 78

3 Objetivos $\quad 83$

3.1 Objetivos Gerais . . . . . . . . . . . . . . . . 84

3.2 Objetivos Específicos . . . . . . . . . . . . . . . 84

4 Métodos $\quad 85$

4.1 Construindo o Modelo Inicial _ . . . . . . . . . . . . . . . . 86

4.1 .1 Os experimentos . . . . . . . . . . . . . . . . 90

4.1.2 Modelo Final: Otimizando o algoritmo . . . . . . . . . . . . 92

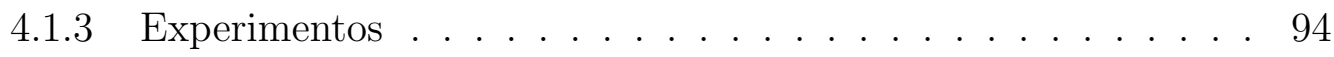


5.1 Modelo Inicial . . . . . . . . . . . . . . . . . . . . . . . . 97

5.1.1 A mortalidade caiu ao longo do processo . . . . . . . . . . . 97

5.1.2 Efeito da mortalidade extrínseca . . . . . . . . . . . . . 97

5.1.3 Efeito da mortalidade intrínseca . . . . . . . . . . . . . . 98

5.1.4 O efeito combinado das mortalidades . . . . . . . . . . . 98

5.2 Modelo Final . . . . . . . . . . . . . . . . . . . . . . . . . 98

5.2.1 Mudanças na estrutura etária . . . . . . . . . . . . . . . 99

5.2.2 Evolução das distribuições de alelos por idade de manifestação 99

5.2.3 Variações no tamanho populacional efetivo $\left(N_{e}\right) \ldots 101$

5.2.4 O Efeito da Mortalidade Extrínseca . . . . . . . . . . . . 105

5.2 .5 O Efeito da Mortalidade Intrínseca . . . . . . . . . . . 105

6 Discussão 111

6.1 Modelo Inicial . . . . . . . . . . . . . . . . . . . . . . . . . . . 112

6.2 O Modelo Final . . . . . . . . . . . . . . . . . . . . . . . 112

6.2.1 Evolução de uma característica deletéria em um locus essencial 113

6.2.2 Tamanho populacional efetivo $\left(N_{e}\right)$ e força da seleção . . . . . 118

6.2.3 Evolução das distribuições de alelos por idade de manifestação 121

6.3 O Efeito da Mortalidade Extrínseca . . . . . . . . . . . . . . . 127

6.4 O Efeito da Mortalidade Intrínseca . . . . . . . . . . . . . . 129 
6.5 Considerações finais . . . . . . . . . . . . . . . . . . . . 130

7 Conclusões

132

7.1 Objetivos Gerais . . . . . . . . . . . . . . . 133

7.2 Objetivos Específicos . . . . . . . . . . . . . . . . . 134

Apêndice A - Artigo Publicado

B.1 Breve histórico . . . . . . . . . . . . . . . . . . 145

B.1.0.2 Malthus e a "luta pela vida" . . . . . . . . . . 145

B.1.0.3 Evolução Darwiniana Clássica . . . . . . . . . . . . . 146

B.1.0.4 A moderna síntese evolutiva . . . . . . . . . . . . 147

B.1.1 Seleção natural . . . . . . . . . . . . . . . . . . . . . . . . . 148

B.1.1.1 Como se mede a aptidão ? . . . . . . . . . . . . . 149

B.1.1.2 Seleção em haplóides em gerações discretas . . . . . 152

B.1.1.3 Seleção em haplóides em gerações contínuas ... . 154

B.1.2 Evolução e Adaptação . . . . . . . . . . . . . . . . . . . . . . 154

B.1.3 A Deriva genética aleatória e a Teoria Neutra da Evolução . 156

B.1.3.1 O Modelo Populacional de Wright-Fisher . . . . . . . 160

B.1.4 Tamanho populacional efetivo $\left(N_{e}\right) \ldots \ldots$. . . . . . 162

B.1.4.1 Variações no tamanho populacional $(N)$. . . . . . 163 
B.1.4.2 Gerações contínuas e estrutura etária . . . . . . . . 164

B.1.5 O Modelo de Alelos Infinitos . . . . . . . . . . . . . . . 165

B.1.6 Equilíbrio Seleção - Mutação . . . . . . . . . . . . . . . . . 167

B.1.7 O efeito conjunto de Seleção e Deriva . . . . . . . . . . . . . 168

\section{Referências}


1 Introdução 


\section{$1.1 \quad$ Memento mori}

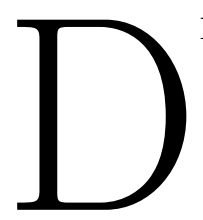

ESDE a Antiguidade os seres humanos sabem que sofrerão mudanças ad-

versas pari passu com a passagem do tempo (Hall, 2000). Na mais antiga referência de que se tem notícia sobre estas mudanças, Ptah-hotep, um egípcio que viveu no século XXIV a.C., diz: "a idade avançada desce sobre mim (...) os olhos estão pequenos; as orelhas, surdas; a energia, diminuída (Lichtheim, 1973)."

A fertilidade e a força física caem; nossa fragilidade, aumenta. Estas mudanças progressivas estão relacionadas a um processo que hoje chamamos senescência (Medawar, 1946).

Comfort acredita que tomamos consciência da existência deste processo desde muito jovens. "Qualquer criança desde a emergência da linguagem provavelmente perguntou 'Por que aquele homem morreu?' e foi-lhe contado que 'Ele morreu porque era velho"' (Comfort, 1956).

De fato, quantas vezes ao longo de nossas vidas não fazemos ou respondemos a mesma pergunta? O processo de senescência nos coloca diante de nossas próprias fragilidades, como antigamente o servo fazia com o general triunfante:

- Memento mori.

\subsection{Por que senescemos? Um problema evolutivo.}

Os aspectos acima mencionados relacionam-se a duas perguntas fundamentais da gerontologia: "Por que senescemos?" e "Como senescemos?".

A própria existência do processo de senescência impôs à biologia evolutiva aquilo que já se chamou de paradoxo da senescência: por um lado, esta é um pro- 
cesso biológico nitidamente deletério para o indivíduo; por outro não apenas não foi eliminada pela Seleção Natural, mas é comum entre animais filogeneticamente distintos, tendo sido descrita em vermes, artrópodes, peixes, répteis, aves e mamíferos (Austad, 1997b).

Este problema evolutivo não passou despercebido por Darwin. Na sexta edição de "A origem das espécies" (1872), ele escreve:

A critic has lately insisted, with some parade of mathematical accuracy, that longevity is a great advantage to all species, so that he who believes in natural selection "must arrange his genealogical tree" in such a manner that all the descendants have longer lives than their progenitors! Cannot our critic conceive that a biennial plant or one of the lower animals might range into a cold climate and perish there every winter; and yet, owing to advantages gained through natural selection, survive from year to year by means of its seeds or ova? (...) And these conditions have, it is probable, been largely determined through natural selection.

Para Darwin, portanto, a senescência não parecia um paradoxo; fica claro, no entanto, que ele não considerou no raciocínio acima a possibilidade de que a senescência pudesse prejudicar o desempenho reprodutivo de seu portador e, por isto, estar sujeita a eliminação por seleção natural.

Caberia a August Weismann, em 1891, a primeira tentativa de formular um mecanismo que compatibilizasse a evolução da senescência com a evolução darwiniana (Weismann, 1889).

\subsubsection{A senescência "para o bem da espécie"}

Para Weismann, um mecanismo operando para o bem das espécies explicaria a evolução da senescência. Indivíduos mais velhos, Weismann afirma 1889, "não são somente sem valor para a espécie, mas são até mesmo danosos, pois tomam o lugar daqueles que são sadios" (grifo meu). 
A senescência teria surgido como qualquer outra adaptação: através de variações aleatórias sob a força de seleção. O surgimento de novo da senescência em uma população resultaria no aumento da mortalidade dos exemplares mais idosos. Estes, mais raros na população, diminuiriam sua participação no consumo de recursos ambientais, os quais ficariam mais disponíveis aos mais jovens. Por possuírem maior potencial reprodutivo, exemplares mais jovens transformariam tais recursos em uma prole maior do que teriam feito os indivíduos idosos. Weismann vai além: a otimização evolutiva deste mecanismo seria a mínima duração da vida necessária para que o desempenho reprodutivo de uma população mantivesse sua estabilidade (Weismann, 1889).

Weismann também era autor da teoria do germe-plasma. Esta essencialmente postulava a separação nos "organismos superiores" entre células de linhagens germinativa e somática: células germinativas dariam origem a células germinativas e a células somáticas. Estas somente dariam origem a novas células somáticas no mesmo indivíduo. Para Weismann, esta outra teoria fornecia o mecanismo biológico sobre o qual sua teoria da senescência poderia operar. Em síntese, Weismann propôs que as células somáticas não evoluíram capacidade de manter a divisão celular por longos ciclos.

Embora engenhosa, a teoria da senescência para o "bem da espécie" sustentouse sobre três frágeis pressupostos: a necessidade de um processo hoje conhecido como seleção de grupo, a senescência causada pela senescência e a pressão seletiva por competição entre as frações idosa e jovem de uma população não senescente.

O primeiro pressuposto foi considerado falso por não se conciliar com o modelo evolutivo de Darwin, que prevê a seleção de variações que confiram vantagens para os indivíduos portadores e sua prole, mas não diretamente para a espé- 
cie (Rice, 2007). De fato, excetuando-se aquelas que pudessem ser explicadas por seleção sexual, um conceito formulado pelo próprio Darwin (1871), a evolução de características claramente deletérias para o indivíduo não era explicável na época de Weismann ${ }^{1}$, pois demandariam a seleção de grupo para que fossem consideradas um bem para a espécie (Austad, 1997b).

A segunda premissa é um argumento circular, pois afirma que indivíduos mais velhos não teriam valor para a espécie porque gerariam menos descendentes que indivíduos jovens para um mesmo consumo energético e, consequentemente sua concorrência por recursos ambientais seria prejudicial à fertilidade da população. Para que isto fosse verdade, indivíduos mais velhos teriam de ser, também, menos férteis ou menos sadios como o pŕoprio Weismann coloca. Portanto, já são senescentes. Assim, este argumento explica a origem da senescência como consequência de sua existência (Comfort, 1956).

Embora a inexatidão da terceira premissa somente seria demonstrada por Medawar (1952), Weismann reconheceu não não conseguir conciliar sua primeira premissa com o modelo darwiniano, o que o levou a abandonar sua teoria (Weismann, 1892). Até a segunda metade do século passado, a origem evolutiva da senescência mantinha-se, nas palavras de Medawar, um "problema não solucionado pela biologia" (Medawar, 1952).

\footnotetext{
${ }^{1}$ A evolução dos insetos sociais, como as abelhas, em que uma família de operárias estéreis serve a uma única fêmea e um pequeno grupo de machos férteis, bem como dos comportamentos altruístas, como animais sentinelas que emitem alarmes sonoros diante da aproximação de um predador, chamando a atenção do predador para si mas salvando vários membros de sua espécie foi finalmente compatibilizada com a teoria evolutiva por Hamilton (1964): este formulou a idéia, ainda aceita, de que genes deletérios para seus portadores são favoravelmente selecionados desde que os benefícios que causam para portadores do mesmo gene superem (em termos de número de descendentes) o impacto deletério que causam.
} 


\subsection{Do estudo proposto}

O presente estudo trata do desenvolvimemto de um ambiente computacional que permita a simulação das condições evolutivas para o surgimento e manutenção da senescência.

Pretende-se que o modelo a ser desenvolvido seja o mais simples possível, encontrando o menor número de variáveis que sejam essenciais para capturar os mecanismos de instalação e manutenção da senescência em uma população. Este tipo de modelo tem, também, a vantagem de permitir condições controladas para o teste de hipóteses e a condução de experimentos em tempos consideravelmente mais curtos do que suas contrapartidas biológicas.

Propõe-se a construção e utilização de um ambiente de simulações computacionais que ajude a investigar os papéis da mortalidade ambiental, da mortalidade causada por um suposto gene da senescência e da deriva genética aleatória sobre dinâmicas evolutivas quase neutras. 
2 Revisão da literatura 


\subsection{Definições em biogerontologia}

\subsubsection{O que se entende por envelhecimento?}

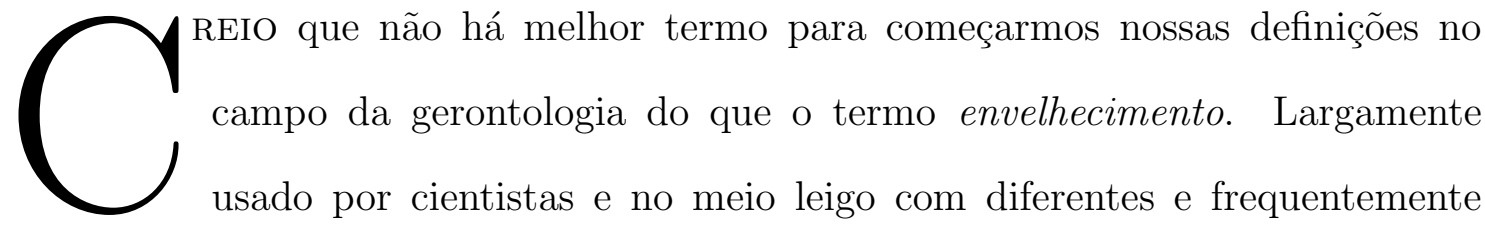
vagos significados (Rose, 1991), "envelhecimento" é "o ato ou efeito de envelhecer"; "envelhecer", por sua vez, significa "tornar velho, avelhentar; fazer que pareça velho; tornar-se usado ou inútil"1. O significado do inglês aging é análogo².

Comumente chamamos de envelhecimento três processos distintos, que envolvem:

1. incremento etário em função do tempo (que é o envelhecimento propriamente dito);

2. perda de funções vitais ou aumento de mortalidade acompanhando o envelhecimento, causados por processos patológicos (chamada de senilidade);

3. perda de funções vitais ou aumento de mortalidade acompanhando o envelhecimento, causados por processos fisiológicos.

Esta última é a senescência (Busse, 1969).

\subsubsection{O uso indiscriminado de envelhecimento e aging}

Fica claro que o uso do termo envelhecimento em gerontologia é impreciso, pois não denota a qual dos três fenômenos se refere. Ainda assim, a maioria dos

${ }^{1}$ Michaelis Moderno Dicionário Da Língua Portuguesa - Walter Weiszflog. Editora Melhoramentos, São Paulo, 1998.

2 The Merriam-Webster Dictionary, Merriam-Webster, 2005) 
gerontólogos ainda utiliza o termo envelhecimento (ou aging) para designar o processo de senescência (ou senescence) com maior frequência do que estes últimos termos. Assim, é impossível fazer uma pesquisa confiável sobre a senescência em bases de dados internacionais sem incluir os termos aging / ageing. Dificultando ainda mais, sob estes termos também achamos muita literatura sobre a senilidade ou seu equivalente em inglês, senility (Rose, 1991).

Há um segundo problema terminológico neste campo. O termo senescence tem sido largamente usado na literatura em inglês para denotar a "senescência" que flores e folhas de um vegetal sofrem em seu ciclo normal. Para o estudioso da senescência biológica que escreve naquele idioma, ater-se aos termos corretos impõe os riscos de não detectar trabalhos importantes e de não ser lido por outros pesquisadores, os quais, cientes dos termos mais correntes nesta área, poderiam deixar buscar pelo termo senescence na literatura (Rose, 1991).

Neste texto, no entanto, o termo envelhecimento será utilizado somente em citações ou quando for necessário para denotar o exclusivamente o incremento etário resultante da passagem do tempo.

\subsubsection{Como delimitar senescência e senilidade?}

Como mencionado, senescência senilidade têm sido considerados processos distintos. Para a prática médica, saber o que diferencia ambos é tão importante que tivemos recentemente a oportunidade de ecoar as seguintes definições em um Tratado de Clínica Médica (Jacob Filho; Monaco, 2009):

Senescência ou envelhecimento fisiológico é o nome que se dá ao processo normal de envelhecimento e ao conjunto de alterações inexoráveis determinadas por esse processo. A senescência implica em perda de reserva funcional sem acarretar per se em insuficiência mesmo em idades muito avançadas; Senilidade ou envelheci- 
mento patológico é o termo que se dá às alterações ou aos processos alheios ao envelhecimento fisiológico e determinados por doenças e maus hábitos de vida, como o sedentarismo ou o tabagismo. Esses agravos, associados à diminuição de reserva funcional esperada em idosos, poderão resultar em situações de insuficiência de órgãos ou funções, bem como na incapacidade para as atividades da vida diária, dependência e desautonomia.

Sabemos que a senescência acarreta insuficiências funcionais em idades muito avançadas (Kuchel, 2009). O que justifica esta meia-verdade é enfatizar para uma audiência de não especialistas que a senilidade hoje é a grande causa de perdas funcionais precoces (veja a Figura 2.1). Lidar com as limitações que resultam de tais perdas em pacientes nas suas quinta ou sexta décadas é uma rotina diária dos profissionais de saúde. Entre estes e o público geral ainda existe a noção de que tais limitações são "normais do envelhecimento". Não são. De fato, Jeanne Calment, a pessoa mais longeva de que se tem notícia, experimentou bons níveis de funcionalidade até próximo de seus 120 anos (Robine; Allen, 1999). Por pensarem de forma errônea, pacientes e profissionais arriscam-se à conformidade diante de limitações preveníveis e potencialmente reversíveis.

À biogerontologia, no entanto, interessa um tratamento mais preciso dos termos senescência e senilidade. Disto dependem o desenho de estudos para investigar suas bases e a forma como interpretaremos nossos achados (Masoro, 2006).

Comfort (1956) define a senescência como um processo de crescente vulnerabilidade, enfatizando que a senescência pode ser medida através das crescentes probabilidades de morte com aumento na idade cronológica. A esta definição Medawar adiciona a progressiva perda da fertilidade com aumento etário (Medawar, 1955). Embora historicamente não tenha havido uma definição exata e consensual de senescência, esta tem sido consensualmente considerada como um processo natural e intrínseco às espécies senescentes, ou seja, partilhado por todos os seus 
membros (Kirkwood; Austad, 2000).

Aceita-se que o aumento na probabilidade de morrer em um animal que senesce esteja ligado à progressiva diminuição de suas reservas funcionais (estas lhes conferem capacidade de lidar com sobrecargas funcionais geradas, por exemplo, por doenças) (Shock, 1967). Isto explica por que, diante da mesma sobrecarga funcional, a probabilidade de morte em humanos idosos é maior do que em jovens (Kuchel, 2009).

Este modelo de senescência entrou em crise durante a década de 1960. Com o progresso do conhecimento gerontológico e geriátrico, ficava claro que parte dos fenômenos até então considerados próprios da senescência não era biologicamente intrínseca ao ser humano e a outras espécies em estudo. Estas espécies mostravam aumento no incremento da mortalidade idade-específica sob influências extrínsecas, como ambientes hostis, maus hábitos de saúde e doenças. Esta crise ficou conhecida como o paradoxo da intrinsicalidade (Masoro, 2006).

O paradoxo da intrinsicalidade foi finalmente solucionado com a separação das causas de incremento na mortalidade em dois grupos. Dentre tais causas, apenas os fenômenos e processos biológicos intrínsecos a uma espécie continuariam a fazer parte de seu envelhecimento normal ou primário, que é a senescência. Fenômenos e processos biológicos não-intrínsecos a toda uma espécie passaram a fazer parte de um envelhecimento patológico ou secundário ou, também, senilidade (Busse, 1969).

Na mesma linha, Fries propõe o conceito de morte natural, ou "morte na ausência de doenças" (Fries, 1980). Associando estes termos, Shock propõe que o envelhecimento normal, ou a senescência, seria "o envelhecimento na ausência de doenças" (Shock, 1984). 


\subsubsection{Medidas de duração da vida: expectativa de vida e longevidade}

Alguns termos relacionados à duração da vida são bastante utilizados em senescência; nesta tese utilizaremos as definições que se seguem (Fletcher, 2006).

Expectativa de vida em uma dada idade é tempo médio que um grupo de indivíduos de mesma idade pode esperar viver a partir desta idade. É comum o cálculo da expectativa de vida ao nascer, que expressa o tempo médio que um grupo de indivíduos nascidos no mesmo período pode esperar viver. A expectativa de vida mediana é a mediana da curva de distribuição etária de uma população, ou seja, a idade em que se espera que metade dos indivíduos nascidos no mesmo período já tenham morrido. A expectativa máxima de vida é o máximo período de tempo que um organismo de uma dada espécie já viveu. Por isto, é normalmente computada através da máxima longevidade observada para um membro de uma espécie. Em contraste, a longevidade de uma espécie é o período médio de tempo que os membros de uma espécie vivem do nascimento à morte, sob condições ideais. Por fim, a longevidade de um indivíduo é, simplesmente, o período de tempo que este viveu, do nascimento à morte. Vale notar que, diferentemente da longevidade (que pressupõe condições ideais), as expectativas de vida são calculadas com base nas mortalidades medidas; portanto, sua capacidade de predição depende da manutenção das mesmas taxas de mortalidade.

\subsubsection{Senescência fisiológica e senescência demográfica}

Embora usualmente considerados em conjunto, podemos aludir às causas e efeitos da senescência sobre os indivíduos (senescência fisiológica), ou sobre as curvas de mortalidade e sobrevivência populacionais (senescência demográfica ou 
atuarial) (Masoro; Austad, 2006).

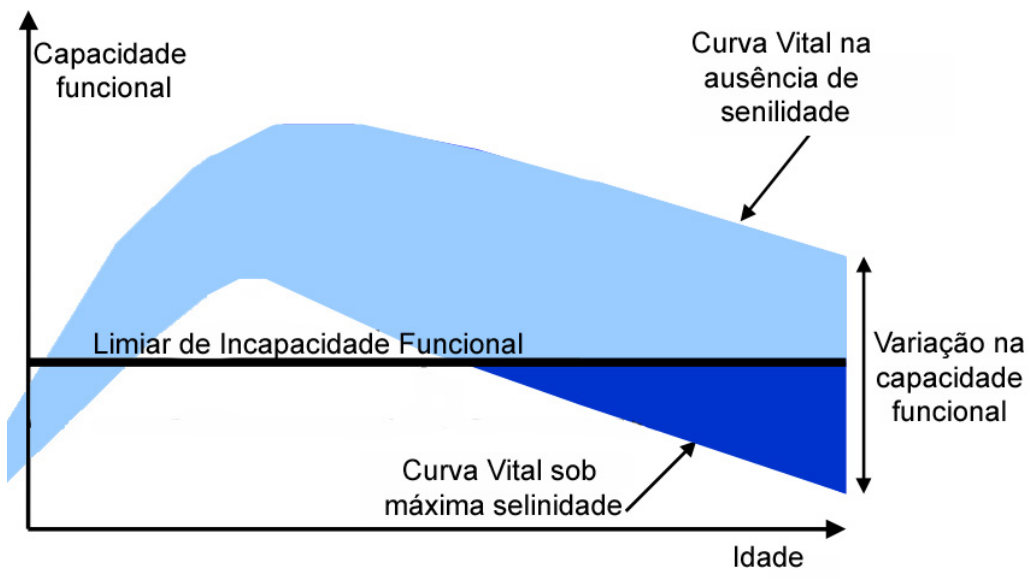

Figura 2.1 - Evolução da capacidade funcional humana ao longo da vida. Dominada pelo processo de desenvolvimento, a primeira década de vida caracteriza-se por um aumento de capacidade funcional. A partir da segunda década, os processos de desenvolvimento começam a perder dominância sobre o processo de senescência. Tipicamente, ao final da terceira década, a capacidade funcional humana atingiu seu máximo. A partir deste momento, o processo de senescência é nitidamente sentido como uma progressiva queda na capacidade funcional. A borda superior da curva representa indivíduos cuja senescência acompanhou-se de pouca ou nenhuma senilidade; estes caem abaixo do limiar mínimo de capacidade funcional em idades muito avançadas. A borda inferior da curva representa indivíduos cuja senescência acompanhou-se de máxima senilidade; estes caem abaixo do limiar mínimo de capacidade funcional em idades muito precoces. Adaptado de Stein e

Moritz (1999)

\subsection{A senescência demográfica sob a lei de Gompertz- Makeham}

Benjamin Gompertz, matemático e cientista atuarial britânico trabalhava para aprimorar o conhecimento das companhias de seguro sobre a mortalidade humana em distintas faixas etárias quando realizou comparações em tábuas de mortalidade de diferentes países então disponíveis. Tais comparações fizeram-no notar que a mortalidade humana parecia dobrar com incrementos etários fixos (Gompertz, 
1825). Formulou, então, a equação que descreve seu achado:

$$
m_{(t)}=A e^{G t}
$$

onde

$A$ é a vulnerabilidade básica da população;

$G$ é o coeficiente de Gompertz, para uma aceleração monotônica da mortalidade;

$t$ é a idade associada à mortalidade medida;

$m_{(t)}$ é a mortalidade para a idade $t$.

Gompertz estava ciente de que nossa espécie exibia taxas de mortalidade inicialmente mais altas e descrescentes em função da idade, atingindo um mínimo por volta dos 12 anos É a partir desta idade que seu modelo passa a descrever as taxas de mortalidade da espécie. Como o foco de Gompertz era a predição das taxas de mortalidade ao longo da vida, ele apenas toma o cuidado de calcular o coeficiente $A$ na idade de mortalidade mínima (Gompertz, 1825).

Este componente mínimo da mortalidade refletiria, assim, a vulnerabilidade intrínseca; esta seria a capacidade básica de proteção de um organismo (Kowald, 2002). Finalmente, $G$ refletiria a senescência em si, ou o grau de aceleração da mortalidade (Finch; Pike, 1996).

A partir da determinação de $G$ pelas tábuas de mortalidade, pode-se calcular o intervalo de tempo em que a mortalidade dobra a partir de qualquer idade após a mortalidade mínima (Finch; Pike, 1996). Isto pode ser feito a partir da mesma equação de Gompertz, dado que, para

$$
m_{(t)}=A e^{G t}
$$

então

$$
m_{(2 t)}=A e^{2 G t}
$$


Se

$$
m_{(2 t)}=2 m_{(t)}
$$

então

$$
A e^{2 G t}=2 A e^{G t}
$$

simplificando para $t$, temos que

$$
\begin{gathered}
e^{2 G t}=2 e^{G t} \rightarrow e^{G t} \cdot e^{G t}=2 e^{G t} \rightarrow e^{G t}=2 \\
\therefore G t=\ln 2 \quad \therefore t=M R D T=\frac{\ln 2}{G}=0,693 / G
\end{gathered}
$$

onde MRDT é o Mortality Rate Doubling Time ou Intervalo de Duplicação da Taxa de Mortalidade. O MRDT foi calculado por Gompertz para as populações que estudou, como sendo cerca de 8,5 anos (Gompertz, 1825). Isto caracteriza de forma acurada o aumento de mortalidade causado pela senescência humana em diferentes populações pelo menos entre os 30 e 70 anos de idade (Finch; Pike, 1996).

Para ilustrar a importância do achado de Gompertz, podemos construir a curva de mortalidade de uma população humana real. A Figura 2.2) representa a mortalidade da população americana medida em 2007, cujos dados encontram-se disponíveis eletronicamente (CDC, 2010)). O comportamento exponencial da mortalidade, nesta amostra, entre as idades de 30 e 90 anos (Figura 2.3, com os pontos destacados em vermelho) fica evidente ao representarmos os mesmos dados em escala semi-logarítmica (com a idade expressa em escala natural e a mortalidade em escala logarítmica). Esta forma de plotagem semi-log dos gráficos de mortalidade, conhecida como gráfico de Gompertz, tornou-se comum em ciência atuarial, pois permite visualizar rapidamente se as taxas de mortalidade crescem de forma exponencial como descrito por Gompertz (Gavrilov; Gavrilova, 2006). 


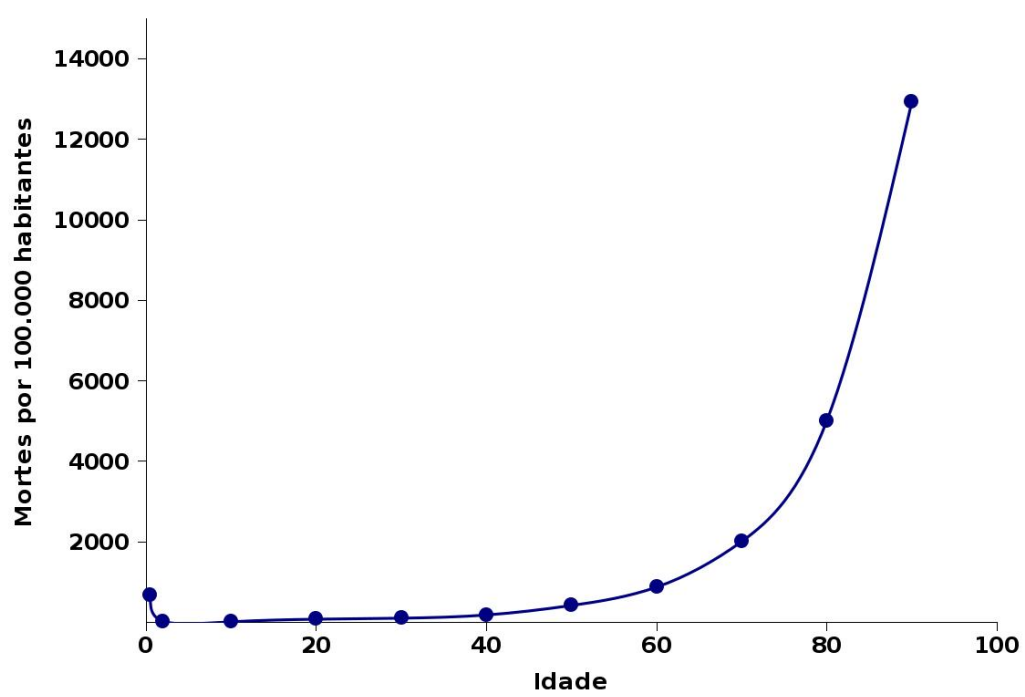

Figura 2.2 - Mortalidade da população americana em 2007 (montada a partir dos dados em CDC (2010)).

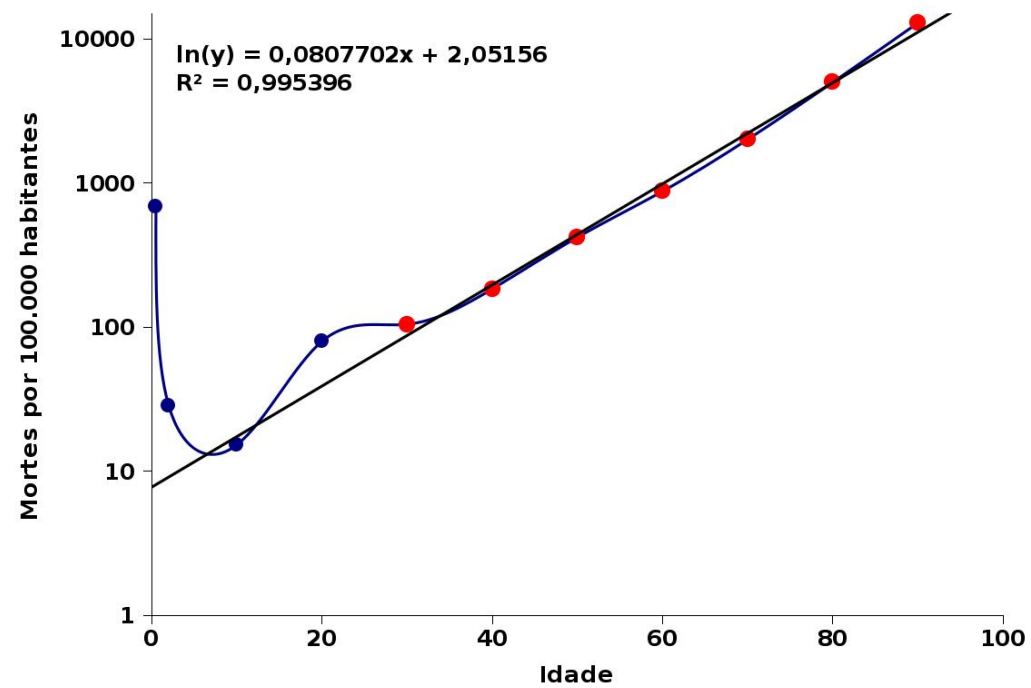

Figura 2.3 - Mortalidade em 2007 da população americana normalizada para uma população de 100.000 habitantes de cada grupo etário, em gráfico semi-log. Plotar as mortalidades em escala logarítmica facilita a visualização dos menores valores, bem como do comportamento exponencial apresentado a partir dos 30 anos de idade (pontos vermelhos). (montada a partir dos dados em CDC (2010)).

Ainda no exemplo considerado na Figura 2.3, podemos obter através de uma planilha eletrônica a equação que descreve a reta média para os pontos destacados 
em vermelho. A equação obtida é

$$
\ln (y)=0,0807702 x+2,05156
$$

com coeficiente de determinação $R^{2}=0,995396$ e onde $y$ é a mortalidade relacionada a $x$, ou a idade em anos. Tais termos são equivalentes na equação 2.1 aos termos $m_{(t)}$ e $t$.

A equação da reta também pode ser expressa por

$$
\ln \left(m_{(t)}\right)=0,0807702 t+2,05156
$$

por sua vez, a equação 2.1 também pode ser escrita na mesma forma:

$$
\ln \left(m_{(t)}\right)=G t+\ln (A)
$$

substituindo entre as duas equações, calculamos $A$ :

$$
\ln (A)=2,05156 \quad \therefore A=e^{2,05156} \rightarrow A=7,78
$$

finalmente, temos que

$$
m_{(t)}=7,78 e^{0,0807702 t}
$$

que são os mesmos dados expressos na equação inicial 2.1, de Gompertz. De posse do valor de $G=0,0807702$, podemos estimar o MRDT em anos através da Equação 2.1: $M R D T=0,693 / 0,0807702=8,58$ anos, surpreendentemente próximo à estimativa original de Gompertz, medida mais de 150 anos antes.

O resultado surpreende porque, embora a expectativa de vida ao nascer tenha aumentado muito desde então (de 39,92 anos em 1826 para 73,5 anos em 1980 na Inglaterra de Gompertz (Floud; Harris, 1996) e de 47,3 anos em 1900 para 77,3 anos em 2002 nos Estados Unidos (Statistics, 2010)), o MRDT tem-se 
mantido bastante estável na história, por volta de 8 anos em diferentes populações e épocas (Finch; Pike; Witten, 1990; Kowald, 2002).

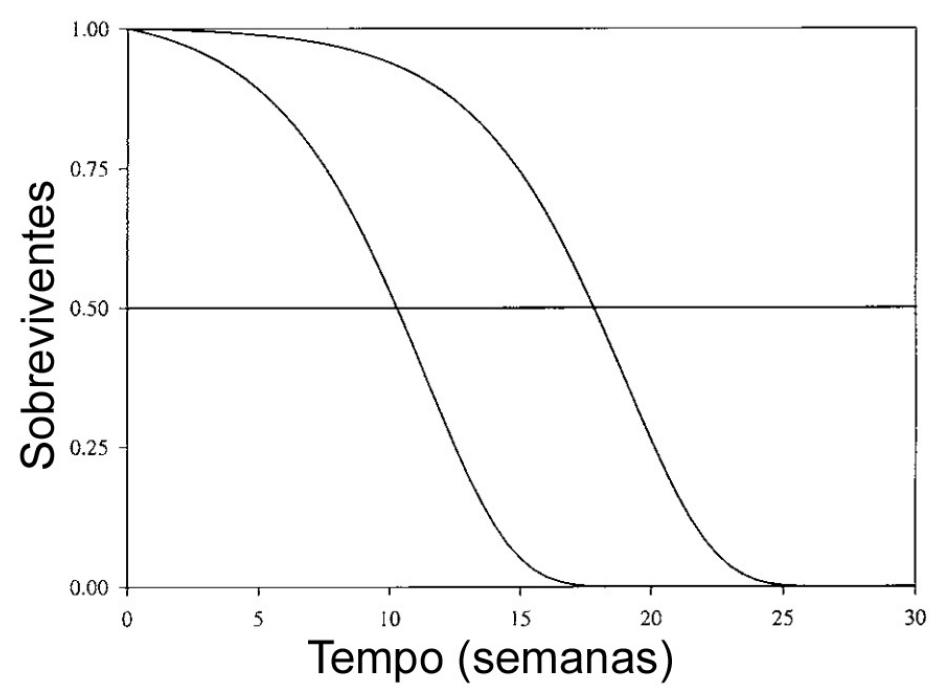

Figura 2.4 - Curvas de sobrevivência para duas populações com diferentes mortalidades distintas mas mesma velocidade de senescência. Os coeficientes idadeindependente da mortalidade $(A)$ são 0,01 e 0,001 , enquanto que o coeficiente idade-dependente é igual para ambos $(G=0,3)$. Apesar da nítida diferença em sobrevivência, ambas as populações senescem com a mesma velocidade, dobrando de mortalidade com o mesmo MRDT. Extraído de (Kowald, 2002)

Sabe-se hoje que o MRDT constante é característico para várias espécies estudadas e acredita-se que isto refletir a velocidade de senescência de cada espécie (Bronikowski et al., 2002). Por este conceito, esta constância no valor do MRDT não é de fato surpreendente. O enorme aumento na expectativa de vida em todo o mundo, com o inédito efeito do envelhecimento populacional, é explicado por uma queda global na mortalidade associada a avanços em saneamento básico, nutrição, medicina preventiva, melhores condições de trabalho e combate às doenças infecciosas. No entanto estas melhorias impactam não na biologia da senescência, mas na mortalidade extrínseca da população humana, notadamente na mortalidade infantil (aumentando o número pessoas que sobrevivem à infância) (Beemer; Anderton; Leonard, 2005). Com efeito, a Figura 2.5 nos mostra claramente o impacto da redução da mortalidade infantil nos Estaos Unidos do início do século passado sobre 
a distribuição etária de sua população ao logo do mesmo século.

Para uma população descrita pela Equação de Gompertz, o impacto destas mudanças é observável sobre a vulnerabilidade basal $(A)$. Pode-se compreender sua diminuição em função da queda nas causas extrínsecas de morte. Definida a mortalidade extrínseca (ME) como a soma das causas de morte externas à biologia a indivíduo (Medawar, 1952), ambientes protetores ou nocivos implicarão em maior ou menor efeito da vulnerabilidade basal sobre a mortalidade. Diferente do efeito de uma alteração em $G$, variações em $A$ não alteram o MRDT. Isto é exemplificado na Figura 2.4.

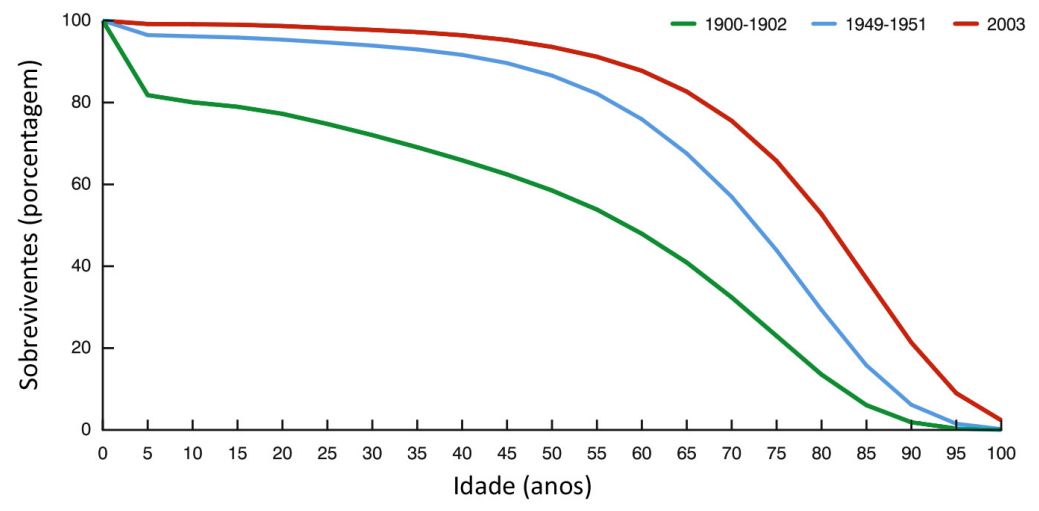

Figura 2.5 - Curvas de sobrevivência da população americana no início e na metade do século passado e no início deste século. O notável aumento na sobrevivência fica evidente pela retangularização destas curvas, com uma proporção muito maior de indivíduos que atingem as idades mais avançadas. Fica evidente pelo traçado que o componente que mais impactou nesta nova distribuição etária foi a queda na mortalidade infantil. Extraído de Arias (2006)

\subsubsection{Equação de Gompertz-Makeham}

Ainda em 1867, Makeham postulou que as curvas de mortalidade humana indicavam a existência de "pressões de mortalidade inerentemente irresistíveis", ou seja, cujas intensidades não dependiam da idade, ou seja, a mortalidade extrínseca. Para representar diretamente o efeito da ME, Makeham incluiu uma constante adi- 
tiva à Equação de Gompertz (Equação 2.1); a equação resultante (1860),

$$
m_{(t)}=A e^{G t}+E
$$

onde $E$ é a mortalidade extrínseca, é conhecida como a Equação de GompertzMakeham (Finch; Pike; Witten, 1990).

Embora a Equação 2.13, ao explicitamente separar o efeito da mortalidade extrínseca, tenha sido originalmente concebida como um refinamento da Equação de Gompertz (Equação 2.1), nenhuma delas é melhor a priori: situações ecológicas distintas podem levar à melhor aplicabilidade de uma ou de outra. Em geral, a Equação 2.13 tende a descrever melhor as curvas de mortalidade de populações sob as mais altas mortalidades extrínsecas, enquanto a Equação 2.1 é a melhor opção em populações sob baixas ME (Golubev, 2004; Gavrilov; Gavrilova, 2006).

\subsubsection{Desaceleração tardia da mortalidade}

Nas últimas décadas um novo componente na curva de mortalidade chamou a atenção de cientistas: a queda na aceleração da mortalidade, com consequente aumento do MRDT, identificado em populações humanas partir da oitava década de vida (Economos, 1985). O fenômeno não parece ser artefato ou oriundo simplesmente da mortalidade mais precoce das pessoas mais frágeis (Vaupel, 1997).

Notado inicialmente por Economos (1979), Economos e Lints (1985), este fenômeno tem sido descrito em em diversos animais invertebrados e alguns roedores (Economos, 1980, 1982), chegando a ocupar fração importante do ciclo de vida dos animais, como é o caso da mosca comum, Musca domestica, reproduzido na Figura 2.7.

Em idades muito extremas, esta desaceleração parece tender a platôs de 


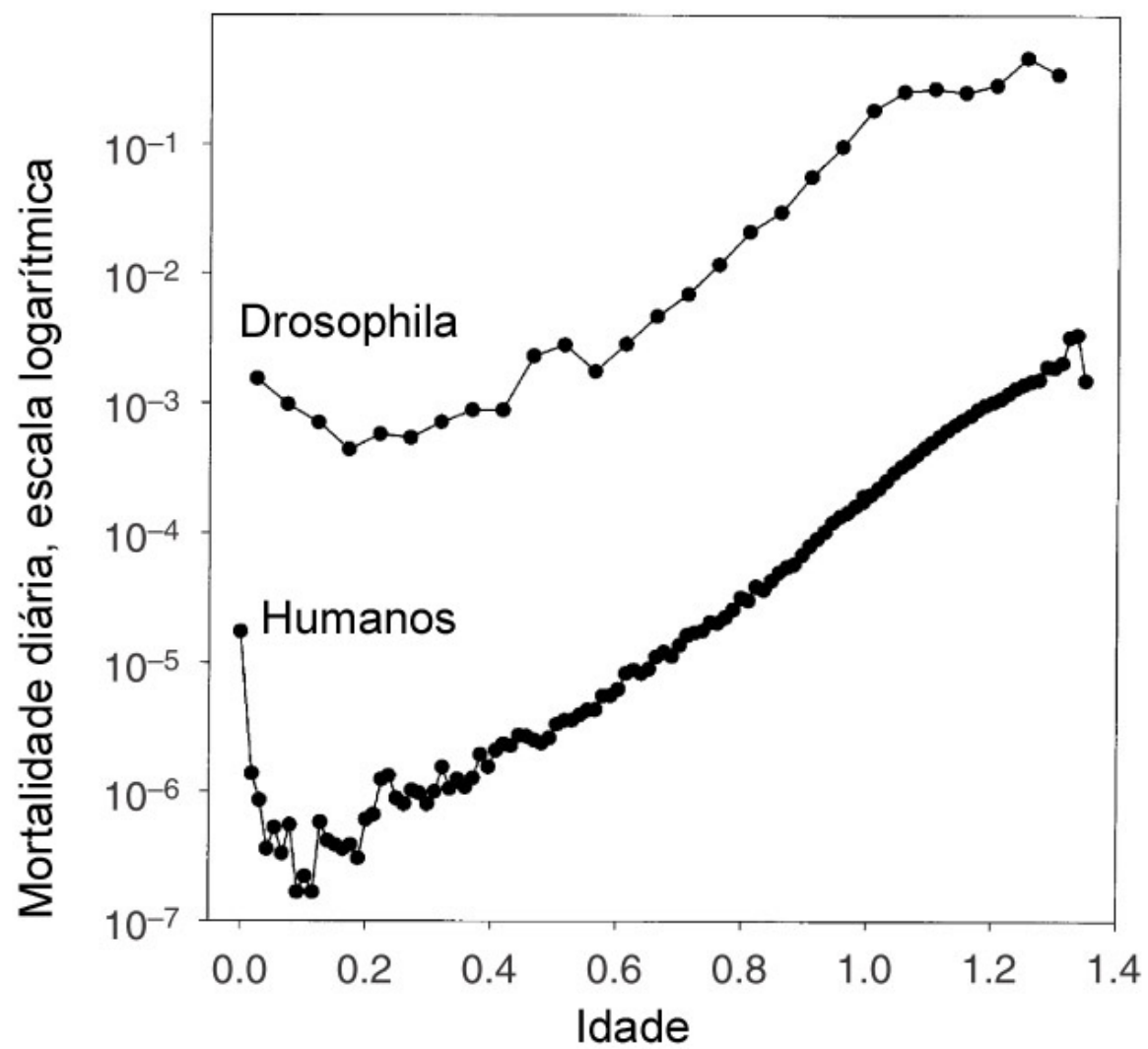

Figura 2.6 - Curva comparativa das trajetórias de mortalidade dehumanos e drosófilas. As taxas de mortalidade são calculadas em unidades idênticas (mortes por dia por indivíduo) em ambas as espécies. A escala de idade é normalizada por sua divisão pela longevidade, a fim de permitir a comparação das trajetórias de vida de ambas as espécies. Extraído de Gavrilov e Gavrilova (2006).

mortalidades máximas nos gráficos de mortalidade (Curtsinger et al., 1992; Vaupel, 1997). Este fenômeno tem levantado discussão sobre a real existência de um limite fixo para a expectativa de vida máxima da espécie humana, calculável em cerca de 120 anos através da função de sobrevivência de Gompertz (Finch; Pike, 1996). Este limite pode não existir de fato, ou, se existe, as observações atuais podem não estar próximas deste. Objeto de intensos debates, a desaceleração tardia das taxas de mortalidade ainda carece de uma explicação definitiva (Wilmoth, 1997). 


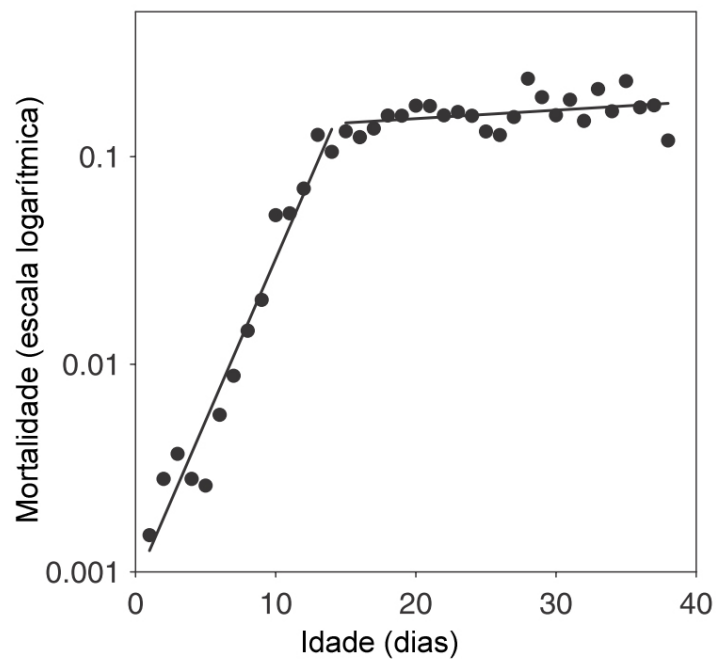

Figura 2.7 - Trajetória da mortalidade de uma população de 4.650 exemplares machos de moscas (Musca domestica), com crescimento Gompertziano inicial seguido de nivelamento tardio. As taxas de mortalidade foram calculadas através de tábua de mortalidade publicada por Rockstein e Lieberman (1959). Extraído de Gavrilov LA, Gavrilova NS. Reliability theory of aging and longevity. In: Masoro EJ, Austad SN (Ed.). Handbook of the Biology of Aging. 6th. ed. San Diego: Academic Press, 2006. 3-40.

\subsection{As Teorias da Senescência}

Se a primeira metade do século 20 não viu nenhuma hipótese sobre a evolução da senescência que tenha se sustentado (Kirkwood; Austad, 2000; Kirkwood, 2002), durante o mesmo período diversos autores buscaram caracterizar a senescência e explicar suas bases fisiológicas. Carrel (1912) acreditou ter demonstrado que células humanas mantidas em meio de cultivo se manteriam indiscrimicadamente sob divisão, ao contrário do que Weismann havia previsto. Loeb e Northrop (1917) foram os primeiros a notar o efeito da restrição calórica no aumento da longevidade de ratos. Minot (1908) observou correlação inversa entre o tamanho dos animais e sua longevidade. Acreditando estar interferindo unicamente no crescimento dos animais, Osborne, Mendel e Fey (1917) utilizou com sucesso a restrição calórica para prolongar a sobrevida de ratos. A partir do estudo de McCay, Crowell e May- 
nard (1935) sobre a restrição calórica, estava descoberto um novo mecanismo de interferência na longevidade, campo em estudo até os dias atuais.

A profusão de hipóteses produzida por esta corrente que olhou diretamente para o ser que senesce foi tamanha (ao final do século 20 mais de 300 teorias da senescência seriam elencadas (Medvedev, 1990)) que afirmava-se no meio acadêmico existirem tantas teorias de senescência quanto biogerontólogos no mundo (Hayflick, 1985). Esta hipérbole reforça a impressão de Comfort de que isto representaria uma falta de progresso no campo da senescência. Naquele que foi considerado por décadas o melhor livro da área (Austad, 1997b), Comfort critica (Comfort, 1956):

In almost any other important biological field than that of senescence, it is possible to present the main theories historically, and to show a steady progression from a large number of speculative, to one or two highly probable, main hypotheses. In the case of senescence this cannot profitably be done.

A maior parte destas múltiplas teorias, no entanto, é bem embasada em achados empíricos (Kirkwood; Austad, 2000). Por descreverem, em geral, mecanismos parciais e não excludentes pelos quais a senescência ocorreria nos indivíduos, não surpreende que tais teorias sejam numerosas (Gavrilov; Gavrilova, 2006). Com efeito, muitas das hipóteses formuladas ao longo do século 20 ainda são aceitas (Kirkwood, 2008). Esta aceitação, ao invés de constituir um prejuízo para o entendimento na área, levou ao reconhecimento de que a senescência é um fenômeno multifatorial (Masoro; Austad, 2006; Knight, 2000).

\subsubsection{Classificando as teorias da senescência}

Não há uma classificação consensual das teorias da senescência (Rose, 1991; Semsei, 2000). Embora o processo de senescência reconhecidamente envolva múltiplos mecanismos (Comfort, 1956; Masoro, 1985; Merry, 1987), ao ler as versões 
originais de muitas das teorias, como bem observa Austad, ficamos com a impressão de que cada uma tenha a primazia sobre o processo (Austad, 1997b).

Uma forma neutra e geralmente bem aceita de classificação é dividir as teorias da senescência entre aquelas que investigam as causas distais e as que enfocam as causas proximais da senescência (Rose, 1991; Austad, 1997b; Semsei, 2000; Gavrilov; Gavrilova, 2006). A seguir, podemos agrupá-las por semelhança.

As teorias que investigam as causas distais ou últimas da senescência buscam entender por que a senescência surgiu. Ao primeiro grupo pertencem a teoria do "bem da espécie" de Weismann (Seção 1.2.1), a teoria do uso e desgaste (wear and tear), a teoria da taxa de vida e as teorias evolutivas modernas. Destas, apenas as teorias evolutivas modernas ainda gozam de aceitação ampla (Finch; Pike; Witten, 1990; Austad, 1997b).

As teorias que investigam as causas proximais da senescência buscam entender por que os organismos senescem, ou seja identificar quais são os mecanismos de instalação da senescência no indivíduo Como tal, passaram a ser conhecidas na literatura especializada como teorias proximais ou mecanicistas da senescência. (Semsei, 2000).

\subsubsection{A teoria da taxa de vida}

Em 1908, Max Rubner descobriu uma relação entre a a longevidade, a massa corporal e a taxa metabólica em animais. Em resumo, as espécies animais mais longevas possuem, em média, maior massa corporal e gastam menos calorias por grama de massa corporal do que as espécies menos longevas. A partir desta observação, Rubner formulou a hipótese de que os animais nascem com uma capacidade fisiológica limitada e, quanto mais rápidos a utilizam, mais rápido vão morrer (Austad, 
1997b). Este raciocínio levou Perl a formular a hipótese de que, quanto mais rápida a taxa metabólica, mais rápido será o processo de senescência, criando a teoria da taxa de vida (Pearl, 1928).

Esta teoria, apoiada em evidências indiretas e uma série questionável de correlações inversas entre taxa metabólica e longevidade, foi bastante respeitada por mais de 50 anos, mas não é mais aceita atualmente no meio científico (Sinclair; Howitz, 2006).

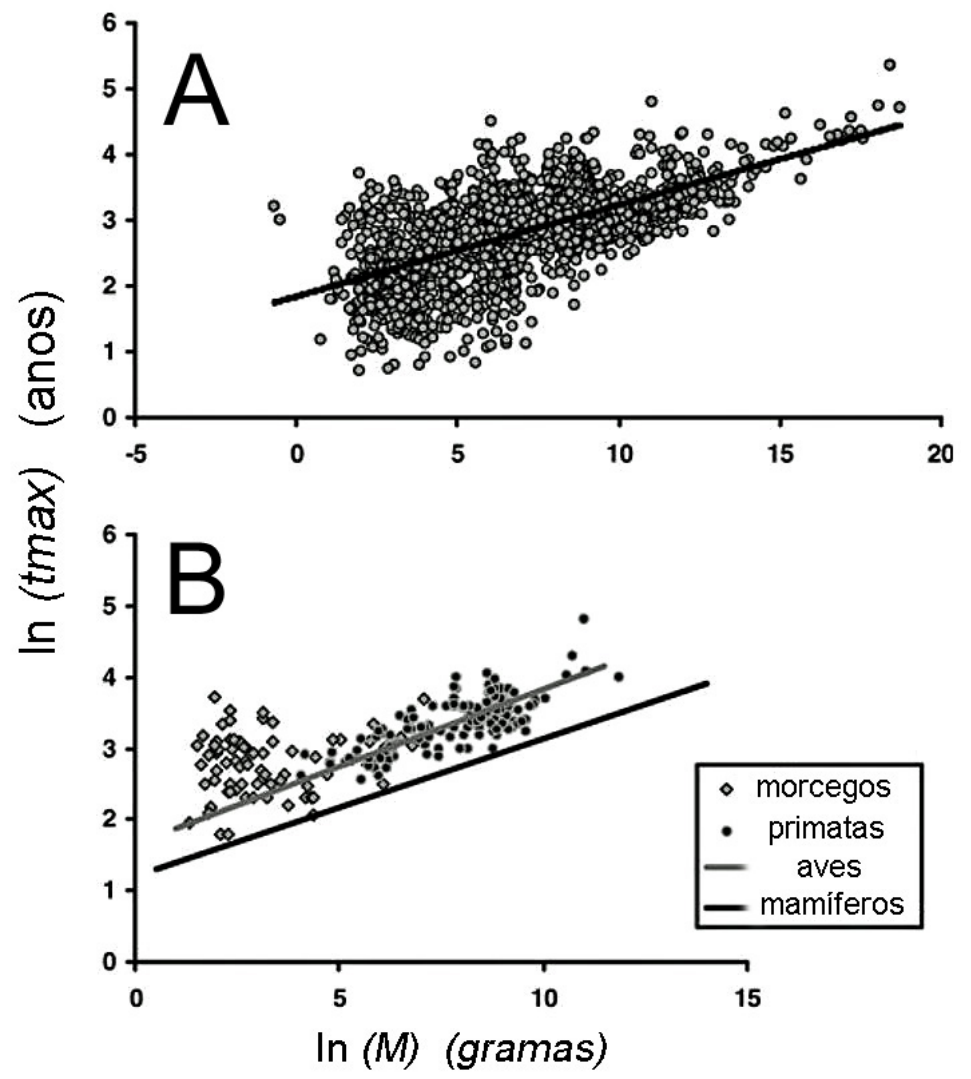

Figura 2.8 - Relação entre massa corpórea (M) e longevidade máxima (tmax) em vertebrados. A, círculos cinzas: todos as espécies de mamíferos, pássaros, répteis e anfíbios na base de dados AnAge $(\mathrm{n}=1456)$. B, Linha cinza: curva de regressão para as aves; linha preta: curva de regressão para mamíferos excluindo morcegos e cetáceos. Círculos negros: primatas $(\mathrm{n}=137)$ e quadrados cinzas: morcegos $(\mathrm{n}=73)$, as duas ordens de mamíferos mais longevas considerando-se a massa corpórea. Extraído de (de Magalhães; Costa; Church, 2007).

Um estudo já havia mostrado que marsupiais, que apresentam taxas me- 
tabólicas mais baixas que os mamíferos euterianos, vivem menos do que esperado por sua massa corpórea (Austad, 1997a). Mais recentemente, de Magalhães, Costa e Church (2007) recalculou, com dados modernos e para mais espécies, as relações entre taxas metabólicas, peso e longevidade de centenas de aves e mamíferos, concluindo que a taxa metabólica basal não está correlacionada com longevidade em mamíferos euterianos ou em aves; por outro lado, a magnitude da massa corpórea correlacionou-se diretamente com a longevidade (Figura 2.8) em 1456 espécies de répteis, anfíbios, aves e mamíferos.

A correlação entre massa corpórea e longevidade, ao invés de apoiar a teoria da taxa de vida, atualmente tem levado a uma busca por explicações ecológicas ou baseadas nas modernas teorias evolutivas da senescência.

Por exemplo, animais de menor massa corporal tendem a sofrer mais predação do que animais maiores; estes, além disto, em geral ocupam nichos ecológicos em que podem obter alimento suficiente para manutenção de tais massas. Em conjunto, isto quer dizer que a mortalidade extrínseca tende a ser inversamente proporcional à massa de cada espécie (Austad, 1997b). Se maiores mortalidades extrínsecas exercem de fato pressão evolutiva no sentido da senescência (tanto quanto fazem sobre estratégias $\mathrm{r}$ e K), então isto explicaria por que animais menores vivem menos.

Neste sentido é muito importante analisar o que acontece com as exceções. Morcegos, cuja , embora pequenos, são os únicos mamíferos que voam. Ao contrário dos ratos (muito mais aparentados geneticamente a estes do que aves), os morcegos não são sujeitos às altíssimas predações como são os ratos e alcançam fontes de alimento também inacessíveis aos ratos. Ocupam um nicho ecológico e uma estratégia de vida semelhante à das aves e, interessantemente, apresentam 
longevidade muito maior do que a de roedores de mesmo porte, mas comparável a de aves de mesmo porte (de Magalhães; Costa; Church, 2007).

Apesar da relação entre taxa metabólica e longevidade que Rubner e Pearl documentaram, esta possui muitas exceções. Por exemplo, embora tendam a possuir taxas metabólicas maiores do que mamíferos (podendo chegar ao dobro), as aves vivem pelo menos três vezes mais do que mamíferos de mesmo tamanho (ignorandose os morcegos) (Austad, 1997b). Morcegos e ratos, por sua vez, em média possuem tamanho e taxas metabólicas semelhantes, mas um morcego em geral vive cerca de 5 vezes mais do que um rato (Wilkinson; South, 2002). Casos específicos são ainda mais notáveis: o rato-toupeira-pelado (Heterocephalus glaber), um roedor do tamanho de um camundongo, possui longevidade de cerca de 30 anos (Edrey et al., 2011). O Morcego de Brandt adulto (Myotis brandtii) pesa em média 7 gramas e tem uma expectativa de vida máxima documentada em 41 anos (Munshi-south; Wilkinson, 2010). O rato-toupeira-pelado tem um porte semelhante a qualquer rato, mas diferentemente dos ratos, vive em um ambiente quase livre de predadores; sua longevidade é de cerca de 28 anos (Edrey et al., 2011).

Por possuírem aspectos ecológicos muito peculiares, tais espécies podem ter apresentado uma história evolutiva distinta em relação à senescência (Austad, 1997b; Rose, 1991). 


\subsubsection{As teorias mecanicistas da senescência}

\subsubsection{Teorias estocásticas}

A base deste grupo de teorias é o acúmulo intracelular de macromoléculas danificadas ao acaso. Tais macromoléculas poderiam acumular-se por erros aleatórios na síntese proteica ou por falha em reparar danos. A progressiva perda de função celular resultante deste processo estaria ligada à senescência (Medvedev, 1990).

Teorias do uso e desgaste Fundamentam-se na ideia de que múltiplos acidentes de ordem mecânica se acumulariam nos organismos com incapacidade de reparo, culminando com o aumento exponencial da fragilidade causada por tais acidentes. Tais teorias encontram-se atualmente em descrédito. Argumentar que senescemos porque cada uma de nossas pequenas partes envelhece utiliza mecanismos de senescência para explicar a origem da senescência e pouco nos ilustra em relação às causas deste processo (Gavrilov; Gavrilova, 2006). Argumentar, por outro lado, que elefantes geralmente morrem de fome após perder sua sexta dentição por uso e desgaste, por mais que seja real, não ajuda o progressivo aumento na mortalidade que caracteriza o processo de senescência (Jeckel-neto; da Cunha, 2002).

Mutações somáticas Esta teoria fundamenta-se na ideia de que o acúmulo de mutações no DNA de células somáticas ao longo da vida prejudicaria a capacidade destas células de desempenharem suas funções metabólicas, até níveis letais. Há, no entanto, pouco suporte de que este mecanismo poderia ter grande impacto na senescência. 
Teoria do erro catastrófico A ideia central desta teoria é que a capacidade da célula para produzir proteínas funcionais depende não somente da informação genética, mas da integridade do aparato de síntese proteica. Mesmo na ausência de mutações somáticas, poderia haver erros na síntese proteica (Orgel, 1963). Estes erros poderiam ser transmissíveis e cumulativos caso as proteínas incorretamente traduzidas estivessem envolvidas na síntese proteica, levando a um acúmulo exponencial de erros. Quando a ocorrência de erros atingisse um nível crítico, ocorreria um erro catastrófico, no qual os processos celulares se tornariam letalmente disfuncionais.

Danos a proteínas de baixo turnover Proteínas de baixo turnover incluem diversas enzimas fundamentais para a função celular. Danos através de crosslinks de proteínas por colágeno (Verzar, 1969), espécies reativas de oxigênio (Harman, 1981) ou glicosilação não enzimática (Cerami, 1985) alterariam a atividade enzimática, comprometendo a eficiência do metabolismo celular. A senescência seria consequência dos prejuízos funcionais causados por disfunção e morte celular.

\section{Espécies reativas de oxigênio e radicais livres $O$ cerne desta teoria, pro-} posta por Harman (1956), é que a senescência seria o resultado do acúmulo de danos celulares causados por espécies reativas de oxigênio (EROs), subprodutos do metabolismo do oxigênio. Estes danos poderiam ser a proteínas, como mencionado, mas também incluiriam a peroxidação lipídica e danos ao DNA somático(Harman, 1998). As diferentes velocidades da senescência em distintas espécies refletiria o grau de dano por EROs e a competência das defesas anti-oxidantes de cada espécie (Harman, 1981, 2006).

Uma evidência em favor desta teoria é que existem enzimas, como a cata- 
lase, a glutationa-peroxidase e a superóxido-dismutase, especificamente capazes de transformar certas EROs em substâncias menos tóxicas. Tais enzimas são universalmente encontradas em animais aeróbicos (Harman, 2006). No entanto, embora evidências experimentais de que as EROs influenciam na senescência de invertebrados são numerosas, não há evidencias claras de que influenciem na senescência de mamíferos (de Magalhães, 2005).

\subsubsection{Os telômeros e a senescência celular}

Ao estudar a divisão de fibroblastos humanos em cultura, Hayflick descobriu que estas células não se dividem por período indefinido como acreditado até então . Ao contrário, após um período de divisão normal, estas células entram em um período de declínio, parando de se dividir (Hayflick; Moorhead, 1961). Este fenômeno foi chamado de senescência replicativa e Hayflick associou-o como um possível mecanismo da senescência (Hayflick, 1965). Sabe-se hoje do envolvimento dos telômeros neste processo (Hayflick, 1998).

\subsubsection{Senescência demográfica e a fiabilidade das máquinas}

Embora animais multicelulares sejam muito diferentes das máquinas que construímos por serem auto-construídos a partir de uma célula e serem capazes de auto-reparo (Austad, 1997b), traçar um paralelo entre a senescência biológica e o envelhecimento das máquinas não deixa de ser interessante. Tampouco é óbvio: tal paralelo, como veremos, não é a simples comparação com o carro que inevitavelmente fica velho porque suas partes se desgastam, mas o de como isto acontece com as máquinas complexas. Certamente, máquinas cujas taxas de ocorrência de falhas não aumentassem com o tempo de uso poderiam, por analogia ao processo biológico, ser consideradas máquinas que não senescem. De fato, como pontua Comfort (1956), 
há máquinas cujo risco de quebra não muda com o tempo de uso.

Kurtz e Winfrey (1938), no entanto, notaram que as curvas de falhas de distintas máquinas, como radares e telefones, guardavam semelhança com as curvas da mortalidade humana: as probabilidades de quebra de tais máquinas aumentavam com o tempo de uso.

A engenharia descreve tais quebras como falhas, termo que acomoda melhor o que se precisa descrever: a incapacidade de desempenhar de acordo com o previsto para a situação de uso planejada. O campo de estudo que descreve como as máquinas complexas falham chama-se teoria da fiabilidade, ou reliability theory. O nome se dá porque as máquinas complexas tendem a apresentar falhas a taxas crescentes com seu tempo de uso, tornando-se progressivamente menos confiáveis (Gavrilov; Gavrilova, 2001) .

Uma maneira bastante eficiente de aumentar a fiabilidade de uma máquina (ou seja, de diminuir a probabilidade de falhas) é aumentar a redundância do projeto, através da paralelização de componentes em funções essenciais originalmente desempenhadas por componentes únicos (Figura 2.9). Em uma máquina sem redundância, se um componente essencial falha, a máquina como um todo falha. Se mais componentes, com arranjo em paralelo, realizam a mesma função, a falha de um deles não impede completamente o funcionamento da máquina. Quanto mais componentes em paralelo, maior a redundância de um projeto e maior a fiabilidade da máquina (Gavrilov; Gavrilova, 2001).

Uma máquina equivalente cuja função é desempenhada por um componente único (i.e., não possui redundância) apresentará taxas de falha total no seu período inicial de seu uso muito maiores do que a máquina cuja função é redundante. Isto porque, com arranjo redundante, para cada redundante que vier a falhar, a máquina 
desempenhará um pouco pior, mas não apresentará falha total enquanto um número de componentes necessário para seu funcionamento mínimo estiverem operacionais. Como a Figura 2.10 ilustra, isto permite o acúmulo de danos no sistema, que tolerará uma perda parcial e progressiva de função, até a falha com a perda total de funcionamento da máquina (Gavrilov; Gavrilova, 2006).
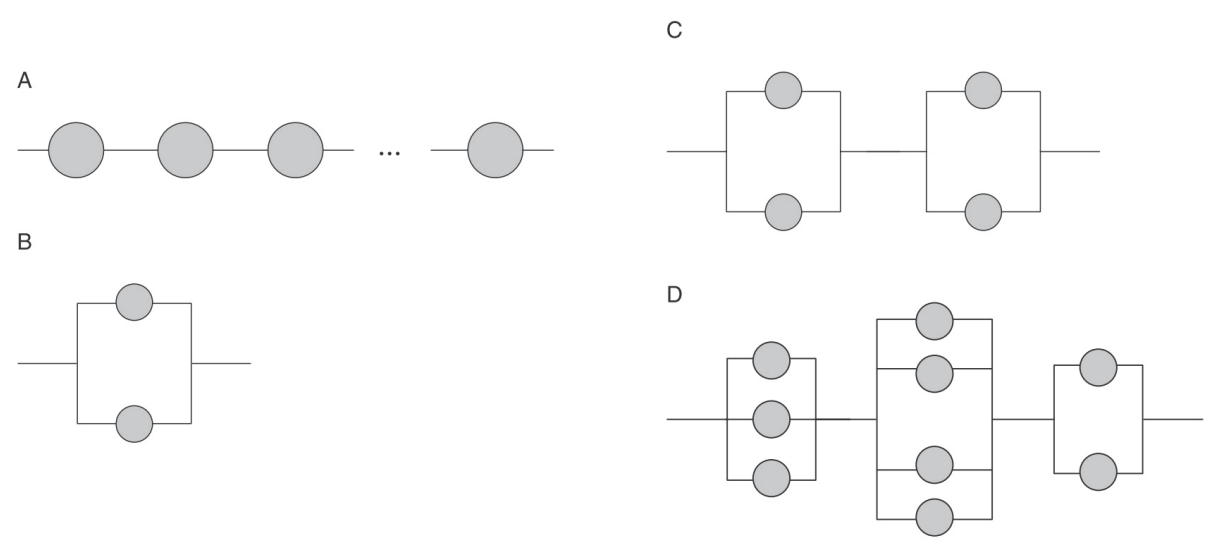

Figura 2.9 - Redundância e reserva funcional. Representação esquemática de distintos arranjos lógicos. A. Um sistema em série. B. Um sistema em paralelo. $C$. Um sistema em série-paralelo com igual redundância de seus componentes. D. Um sistema em série-paralelo com redundância distribuída (variável) de seus componentes. Extraído de Gavrilov LA, Gavrilova NS. Reliability theory of aging and longevity. In: Masoro EJ, Austad SN (Ed.). Handbook of the Biology of Aging.

Para as máquinas complexas, a regra mais aceita para descrever a incidência de falhas é a lei de Weibull. Nesta, o aumento da taxa de falhas ao longo do tempo de uso obedece a uma lei de potências:

$$
\mu(x)=a x^{b}
$$

onde $\mu(x)$ é a taxa de ocorrência de falhas na idade $x, x \geq 0$ e $a, b>0$.

É interessante comparar a Equação de Weibull (Equação 2.14) com a equação de Gompertz (Equação 2.1), escrita abaixo com os mesmos termos usados na 
A

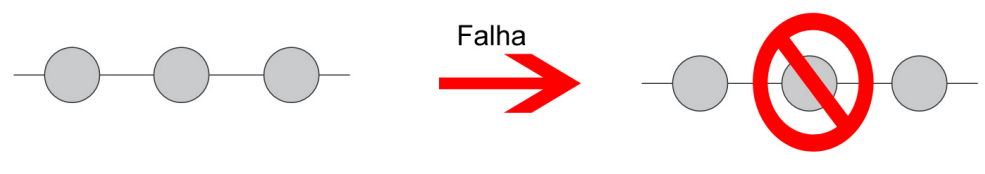

8

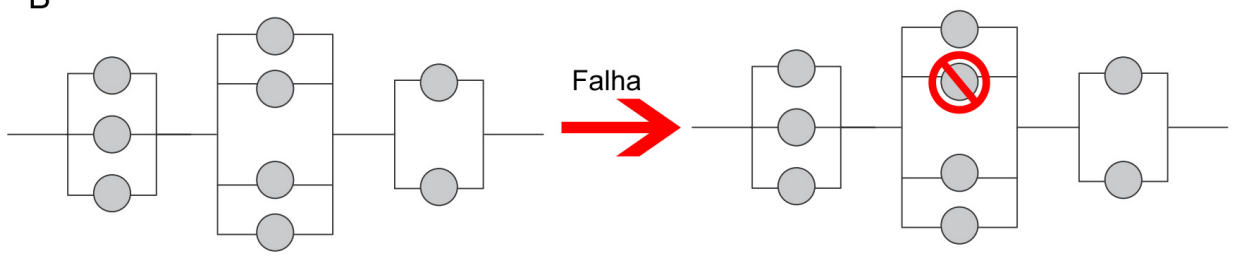

Figura 2.10 - Redundância e senescência. A. Sistemas sem redundância de componentes não exibem falhas parciais: a perda de um único componente resulta em falha total (morte). B. Sistemas com componentes redundantes (esquema inferior) podem tolerar falhas parciais de seus componentes redundantes sem que isto resulte em falha total (morte). No entanto, ao permitirem falhas em componentes redundantes, também permitem perda de reserva funcional (senescência). Modificado de de Gavrilov LA, Gavrilova NS. Reliability theory of aging and longevity. In: Masoro EJ, Austad SN (Ed.). Handbook of the Biology of Aging. 6th. ed. San Diego: Academic Press, 2006. 3-40.

Equação 2.14:

$$
\mu(x)=A e^{G x} .
$$

Na equação de Gompertz, o logaritmo das taxas de falha ou morte aumenta linearmente com a idade, enquanto que na equação de Weibull, o logaritmo das taxas de mortalidade ou falha aumenta linearmente com o logaritmo da idade. Assim, enquanto uma série que obedece a lei de Gompertz pode ser imediatamente identificada como uma reta no gráfico "semi-log", uma série que obedeça a lei de Weibull constitui uma reta em um gráfico "log-log".

Outra diferença relevante é dada na idade 0: nesta idade, de acordo com a lei de Weibull (Equação 2.14), os sistemas apresentam taxa de falha igual a zero, ao passo que, pela lei de Gompertz (Equação 2.15), na idade 0 a mortalidade é descrita por $A$, ou seja, organismos vivos apresentam uma "probabilidade de falha" inicial 
não-desprezível. Isto faz sentido: enquanto máquinas em geral podem ser projetadas para, sendo novas, terem taxas de falha iguais ou próximas de zero, em animais, a mortalidade de neonatos não é de maneira nenhuma desprezível (em verdade, em muitos casos, supera a mortalidade de indivíduos jovens já desenvolvidos, como ilustra a Figura 2.2.

As semelhanças entre os padrões de mortalidade de seres vivos e das taxas de falha de máquinas complexas levou Gavrilov a propor, a partir dos anos 1980, a Teoria de Fiabilidade do Envelhecimento (Reliability theory of aging. Nas palavras de Gavrilov, "por que máquinas 'preferem' falhar segundo a Lei de Weibull e os organismos vivos 'preferem' morrer de acordo com a Lei de Gompertz" parecia um grande mistério. Isto o levou a propor a hipótese da alta carga inicial de danos. A partir da hipótese de que organismos biológicos possuem muitos componentes organizados em paralelo (néfrons, fibras musculares, vias neurais, etc.), de modo que a perda de um componente possa lentificar mas não destruir o sistema, ele postulou que, em espécies com senescência típica como a nossa, os indivíduos já nascem com danos instalados em diversos componentes do organismo. Pela lógica que aplica a lei de Weibull para máquinas, a idade dos seres vivos ao nascer é superior a zero, pois o nascimento não é o início de sua "fabricação" (Gavrilov; Gavrilova, 2001).

De fato, ao utilizar a equação de Weibull para descrever as taxas de falha de um sistema fictício com uma grande redundância de componentes e grande quantidade de danos já estabelecidos e considerando-se a idade ao nascer maior que zero, Gavrilov obteve curvas de mortalidade bastante semelhantes às obtidas pela equação de Gompertz, bem como por dados reais (Gavrilov; Gavrilova, 2006).

Em suma, a imagem que poderíamos fazer da senescência de um ser vivo não é a imagem singela de um objeto que envelhece por simples ação do tempo, mas 
de uma máquina construída com diversos sistemas em paralelo e tão complexa que, funcionando durante seu período de fabricação, já possui defeitos no início de seu uso. Para complicar, além de reservas, já mencionamos que esta máquina complexa possui diversos sistemas de auto-reparo, mas apesar de ambos, senesce e morre.

\subsubsection{Restrição calórica e senescência}

Em 1935, McCay e colegas descobriram que poderiam aumentar a longevidade em ratos de laboratório apenas fazendo-os comer menos calorias, mantendo níveis normais de proteínas, vitaminas e minerais (Mccay; Crowell; Maynard, 1935). Esse processo ficou conhecido como a restrição calórica $(\mathrm{RC})$ e parece funcionar em distintos animais. Seus resultados têm sido validados em dezenas de laboratórios e em espécies distintas, dentre estas, leveduras, peixes, roedores e cães (Sinclair; Howitz, 2006).

(Weindruch; Walford, 1982) Adult Mice On Dietary Restriction Live 20\% Longer And Have Lower Cancer Rates olvimento Investiga-se atualmente qual seria o nível ótimo de restrição (Sinclair; Howitz, 2006).

Weindruch realizou severas restrições de até $65 \%$ (i.e., os ratos comiam $35 \%$ das calorias comeriam livremente) - e o grupo de maior restrição foi o mais longevo (Weindruch, 1996)

Embora os resultados seja sólidos, uma dúvida que se colocou foi saber se os camundongos e ratos de laboratório alimentados ad libitum são representativos da situação natural: talvez os indivíduos em RC tenham uma dieta mais próxima daquela praticada no ambiente natural (Austad, 2001). Resultados posteriores sugerem que este não é o caso: após correção para a massa corporal, mostrou-se que os camundongos de laboratório alimentados ad libitum não comem mais do que os 
camundongos selvagens (Austad; Kristan, 2003).

Diversas teorias foram propostas para explicar os efeitos da RC nos mamíferos (Sinclair; Howitz, 2006). Dentre estas, a de que a restrição calórica exerce efeitos horméticos sobre longevidade e a senescência, ou seja, existiria um grau ótimo de restrição calórica, fora do qual a senescência se instalaria mais rapidamente (Masoro; Austad, 2006). Uma hipótese mais ampla seria de que o efeito hormético da RC seria causado pela indução de um programa genético único e evolutivamente conservado, que ativasse mecanismos de reparo e defesa que contrabalançariam as causas proximais da senescência(Weindruch et al., 2001).

Atualmente, a RC é a única intervenção que consegue adiar a a velocidade da senescência em mamíferos (através do aumento do MRDT), constituindo um dos campos mais promissores da biogerontologia. eventual adaptação para sobreviver a situações de carência (Sinclair; Howitz, 2006).

\subsection{As origens evolutivas da senescência}

Com a lacuna criada pelo abandono por Weismann de sua hipótese sobre a evolução da senescência, uma explicação óbvia seria não haver origem evolutiva para a senescência: esta representaria unicamente o resultado final dos mecanismos em investigação ao longo da primeira metade do século XX. Reforçando a hipótese não evolutiva, começavam surgir evidências de que a senescência era amplamente distribuída através de diversos grupos filogenéticos. Teorias como aquelas descritas na Seção 2.3.3 davam a entender que a senescência fosse uma inerência ou da montagem dos animais multicelulares ou da impossibilidade biológica para determinados grupos de animais em lidar com danos causados pelo seu desenvolvimento, e pela sua fisiologia. Em suma, para uma determinada classe de animais, a senescência 
seria simplesmente uma característica biológica (Comfort, 1956).

Ocorre que há espécies com senescência desprezível (Finch; Pike; Witten, 1990). Esta pode ser definida em termos do intervalo de duplicação da mortalidade (o MRDT) ou da fertilidade. A título de exemplo, o Sebastes aleutianus, uma espécie de peixe-pedra com longevidade de até 205 anos (Cailliet et al., 2001), parece manter oogênese até o final da vida (de Bruin et al., 2004). A tartaruga de Blanding (Emydoidea blandingii) pode passar dos 75 anos e mostra aumento de fertilidade e redução de mortalidade com o passar dos anos (Congdon et al., 2001).

Outro indício de que a senescência está sujeita a variações é esta ser muito mais proeminente em certos grupos biológicos, como é o caso entre répteis e mamíferos: enquanto répteis aparentam senescência muito mais lenta (maiores $M R D T$ ) e algumas espécies até mesmo mostram pouco ou nenhum sinal de senescência, todos os mamíferos exibem tais efeitos (de Magalhães; Toussaint, 2002). Este argumento, portanto, não faz sentido.

À medida em que mais informação era disponível, ficava claro que animais de espécies distintas apresentavam longevidades muito distintas

Não parecia possível explicar por que a senescência existe apenas considerandoa um apanágio da vida. Diante disto, fazia sentido perguntar:

- existe algum impedimento para que a seleção natural atue na remoção de características deletérias ligadas à senescência $e$ / ou na manutenção da integridade do organismo por tempo indefinidamente longo?

— se não existe impedimento, então existem situações evolutivas relativamente comuns em que a manutenção do organismo não é o cenário ótimo? 


\subsubsection{A força da Seleção Natural cai com a idade}

Suponhamos que uma determinada mutação genética exerça um efeito apenas a partir de uma certa idade. Se esta idade anteceder a maturação sexual, os efeitos desta mutação sobre a aptidão de seu portador influenciarão toda sua prole futura. Se uma mutação for mais tardia, terá menos efeitos sobre a aptidão, uma vez que seu portador poderá já ter se reproduzido ou morrido por outras causas. Esta ideia foi formalizada em 1930 por Fisher, através do conceito de valor reprodutivo (v) (Fisher, 1930). O valor reprodutivo em uma certa idade $i\left(v_{i}\right)$, é dado por:

$$
\text { (a) } v_{i}=\frac{\sum_{y=i}^{\infty} \ell_{y} m_{y}}{R} \text { ou (b) } v_{i}=\frac{\int_{y=i}^{\infty} \ell_{y} m_{y} d y}{R},
$$

onde $R$ é a fertilidade líquida da população (já descontadas as perdas de reprodução por mortalidade ao longo da distribuição etária):

$$
\text { (a) } R=\sum_{y=0}^{\infty} \ell_{y} m_{y} \text { ou } \quad \text { (b) } R=\int_{0}^{\infty} \ell_{i} m_{i} d i
$$

onde $\ell_{i}, m_{i}$ e $y$ são, respectivamente, a probabilidade de sobrevivência até a idade $i$ a fertilidade média na idade $i$ e $y$ é a variável ligada utilizada para correr a somatória ou a integral nos intervalos indicados pelas equações. Utilizamos as Equações 2.16(a) e 2.17(a) ou as Equações 2.16(b) e 2.17(b) dependendo de a população se reproduzir em gerações discretas (a) ou em gerações contínuas (b). Fica claro que $v_{i}$ é função de $\ell_{i}, m_{i}$.

Se supomos a senescência como uma propriedade inerente à vida, então podemos imaginar que $\ell_{i}$ e $m_{x}$ necessariamente cairão com o incremento etário. Desta forma, um determinado coeficiente seletivo $S$ para um gene com efeito idadedependente oscilará em função desta idade, caindo com o avançar da idade.

Como, Fisher observou, "as taxas de mortalidade em humanos têm um curso 
geralmente inverso ao da curva do valor reprodutivo" (Fisher, 1930), ou seja, nas idades em que este é máximo, a mortalidade tende a ser mínima.

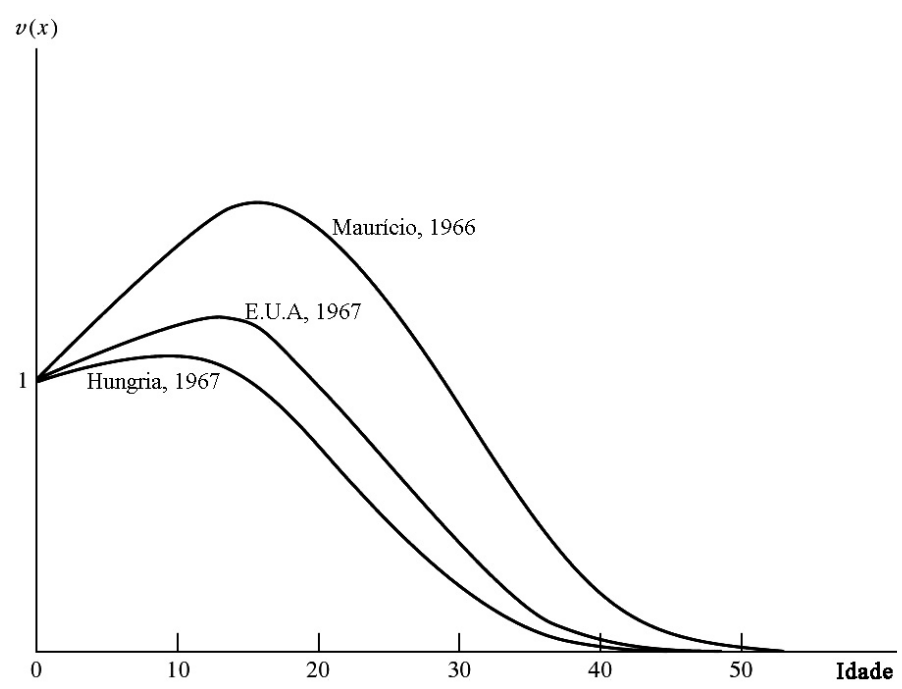

(a) Valor reprodutivo $(v)$ em relação à idade.

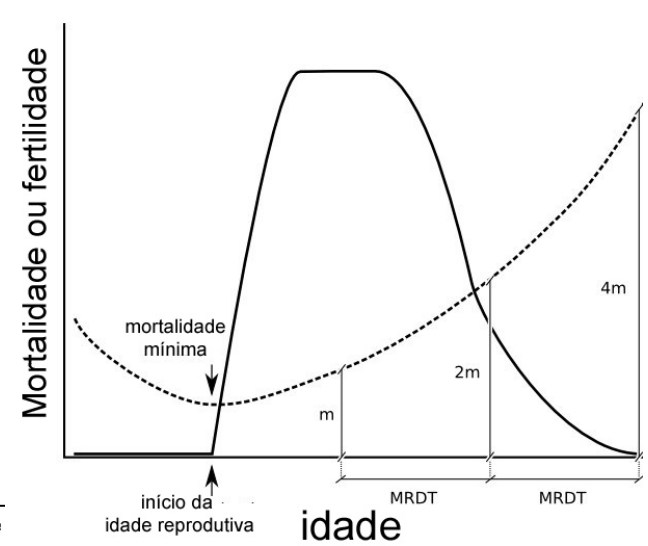

(b)

Figura 2.11 - 2.11a: Valor reprodutivo $(v)$ em relação à idade para mulheres em 3 diferentes países. Extraído de Keyfitz (2005). 2.11b: Representação didática da senescência em mulheres. A partir de um valor mínimo por volta dos 12 anos de idade, a mortalidade cresce exponencialmente (linha pontilhada). A partir de um rápido início por volta dos 12 anos, a fertilidade cai lentamente, sofrendo uma queda abrupta (menopausa). A Figura 2.11a mostra que as idades de mínima mortalidade coincidem com o máximo valor reprodutivo.

Caberia a Bidder, em 1931, a primazia de notar que a queda na força da seleção natural sobre características expressas em idades avançadas poderia ter importância na evolução da senescência. Bidder argumenta que a senescência após os 36 anos de idade em humanos primitivos, (estimando início da idade reprodutiva aos 18 anos) não teria impacto para a espécie, uma vez que tais indivíduos "já teriam filhos capazes de cuidar de seus netos" (Bidder, 1932). No entanto, Bidder não leva em conta que, todo o resto mantendo-se igual, um indivíduo mutante capaz de se reproduzir até os 100 anos teria sua aptidão muito mais elevada do que seu pares.

Embora não tenha proposto uma teoria com um mecanismo operacional, já 
em 1932, Bidder propõe a hipótese de que a senescência seria (Bidder, 1932)

...não a manifestação de uma fraqueza inerente ao protoplasma ou característica das células nucleadas, mas o subproduto sem importância de um mecanismo regulatório necessário para a sobrevivência de qualquer raça (...), um mecanismo evoluído através de seleção e sobrevivência.

Em terminologia mais contemporânea, Bidder afirma, a um só tempo, que a senescência

1. não é necessariamente um fenômeno intrínseco à Vida;

2. pode ser subproduto de mecanismos fisiológicos;

3. pode ter evoluído por não exercer impacto suficientemente deletério (i. e. não tem importância);

4. pode ter evoluído em conjunto com um mecanismo fisiológico.

Como veremos, algumas destas ideias são ecoadas nas teorias evolutivas atualmente aceitas sobre a senescência.

\subsubsection{Haldane e a doença de Huntington}

Em 1941, Haldane publica para o público leigo um livro intitulado New paths in genetics. Neste, Haldane discorre sobre como a Doença de Huntington, uma doença genética grave, poderia ter escapado àq eliminação por seleção natural. A partir desta análise, Haldane teria um estalo de Vieira relacionado à a evolução da senescência.

A Doença de Huntington é uma doença genética grave, autossômica dominante, bastando um único gene para fadar seu portador a desenvolvê-la, contanto que viva o suficiente. Isto porque os primeiros sintomas em geral começam após os 30 anos de idade. De forma progressiva, funções neurológicas são progressivamente 
danificadas, desencadeando dificuldades para as tarefas mais simples. Finalmente, o sistema nervoso autônomo não é capaz de exercer suas funções e a morte é certa (Haldane, 1941).

O que chamou a atenção de Haldane é esta doença ter mantido sua transmissão na espécie humana em vez de ser eliminada pela seleção natural. Haldane concluiu que a seleção natural não pôde eliminar a doença devido à da idade tardia em que a manifestação dos seus sintomas se iniciava. Como já se acreditava, a seleção natural teria muito pouca força em idades avançadas.

Haldane argumentou que, antes da civilização, poucas pessoas sobreviveriam até os 40 anos e as que sobrevivessem provavelmente já teriam se reproduzido, de modo que o gene para a Doença de Huntington, na verdade, era seletivamente neutro, podendo ter-se fixado por deriva genética (Rose et al., 2008).

\subsection{A Teoria do Acúmulo de Mutações de Me- dawar}

Embora Haldane tenha relacionado a queda da força da seleção natural com a fixação de uma característica genética nitidamente deletéria como a Doença de Huntington (Haldane, 1941), ele não chegou a transformar esta observação em uma teoria da senescência. Coube a Medawar fazê-lo (Medawar, 1952).

Medawar notou que não havia necessidade da existência do processo de senescência para que as populações selvagens tivessem, necessariamente, uma estrutura etária. Para isto, bastava a existência de uma probabilidade constante de morte, determinada pelos riscos ambientais, como fome, predação, acidentes, etc. Esta é a mortalidade extrínseca. 
Sujeitas à mortalidade extrínseca, populações selvagens seriam compostas predominantemente de indivíduos mais novos, com raros indivíduos nas idades mais avançadas da distribuição. Este é, aliás, o terceiro erro na formulação da teoria de Weismann (Seção 1.2.1): idosos em populações naturais são necessariamente mais raros; portanto, não consomem parte expressiva dos recursos ambientais.

Ao contrário de ser mais um empecilho a uma teoria evolutiva da senescência, Medawar fez disto a base de sua teoria. Mesmo em uma população não senescente, desde que exposta a uma mortalidade extrínseca constante, a distribuição etária se assemelharia àquela da Figura 2.13. Embora neste modelo a fertilidade $\left(m_{i}\right)$ se mantenha constante com a idade, a probabilidade de sobrevivência até uma idade avançada, $\ell_{i}$, cai dramaticamente. Assim, a capacidade de uma mutação deletéria em afetar o valor reprodutivo cai com o aumento da idade.

Mutações deletérias, desde que em idades suficientemente avançadas, poderiam acumular-se nos genomas (Medawar, 1952). De acordo com os mecanismos da genética de populações, a senescência não é necessariamente prejudicial: a proposição original de Medawar implica que o adiamento dos efeitos idade-específicos de genes deletérios para idades suficientemente tardias é equivalente à sua eliminação. Deste modo, estes genes se tornam efetivamente neutros. Assim, o resultante adiamento de efeitos deletérios é benéfico e a senescência poderia ser considerada como um efeito colateral deste processo.

De acordo com a teoria de Medawar, este mecanismo evolutivo poderia explicar apenas as manifestações senescentes encontradas em populações protegidas, depois que indivíduos atingissem idades acima daquelas encontradas na natureza. Medawar, no entanto, aceitava que os efeitos da senescência também ocorriam em idades comumente encontradas na natureza. Por esta razão, convenceu-se de que 
outra hipótese, envolvendo pleiotropia ou linkage, seria necessária para explicar o processo precoce e gradual de degeneração orgânica que constitui a senescência ao invés apenas de manifestações tardias. Medawar, no entanto, não deu mais detalhes sobre esta hipótese.

\subsection{A Teoria da Pleiotropia Antagônica de Willi- ams}

Embora o acúmulo de mutações justifique a existência de genes deletérios com expressão tardia, a teoria do acúmulo de mutações não parece explicar o lento processo e precoce de senescência, mas o estado senescente já estabelecido (Williams, 1957).

Caso a senescência fosse um processo abrupto com início muito próximo ao estado senescente, poderíamos entender ambos como quase sinônimos: em algum momento no fim do ciclo vital o fenótipo senescente se instalaria abruptamente, com imediato aumento da taxa de mortalidade e queda da fertilidade. Não é o que se observa. A senescência é caracterizada por uma alteração precoce na mortalidade e na fertilidade, e progride gradualmente até idades avançadas. Isto significa que ao menos parte de sua programação genética se expressa em idades precoces, em que a força da seleção natural é alta.

Buscando entender como efeitos genéticos deletérios expressos em idades relativamente precoces poderiam escapar à seleção, Williams fundamentou sua teoria em quatro premissas: a existência de uma linhagem celular somática, ou seja, não transmissível em todo ou parte através da reprodução sexuada ou assexuada; a seleção natural de diferentes alelos em uma população; decrescente probabilidade de reprodução com o aumento da idade adulta; a existência de genes pleiotrópicos 
com diferentes efeitos na viabilidade em diferentes idades — ou seja, com diferentes efeitos em diferentes momentos (pleiotropia antagônica). De acordo com esta idéia, o processo evolutivo fundamental para o surgimento e manutenção do envelhecimento é a ação seletiva sobre a herança de um gene com efeitos antagônicos sobre a aptidão de seus portadores (Williams, 1957).

A existência de genes pleiotrópicos com efeitos antagônicos não foi postulada por Williams. Em artigo prévio, Sewall Wright descreve uma equação para o cálculo do impacto de um gene pleiotrópico na aptidão de seu portador:

$$
W=\left(1+S_{1}\right)\left(1+S_{2}\right) \ldots\left(1+S_{n}\right)
$$

onde $W$ é a aptidão de um gene e $S_{1}, S_{2} \ldots S_{n}$ são os coeficientes seletivos medidos separadamente para cada efeito de um gene pleiotrópico sobre a aptidão (Wright, 1956).

O mérito de Williams foi notar a implicação da equação de Wright para a evolução da senescência em populações estruturadas. à Equação 2.18, Williams aplicou o mesmo raciocínio aplicado por Medawar em relação à estruturação etária das populações: se a magnitude do efeito $S_{n}$ de um gene poderá ser reduzida caso se inicie em idades avançadas, em um gene pleiotrópico capaz de manifestar diferentes efeitos em idades distintas, efeitos mais tardios estarão sujeitos a menor seleção do que efeitos mais precoces. Até este ponto, nada de novo: é exatamente o raciocínio de Medawar, anteriormente comentado.

Ao pensar em efeitos de um mesmo gene em idades de manifestação possivelmente distintas, no entanto, Williams propôs que a medida da magnitude de cada efeito em questão (vantagem ou desvantagem) será dada por

$$
S_{n}=m_{n} p_{n}
$$


onde $S_{n}$ é o efeito em questão, $m_{n}$ é a magnitude do efeito de $S_{n}$ e $p_{n}$ é a proporção relevante da probabilidade reprodutiva média para indivíduos da idade em que $S_{n}$ se manifesta.

Isto permitiu a reescrever a equação 2.18 considerando o efeito da estrutura etária no coeficiente seletivo final para o gene pleiotrópico:

$$
W=\left(1+m_{1} p_{1}\right)\left(1+m_{2} p_{2}\right) \ldots\left(1+m_{n} p_{n}\right)
$$

Desta equação podemos tirar o caso mais simples: um gene pleiotrópico com um efeito deletério relativamente tardio e um efeito bastante precoce. Para demonstrarmos a fórmula necessitamos saber os valores de $p$ para cada idade.

Imaginemos uma população (estruturada por simplicidade em uma escala humana), com natalidade e mortalidade constantes. Isto é necessário para não criarmos um argumento ad hoc: partiremos de uma população sem características senescentes e portanto com mortalidade constante, mas obviamente a existência de senescência, com mortalidades crescentes, não inviabiliza em nada o modelo.

Digamos que esta população tenha uma mortalidade constante de 0.25 a cada extrato etário de 4 anos, ou seja, de 0.0625 ao ano, e que este extrato seja composto de 1000 indivíduos. A pirâmide populacional será representada pela Figura 2.12. Nota-se a familiaridade desta pirâmide com qualquer população selvagem ou mesmo com populações humanas expostas a altas mortalidades (a título de comparação, a Figura 2.13 mostra a distribuição etária da população do Afeganistão, um dos países com as menores expectativas de vida, em 2008).

Nesta população não senescente, os organismos não perdem fertilidade com a progressão da idade e todos os indivíduos possuem a mesma probabilidade de reprodução. Portanto, o $p_{x}$, ou seja, a proporção da probabilidade de reprodução 


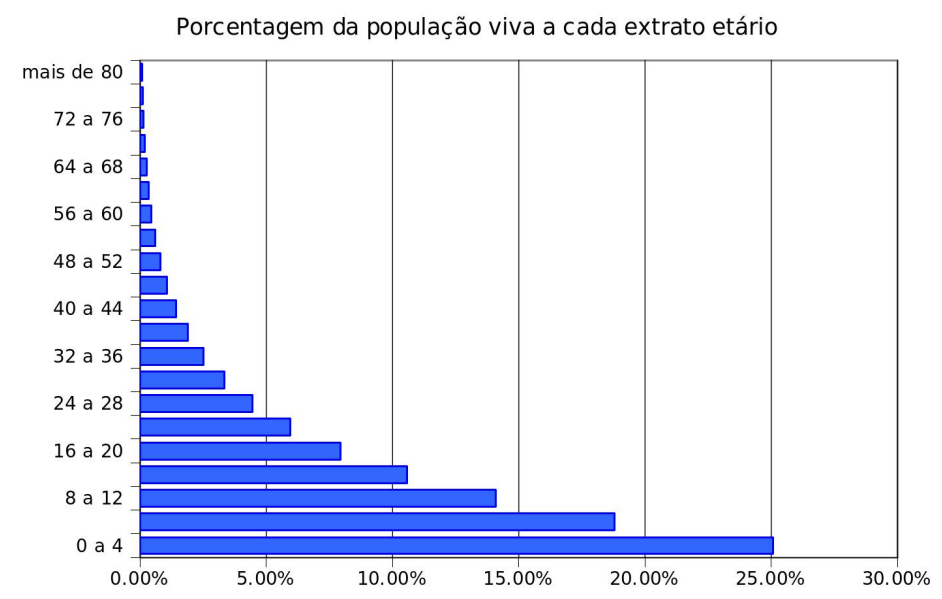

Figura 2.12 - Distribuição etária de suposta população não senescente exposta a uma mortalidade de $6,25 \%$ ao ano.

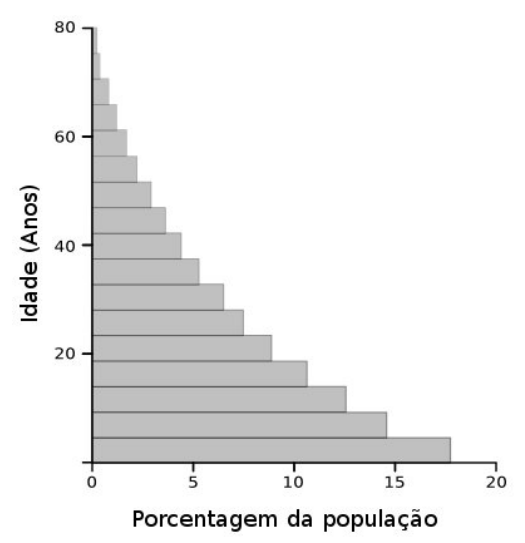

Figura 2.13 - Distribuição etária da população afegã em 2008 (dados do Censo dos EUA, International Database, disponível em http://www.census.gov/).

associada a cada idade será a proporção de indivíduos restantes na população, desde que o efeito $S$ em questão se mantenha após ativado, ou seja, é constante a partir de sua manifestação.

Podemos voltar ao nosso gene pleiotrópico simplificado: digamos que o primeiro efeito $S_{1}$ seja uma vantagem de início precoce, portanto expressa por um número positivo, de magnitude $m_{1}=1 \times 10^{-} 6$, e manifesta já no segundo extrato etário. Como $75 \%$ dos indivíduos sobrevive após os 4 anos, $p_{1}=0,75$, e $S_{1}=m_{1} p_{1}=7,5 \times 10^{-7}$. Consideremos agora o caso de um efeito deletério $S_{2}$ cuja magnitude, negativa, seja $m_{2}=-1 \times 10^{-5}$, ou seja um grau de magnitude acima. 
Caso este efeito se manifeste a partir dos 32 anos de idade, $S_{2}=m_{2} p_{2}=-7,29 \times 10^{-7}$. Aplicando a Equação 2.20, teremos que

$$
W=\left(1+7,5 \cdot 10^{-7}\right)\left(1-7,29 \cdot 10^{-7}\right)=1+2,06 \cdot 10^{=8}
$$

Claro que este coeficiente seletivo, sendo tão próximo de 1, é fracamente vantajoso, mas mostra como um efeito deletério tardio poderia ser sustentado por uma vantagem precoce dez vezes menos impactante. A idade que escolhi para este efeito deletério não é casual: em seres humanos, é uma idade em que desde a pré-história, pudemos encontrar um número significativo de indivíduos vivos (Caspari; Lee, 2004). Nesta população fictícia, tal gene afetaria 7,29\% de toda a população.

Williams conseguiu, assim, formular uma hipótese evolutiva para a permanência de efeitos deletérios cuja expressão fosse suficientemente precoce para serem notados em populações selvagens. Ressaltemos, no entanto, que nem esta equação nem o artigo clássico de Williams implica em nenhum momento nem o número de efeitos, nem quais serão precoces ou tardios. Embora fique evidente que o caso mais simples seja este, basta experimentarmos alguns números na Equação 2.20 para percebermos que esta implicação não existe, pelo menos do ponto de vista teórico, nem é sugerida por Williams: invertendo a situação experimentada anteriormente, será trivial concluir que genes com uma vantagem seletiva tardia, (porém grande), e uma desvantagem precoce, (porém pequena), poderão ter coeficientes seletivos maiores do que 1. Finalmente, desde sua formulação por Wright, e como fica evidente nas equações 2.18 e 2.20, os efeitos pleiotrópicos podem ser múltiplos, e não necessariamente 2 .

A literatura, no entanto, não acompanhou esta proposição. O antagonismo pleiotrópico de Williams passou a ser considerado =, como o caso em que um gene 
de 2 manifestações, uma vantagem precoce e uma desvantagem tardia, é selecionado positivamente. Vale a pena citar literalmente o conceito de pleiotropia antagônica encontrado no Handbook of Biological Aging, de 2006, no capítulo escrito pelo próprio editor do livro (Masoro, 2006):

Another genetic mechanism, proposed by Williams (1957), is referred to as antagonistic pleiotropy. It proposes that those genes that increase evolutionary fitness in early life will be selected for, even if they have catastrophic deleterious effects in late life. Again, the deleterious effects of these genes will be evident only in subjects in protected environments that enable a long life.

Enquanto Medawar discutiu a idade de início de uma característica deletéria e Williams ressaltou a magnitude dos efeitos gênicos, nenhuma das teorias discutiu a influência da magnitude da mortalidade extrínseca na seleção de genes deletérios, que faz parte do presente trabalho.

\subsection{A Teoria do Soma Descartável de Kirkwood}

A partir do final dos anos 1970, uma nova teoria sobre a evolução da senescência foi proposta por Thomas Kirkwood, raciocinando inicialmente não sobre mecanismos evolutivos mal-adaptativos como Medawar ou sobre genes pleiotrópicos de efeito total positivo como Williams, mas com uma firme base ecológica. Elaborando a partir da teoria da "catástrofe de erros" de Orgel (1963), Kirkwood nos ofereceu uma visão algo diferente daquilo que as teoria anteriores formularam sobre a evolução da senescência (Kirkwood; Holliday, 1975b, 1975a).

Kirkwood abordou a questão da senescência usando um argumento ecológico, em que os recursos energéticos poderiam ser alocados para a manutenção de células somáticas ou para a reprodução, gerando algum tipo de conflito soma-germe. Chamada teoria do soma descartável (a partir do original disposable soma), em úl- 
tima instância esta depende da existência de genes específicos que influenciam ou controlam a precisão do maquinário de duplicação / transcrição e tradução genético de uma forma idade-dependente. O próprio Kirkwood considerou sua teoria como uma especialização da pleiotropia antagônica de Williams (Kirkwood, 1977; Kirkwood; Holliday, 1979). A diferença é que Williams postula a existência de genes responsáveis por efeitos benéficos e maléficos, mas a teoria de Kirkwood, apesar de não negar a existência desses genes, não necessita deles. Se na teoria de Williams o balanço entre os efeitos positivo e deletério de um gene selecionaria alelos mutantes com a "combinação ideal" entre estes efeitos, na teoria de Kirkwood um único efeito genético, determinante da alocação de energia entre reprodução e manutenção do corpo seria suficiente para a evolução da senescência. Esta seria o resultado inevitável da seleção por um balança "ótimo" da alocação energética entre reprodução e manutenção do corpo.

Esta é a primeira teoria a propor que a evolução dos organismos possa otimizar a alocação de recursos metabólicos entre a manutenção da linhagem somática (o indivíduo em si) e os fenômenos de reprodução (o investimento na geração seguinte). Sob esta teoria, os mecanismos fisiológicos que lentificam o envelhecimento consomem recursos metabólicos, que se tornam menos disponíveis para a reprodução, e vice-versa. Como a reprodução da espécie é priorizada pela seleção natural, o corpo é "descartável" depois que sua função reprodutiva foi suficientemente cumprida, e os fenômenos de envelhecimento, então, aparecem. Há algum suporte experimental para esta teoria. Quando drosófilas são selecionadas para uma maior expectativa de vida, observa-se queda na fertilidade. Reversamente, a exposição de fêmeas à reprodução mais precoce diminuiu suas longevidades em relação às fêmeas virgens. Interessantemente, a observação feita de forma independente sobre o comportamento do hormônio juvenil concilia-se com este experimento ao ser reinterpretado como 
exemplo de oposição entre o investimento na manutenção do indivíduo ou em sua reprodução (Sgro; Partridge, 1999).

A teoria do soma descartável muda a pergunta fundamental sobre a evolução do envelhecimento: em vez de questionar por que senescemos, poderíamos questionar por que nós, humanos, vivemos tanto (Kirkwood; Rose, 1991).

\subsection{As teorias da senescência hoje}
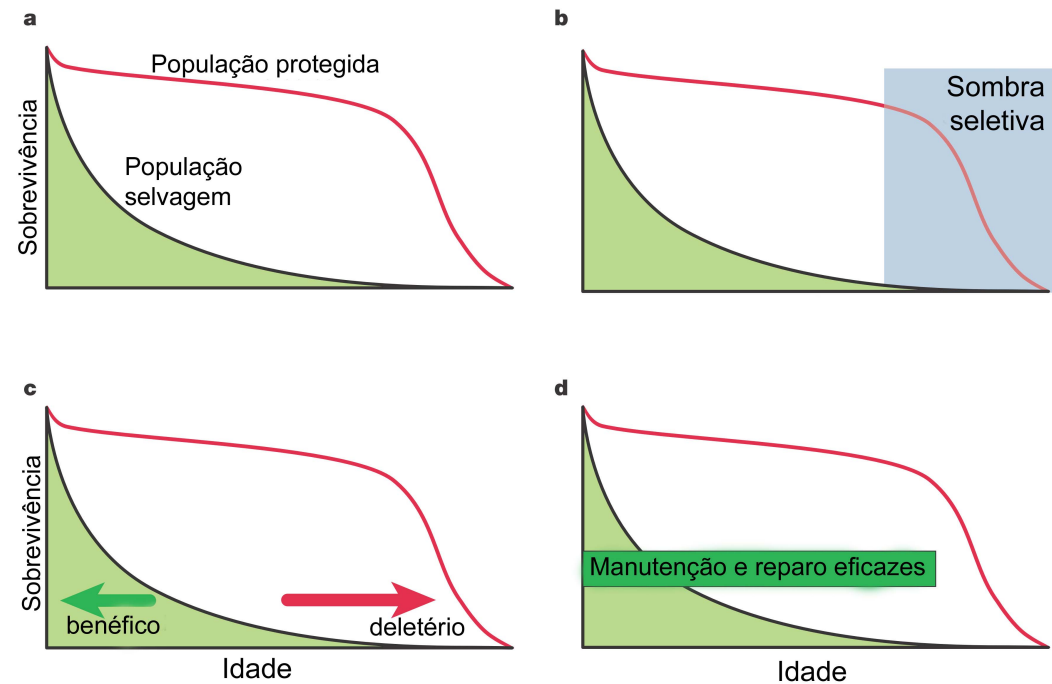

Figura 2.14 - Teorias evolutivas da senescência. Curvas típicas de sobrevivência em ambientes selvagens (áreas verdes) e protegidos (linha vermelha). (a) A mortalidade extrínseca existente em ambientes selvagens é alta o suficiente para tornar os indivíduos mais idosos bastante raros, minando qualquer idéia de a senescência possa ter evoluído como uma adaptação. (b) A natural raridade dos indivíduos idosos nestes ambientes faz com que a força de seleção natural caia com a idade; uma "sombra seletiva" nas idades mais avançadas pode permitir um acúmulo de mutações deletérias de efeito tardio (teoria do acúmulo de mutações). (c) Genes pleiotrópicos que levem a benefícios no início da vida podem ser favorecidos pela seleção, mesmo que tenham efeitos negativos em idades posteriores (teoria da pleiotropia antagônica); trata-se de uma simplificação; compare-se com a descrição da teoria na Seção 2.6. (d) A pressão seletiva para investir recursos metabólicos na manutenção e reparação somática é limitada: tudo que é necessário é manter o organismo em boas condições durante o tempo médio em que possa sobreviver e se reproduzir na natureza (teoria do soma descartável).

Extraído de (Kirkwood; Austad, 2000). 


\subsubsection{Qual é a arquitetura genética da senescência?}

Pelo termo arquitetura genética refere-se à base genética de um traço fenotípico. Além de compreender o mapa dos genes ligados a um determinado traço, a arquitetura genética considera todos os fenômenos através dos quais o mapa genético produz um determinado fenótipo.

A definição do fenótipo senescente é caracterizada em paralelo com a definição de senescência que empregamos ao longo do texto. Portanto, combina efeitos individuais (diminuição nas capacidades funcional e reprodutiva) com um efeito mensurável apenas populacionalmente (aumento da mortalidade idade-dependente). Isto em geral nos leva à conclusão de que é exatamente o mesmo fenômeno que nos torna individualmente mais frágeis e sob maiores riscos de morrer à medida em envelhecemos. A Figura 2.15 nos mostra que esta é apenas uma das possíveis relações entre a senescência fisiológica (queda progressiva na capacidade funcional e na reprodução) e a senescência demográfica (crescentes taxas de mortalidade) (Promislow; Fedorka; Burger, 2006).

Embora não esteja necessariamente clara qual a relação entre os componentes fisiológico e demográfico da senescência, a maioria dos "genes de envelhecimento" descritos na literatura são simplesmente genes cujas variantes influenciam na longevidade das espécies estudadas, independentemente de seu efeito fisiológico; poucos foram os genes cujas mutações mostraram alterar o MRDT das populações portadoras e, portanto o processo de senescência (de Magalhães; Cabral; Magalhaes, 2005). Adicionalmente, quando linhagens portadoras de muitos destes alelos longevos são misturadas com populações selvagens, em geral a mutação "benéfica" é perdida ao longo de poucas gerações, indicando que, embora tais genes aumentem a longevidade, eles exerçam algum efeito deletério para a aptidão (Promislow; Fedorka; 
Burger, 2006).

Por estas razões, a primeira decisão antes de buscarmos genes para a senescência deveria ser decidir qual modelo de senescência assumir. Do contrário, não saberemos interpretar os achados de forma coerente: uma mutação cujos portadores apresentem um incremento de 5\% em sua mortalidade anual a partir dos 30 anos de idade é uma doença genética ou um gene para a senescência? A Figura 2.15 mostra 3 possíveis relações lógicas entre as genéticas das senescências fisiológica e demográfica.

Caso entendamos que a senescência é um único fenômeno genético cujos efeitos fisiológicos levam aos seus aspectos demográficos (Figura 2.15 (a)), então os "genes da senescência" devem exercer um efeito deletério idade-dependente na fisiologia dos organismos e, por causa de tal efeito, aumentar a mortalidade a partir da idade de manifestação deste efeito.

Por outro lado, os genes que determinam efeitos na demografia da senescência podem exercer efeitos independentes na fisiologia dos organismos, sem que estes efeitos estejam ligados aos efeitos demográficos destes mesmos genes (Figura 2.15 (b)).

Finalmente, a senescência fisiológica poderia ser geneticamente independente da senescência demográfica, de tal forma que existisse uma "modularidade" genética entre ambos os fenômenos, em que distintos grupos de genes participem de cada processo (Figura 2.15 (c)). Isto não exclui, no entanto, a possibilidade de que a arquitetura genética da senescência compreenda todas as relações entre fisiologia e demografia descritas na Figura 2.15.

O presente trabalho parte da premissa de que genes ligados à senescência fisiológica possam impactar em aumento da probabilidade de morte (Figura 2.15 (a)). Para tal, apoia-se no fato de que há poucas evidências de que exista uma variabi- 

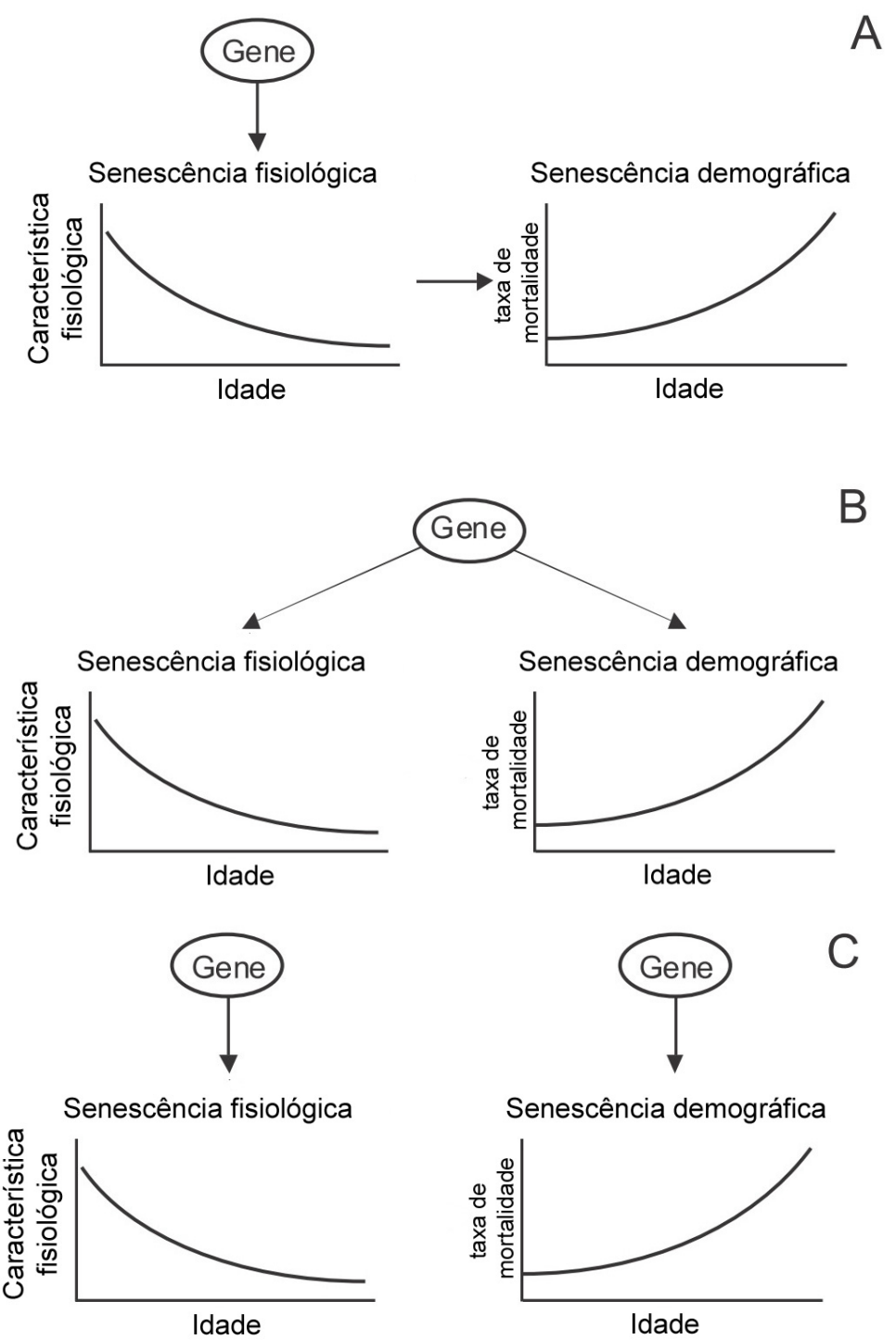

Figura 2.15 - Três diferentes modelos para a relação entre fisiologia e demografia na arquitetura genética da senescência. A figura representa três cenários possíveis: (a) Genes influenciam nos processos fisiológicos que, então, levam a efeitos crescentes na mortalidade idade-específica. (b) Os mesmos genes que levam à senescência nos processos fisiológicos independentemente determinam taxas crescentes de mortalidade, mensuráveis demograficamente. (c) Diferentes genes operam sobre a senescência em processos fisiológicos e demográficos. Extraído de Promislow, D. E. L. et al. Evolutionary Biology of Aging: Future Directions. In: Masoro EJ, Austad SN (Ed.). Handbook of the Biology of Aging. 6th. ed. San Diego: Academic Press, 2006. 217-242.

lidade genética para o declínio fisiológico idade-dependente sem que este influencie na senescência demográfica (Wessells et al., 2004) e na maior simplicidade desta 
modelagem.

Delimitado o fenótipo senescente, podemos rever alguns fenômenos genéticos que possam ter importância para a arquitetura genética da senescência. Tais fenômenos podem incluir:

- Epistasia, quando a expressão de um gene influencia negativamente a expressão de um outro;

- Poligenia, quando múltiplos genes contribuem com um traço fenotípico;

- Pleiotropia, quando múltiplas características fenotípicas são influenciadas por um único gene;

- Quase-continuidade, quando uma variação em um gene afeta minimamente um fenótipo;

- Plasticidade, quando um único genótipo pode produzir mais de um fenótipo distinto; tal multiplicidade fenotípica pode ocorrer entre indivíduos de mesmo genótipo, por ação de distintas influências ambientais sobre um mesmo indivíduo ou em um mesmo indivíduo em idades distintas;

- Evolvabilidade, quando variações genotípicas de um fenótipo existem em uma população e podem levar a distintos graus de adaptabilidade, de forma que modificações ambientais levarão a readaptações.

A epistasia poderia funcionar de forma análoga ao previsto na teoria da pleiotropia antagônica: supondo-se 2 genes com efeitos positivos para a aptidão, em que o primeiro gene exerça um efeito negativo sobre a expressão do segundo gene, teríamos um gene com efeitos positivos e negativos sobre a aptidão; o efeito sob a seleção, 
porém, seria o efeito médio. Da mesma forma, não há nenhuma violação teórica que impeça a existência de genes pleiotrópicos com efeitos antagônicos.

Acredita-se, desde a formulação da teoria do acúmulo de mutações por Medawar, que a senescência seja um fenótipo poligênico. De fato, nas últimas décadas temos visto a descrição de centenas de "genes da senescência" (Promislow; Fedorka; Burger, 2006). Aliado ao fato de que a senescência é um fenótipo de início precoce e progressão gradual na quase totalidade das espécies em que tem sido descrita, isto aponta para uma herança poligênica com quase-continuidade na resposta orgânica aos genes que determinam a senescência.

A plasticidade da senescência depende de qual medida tomemos para analisála: embora estímulos ambientais possam aumentar ou diminuir capacidade funcional, fertilidade ou mortalidade, se tomarmos o MRDT descrito por Gompertz como uma medida da intensidade da senescência, então este processo é pouco plástico: na nossa espécie, como mencionamos, diversos estudos têm mostrado um MRDT relativamente constante (Finch; Pike; Witten, 1990).

\subsubsection{Qual o papel da deriva genética na evolução da senescência?}

Vimos na Seção B.1.4 que, com todos os outros fatores iguais, espera-se maior efeito da deriva genética em populações com estrutura etária (em que $\left.N_{e}<N\right)$, do que em populações sem esta estrutura (em que $N_{e}=N$ ). Suponhamos que um efeito genético em uma população seja expresso em uma idade avançada (arbitrariamente definida como significativamente superior à idade de início reprodutivo de uma espécie). Podemos utilizar esta idade para dividir esta população em duas subpopulações: a de indivíduos que ainda não expressaram a característica e a daqueles que já a expressaram. 
Consideremos o que ocorrerá com a seleção nestas duas subpopulações. Logicamente, na primeira subpopulação, o gene com o efeito deletério é efetivamente neutro e, portanto, evoluirá exclusivamente por deriva. Na segunda subpopulação, há evolução por seleção. Nitidamente, o efeito da seleção para a população como um todo será menor do que ocorreria caso este mesmo gene se expressasse em idades menores. Esta é apenas uma outra maneira de dizer que a força de seleção cai com a idade.

Consideremos agora o efeito da deriva na segunda subpopulação: sendo uma fração da população total, seu $N_{e}$ será consideravelmente menor do que o $N_{e}$ da população inicial. Assim, além de estarem sujeitos a forças de seleção progressivamente menores em função da idade de manifestação, genes deletérios de manifestação tardia deverão estar sujeitos a fenômenos de deriva genética progressivamente mais intensos. Esta questão, não abordada nas atuais teorias sobre a evolução da senescência, é um dos objetos desta tese.

Desde o trabalho de Bidder (Bidder, 1932) e incluindo as primeiras teorias para a evolução da senescência (acúmulo de mutações, pleiotropia antagônica e soma descartável), o papel da deriva genética aleatória tem sido minimizado ou ignorado. Este viés reflete o pensamento evolutivo vigente na época e não incorpora os avanços na teoria evolutiva já descritos nas seções anteriores, que mostram que a deriva genética pode ter sido uma força evolutiva importante para o surgimento da variabilidade genética, bem como para o surgimento e desaparecimento de características em pequenas populações.

Este último aspecto torna fundamental o entendimento do papel conjunto da mutação, da seleção e da deriva na evolução da senescência, uma vez que a força da seleção cai com o avançar da idade justamente porque o tamanho das subpopulações 
diminui. Este é um dos enfoques do presente trabalho.

\subsubsection{Evidências empíricas para as teorias evolutivas}

Evidências para a base genética da senescência acumulam-se na literatura. Em Drosófilas, é possível obter-se duas linhagens distintas em relação à velocidade de instalação de sua senescência, através da separação sistemática, ao longo de gerações, da primeira (início da vida reprodutiva) ou da última ovoposição (imediatamente anterior à senescência). As moscas do segundo grupo senescem mais lentamente e vivem até 50\% maior do que as do primeiro grupo (Rose; Charlesworth, 1980, 1981; Luckinbill; Clare, 1985; Baret; Lints, 1993; Fukui; Pletcher; Curtsinger, 1995).

Segundo Rose, enquanto as moscas do grupo controle concentram sua maior eficiência no início da vida reprodutiva, as do grupo submetido à pressão seletiva necessitam da estratégia oposta. Em ambos os grupos, de acordo com a concepção evolutiva da senescência, mutações de manifestação tardia acumulam-se e propagamse para as novas gerações. Estas alterações não afetarão as moscas do primeiro grupo, mas sim as do segundo grupo, que beneficiar-se-ão se suas manifestações senescentes forem adiadas. Mutações que tornem efeitos deletérios mais tardios melhorarão a aptidão de indivíduos deste grupo, mas não do primeiro grupo. Este mecanismo, ao longo das gerações, faz com que as manifestações senescentes segundo grupo tornem-se ainda mais mais tardias, de modo que as moscas deste grupo evoluem maior longevidade. Interessantemente, mesmo com a suspensão da pressão seletiva, a diferença perdura e as linhagens de moscas oriundas destes experimentos se mantêm mais longevas do que as moscas selvagens (Rose, 1991).

Outra evidência genética para a senescência é a variabilidade genética para as velocidades de declínio nas taxas de sobrevivência idade-específicas (Hughes; 
Charlesworth, 1994; Promislow et al., 1996), bem como para a fecundidade idadeespecífica (Tatar et al., 1996). Além disto, existem evidências de que a variabilidade genética na longevidade é correlacionável com diferenças subjacentes na capacidade fisiológica (Djawdan et al., 1998; Gibbs; Chippindale; Rose, 1997). Como dissemos, sabe-se pouco sobre variabilidade genética especificamente para a velocidade de declínio idade-dependente nas reservas fisiológicas (Wessells et al., 2004).

Em relação às teorias específicas da evolução da senescência, evidências experimentais suportam cada uma das três teorias acima mencionadas (Hughes; Reynolds, 2005).

Hughes e outros encontraram evidências de acúmulo de mutações na evolução experimental de senescência acelerada (diminuição no MRDT) em drosófilas como o fenômeno predominante (Hughes et al., 2002), argumento sustentado por Cortopassi em relação à senescência humana (Cortopassi, 2002). A senescência fisiológica na nossa espécie, no entanto, é facilmente perceptível entre a quarta e quinta décadas. Isto não é incompatível com a observação de Medawar de que o acúmulo de mutações somente explicaria a senescência em populações artificialmente protegidas: o homem moderno é um excelente exemplo de população protegida.

Atualmente, diversos mecanismos pleiotrópicos têm sido descritos. O gene para o hormônio juvenil encontrado em espécimes selvagens de drosófila se expressa no início do ciclo de vida da mosca, e leva a aumento na fertilidade, aumento na vitelogênese e a maturação sexual precoce; por outro lado, prejudica a resistência a fatores de estresse, reduz a imunidade e reduz a expectativa máxima de vida (Flatt; Tu; Tatar, 2005). Em gansos, seleção (por intervenção humana) pela maturação sexual precoce provoca, como efeito adverso, mais senescência reprodutiva; análise quantitativa revelou correlação genética entre estas duas características (Charman- 
tier et al., 2006). Finalmente, diversos mecanismos conhecidos de morte celular programada em mamíferos executam também "importantes funções vitais, como a produção de energia, o metabolismo a diferenciação ou o ciclo celular" (Ameisen, 2004, 2005). Foi sugerido recentemente que a Doença de Alzheimer, que parece ser específica do homem, poderia ser um exemplo de pleiotropia antagônica (Bufill; Blesa, 2006).

Holliday defende que o ciclo de vida dos mamíferos ilustra fortemente a idéia do soma descartável: em todos os mamíferos observa-se uma relação inversa entre máximo potencial reprodutivo e máxima longevidade; os pequenos mamíferos são muito férteis e pouco longevos; os grandes mamíferos são menos férteis e muito longevos (Holliday, 1997, 2005). Esta contrapartida entre longevidade e reprodução também aparece na análise de uma coorte histórica de dados demográficos da aristocracia britânica em que se correlacionou a longevidade feminina com um menor número de filhos (Westendorp; Kirkwood, 1998).

Vale notar que as referidas teorias evolutivas do envelhecimento (acúmulo de mutações, pleiotropia antagônica, e soma descartável) não são mutuamente excludentes. Embora os três processos evolutivos atualmente aceitos para a evolução da senescência possam coexistir, um problema atual da pesquisa evolutiva em senescência é justamente saber o quanto cada um dos processos teria contribuído para o surgimento deste fenômeno (Gavrilov; Gavrilova, 2006).

Atualmente, a mortalidade extrínseca tem sido reconhecida como um importante fator na seleção entre distintas estratégias evolutivas: as estratégias de curta duração, com maturação sexual precoce e alta fertilidade e as estratégias de longa duração, com maturação sexual tardia e menor fertilidade compensadas pela produção de descendentes mais robustos e sob cuidado parental, por exemplo. O impacto 
da seleção de tais estratégias sobre a evolução da senescência é menos claro (Reznick et al., 2004).

Por fim, o papel da intensidade relativa da mortalidade intrínseca, ou seja, da intensidade do efeito deletério sob seleção em relação à mortalidade extrínseca não tem sido discutido e é, a nosso ver, desconhecido. Mais recentemente, um modelo matemático de pleiotropia antagônica prediz a evolução de aumento na mortalidade intrínseca (senescência) pelo aumento da mortalidade extrínseca (Williams; Day, 2003).

\subsubsection{A senescência contribui com a mortalidade na vida selvagem?}

Alguém morre de velho? A existência da senescência em populações selvagens em seus habitats, que, como mencionado, motivou Medawar e Williams a pensar na pleiotropia antagônica, foi questionada duramente na literatura por pesquisadores influentes, como Comfort e Hayflick (Comfort, 1956; Hayflick, 2000).

Em um amplo estudo, no entanto, Promislow descreve evidências significativas de senescência em 26 espécies de mamíferos in natura (Promislow, 1991). De fato, nos últimos anos, diversos estudos têm demonstrado senescência atuarial (Austad, 1993; Bronikowski et al., 2002; Ericsson et al., 2001; Orell; Belda, 2002) e reprodutiva em mamíferos e aves nos seus habitats (Saino et al., 2003; Reid et al., 2003; Austad, 1993; Ericsson et al., 2001; Broussard et al., 2003).

Finalmente, vem da nossa espécie um forte indício de que a senescência populações selvagens existe: se os dados coletados por Gompertz e aqueles que 
o sucederam são extrapoláveis para o homem primitivo, então nossa mortalidade entra em regime gompertziano por volta dos 12 anos. Senescência em uma idade tão precoce certamente teria impactado na mortalidade do homem primitivo. Devemos mudar a pergunta de alguém morre de velho para "alguém morre por causa da senescência'?" E a resposta, respaldada em ampla literatura é um sonoro sim (Carey; Judge, 2000).

\subsubsection{Perspectivas}

Durante décadas, pesquisadores no campo da senescência dividiram-se entre os propositores das teorias proximais, ou mecanicistas e os propositores das teorias distais ou evolutivas (Masoro; Austad, 2006). Felizmente, as últimas décadas têm demonstrado uma excelente percepção da importância do raciocínio conjunto entre "mecanicistas" e "evolucionistas": cada vez mais estudos focados na evolução da senescência buscam entender a instalação e evolução dos mecanismos de envelhecimento já descritos, e cada vez mais estudiosos destes mecanismos têm procurado entender a base teórica evolucionária necessária para sua compreensão (Masoro; Austad, 2006, Prefácio).

O estudo evolutivo da senescência busca explicar por que este fenômeno existe, oferecendo aos pesquisadores mecanicistas insights sobre quais poderiam ser as causas proximais da senescência e como a genética produz o fenótipo senescente (Kirkwood; Austad, 2000). Afinal, "nada faz sentido em biologia que não à luz da evolução" (Dobzhansky, 1973). 


\subsection{Estudando a evolução através de simulações matemáticas e computacionais}

Modelos matemáticos no estudo da evolução não são novidade, pois têm sido utilizados desde o surgimento da genética de populações, como os grandes trabalhos a época, notadamente por Wright ou Fisher, comprovam. Grandes avanços, como o entendimento evolucionário do altruísmo por Hamilton, se valeram de modelagem matemática e cálculos que mostraram em que circunstâncias o altruísmo (exemplificado em indivíduos que sacrificam suas vidas ou oportunidade reprodutiva em prol do benefício de muitos indivíduos aparentados) poderia ter natureza adaptativa.

Tais modelos matemáticos procuram soluções analíticas que possam prever o comportamento evolutivo de populações diante do fenômeno em estudo a partir de um conjunto de parâmetros e condições iniciais previstas pelas hipóteses em avaliação. A coerência dos resultados modelados a partir das hipóteses com os achados empíricos fortalece e ajuda a entender os processos em análise. Frequentemente, no processo de modelagem, nota-se que um parâmetro teoricamente tido como importante não influencia significativamente os resultados do modelo. Em outras situações, os modelos não funcionam adequadamente até que se agregue a eles parâmetros tidos como não-essenciais ao processo em estudo.

Uma maneira intuitiva de garantir a capacidade de previsão de um modelo e evitar erros é a modelagem baseada na realidade. Por este conceito, procura-se incluir no modelo o maior número possível de aspectos ou parâmetros em relação com a realidade do fenômeno em estudo. Possivelmente este modelo será capaz de obter os melhores resultados possíveis em termos da previsão de comportamentos ligados ao fenômeno em estudo. Alternativamente, os modelos simplistas procuram o menor número possível de parâmetros que possam prever de forma aceitável, o 
comportamento em estudo. Sobre estas duas correntes de modelagem, Silveira nos traz o interessante argumento do rato-canguru de Maynard Smith (Silveira, 2006).

A capa de seu clássico Mathematical Ideas in Biology, que reproduzimos na Figura 2.16, traz a ilustração caricata de um rato-canguru, com ênfase na massa $m$ do rato, representada por um retângulo hachurado, no comprimento de sua perna, representada por $d$, e na altura $h$ de seu salto. Neste modelo simplista, a altura do salto depende apenas do peso $m g$ do rato, onde $g$ é a aceleração da gravidade, do comprimento $d$ de sua perna e de uma constante $T$. A equação que descreve a altura (h) do salto do rato-canguru é, simplesmente (Silveira, 2006):

$$
h=\frac{T d}{m g} .
$$

Como Silveira discute, um modelo mais realista deveria descrever melhor os aspectos mecânicos do rato, considerando ao menos os movimentos articulares do animal, além de fatores ambientais, como a resistência do ar. Se bem concebido, possivelmente o modelo realista fará melhores previsões sobre o comportamento do sistema. No entanto, modelos detalhistas têm desvantagens: inicialmente, a menos que algo essencial tenha sido esquecido, a previsão de um modelo simplista deve coincidir razoavelmente com as observações reais. No entanto, o desenvolvimento e o cálculo do modelo simplista são mais fáceis. A segunda desvantagem é mais séria: modelos realistas não nos ensinam quais são os componentes fundamentais para a altura do salto do rato, ao passo que o modelo simplista nos ensina que a "altura de seu salto depende fundamentalmente do comprimento da perna do animal e do seu peso".

Penso que a decisão entre modelos simplistas ou realistas dependa, pelas razões discutidas, do propósito do modelo. Modelos cuja finalidade é a previsão 
devem ser o mais realista possível, pois seu desempenho será julgado pela acurácia de suas previsões. Um exemplo quotidiano seria um modelo computacional de previsão do tempo para notícias meteorológicas: seu grande propósito é, simplesmente, prever o tempo o mais precisamente e com maior antecedência possível. Por outro lado, modelos destinados a entender um fenômeno são melhor concebidos da forma mais simples possível, para captar os parâmetros essenciais do fenômeno que estudamos.

Assim, a criação de um modelo simplista não deve ser entendida como um processo linear desde o estudo teórico, a concepção e a confecção do modelo: frequentemente o processo de modelagem e teste do modelo nos tornam claro que um parâmetro deixado de lado é essencial ou que um incluído não é.

Acompanhando a ideia de modelagem desde os primeiros computadores, que foram inicialmente utilizados para execução de cálculos dos modelos matemáticos, a própria Biologia tem se tornado uma ciência da informação, como resultado do desenvolvimento da genômica como uma poderosa ferramenta de estudo evolutivo. A capacidade de responder questões relacionadas a aspectos moleculares de doenças ou da nossa fisiologia com base na genética evolutiva está diretamente ligada à nossa capacidade de adquirir, armazenar e interpretar grandes quantidades de dados. Nesta evolução da Biologia, os próprios computadores, cada vez mais poderosos em memória e processamento, tornaram-se fundamentais.

Outro importante progresso tem ocorrido na percepção da comunidade científica a respeito do papel que a modelagem pode ter nos diversos campos evolucionários. Muitos cientistas ainda entendem os modelos computacionais como essencialmente descritivos e, portanto, sem importância, pois, neste raciocínio, as respostas científicas fundamentais só poderiam ser obtidas em estudos experimentais. Outra crença extremamente arraigada é que, assim que um modelo necessite 
de 2 ou 3 parâmetros, ele pode "explicar qualquer coisa", resultando em uma descrença de sua utilidade real (Kirkwood et al., 2006). O diálogo nos últimos anos entre especialistas em modelagem e especialistas em biologia experimental, no entanto, tem levado a uma diminuição destes preconceitos. O resultado é a emergência de uma nova disciplina, a Biologia Sistêmica, que estuda a interação complexa dos diferentes componentes da vida nos diferentes níveis, do molecular ao ecológico, e sua importância no entendimento dos sistemas vivos.

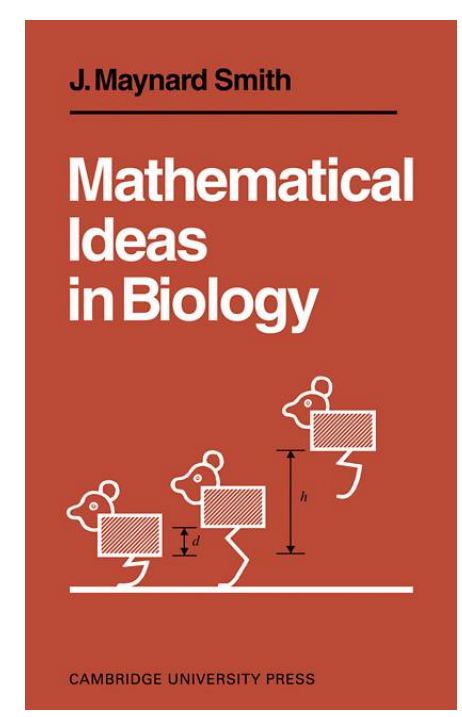

Figura 2.16 - O salto do rato canguru. Capa do livro Mathematical Ideas in Biology, de J. Maynard Smith, Cambridge University Press, 1a Ed.. 1968

Este tipo de abordagem para o estudo da vida tem-se desenvolvido por uma série de razões. Em primeiro lugar, como resultado do desenvolvimento da genômica (causado pelo progresso nas técnicas de sequenciamento genético e estudo de expressão genética, bem como no processamento dos dados obtidos) e da ciência pós-genômica (causado nos avanços da proteômica e do estudo de dados sobre a função celular), a própria Biologia tem se tornado cada vez mais uma ciência da informação.

Em segundo lugar, nos últimos anos a literatura tem enfatizado progressi- 
vamente a percepção de que processos biológicos complexos não serão entendidos através da aplicação de técnicas experimentais cada vez mais reducionistas e pontuais sem uma visão de conjunto. Não há como prescindir de uma integração destes dados detalhados em uma análise "sistêmica", que permita um conhecimento de como cada componente detalhado por estudos experimentais interage em conjunto e de quais são as propriedades emergentes destas interações.

Finalmente, o progresso no poder de armazenamento e processamento de computadores pessoais tem tornado possível realizar em computadores da universidade ou no laboratório simulações com um grau de sofisticação que teria demandado o uso dos antigos e caros computadores "mainframes" por muito dias de processamento. Isto tornou possível o uso de simulações sérias e complexas acessível a um número muito maior de cientistas, especialmente aqueles não diretamente ligados à computação e que antigamente não teriam à disposição poder computacional suficiente para tanto. A interação resultante do aumento no número de cientistas que se dedicam ao estudo de fenômenos biológicos e especialmente evolutivos, principalmente de cientistas das áreas biológicas, tem levado a um progresso ímpar nos últimos anos.

Ao mesmo tempo que este progresso se operou, tem se construído uma nova percepção no meio acadêmico em geral sobre o papel e o valor da utilização da modelagem computacional na pesquisa biomédica. Durante muitos anos, para muitos cientistas da área biomédica que nunca trabalharam diretamente com modelagem, o papel e a potencial contribuição deste conjunto de técnicas não foi claro. Muitos ainda hoje enxergam os modelos computacionais como puramente descritivos, de forma que questionam por que alguém deveria gastar tempo com elas se os dados reais só poderão ser revelados por experimentação biológica. Outros ainda acredi- 
tam na falsa ideia de que um modelo matemático possa simplesmente se acomodar a qualquer teoria desde que tenha 3 ou mais variáveis, resultando em um ceticismo em relação a estudos envolvendo simulações computacionais (Masoro; Austad, 2006, Capítulo 8).

Ao contrário de constituir uma técnica sem poder de previsão, a modelagem computacional de um processo biológico com atenção rigorosa traz uma série de vantagens não necessariamente compartilhadas por todos os desenhos experimentais:

1. O primeiro passo na construção de um modelo é a explicitação verbal conceitualmente correta do problema e das hipóteses em estudo, para a seguir especificar todos os elementos do modelo e como estes interagem entre si; somente a seguir se pode partir para a formulação matemática;

2. No processo de formulação matemática de um modelo, eventuais vazios no conhecimento teórico podem ficar explícitos; estes vazios talvez necessitem de novos experimentos ou talvez possam justamente ser determinados por simulações;

3. Modelos computacionais podem levar a resultados qualitativos ou quantitativos; estudos em que previsões quantitativas sejam possíveis poderão levar a testes de hipóteses mais rigorosos; por exemplo, para uma dada hipótese que tenha sido reforçada por resultados experimentais, um modelo poderia mostrar que a magnitude dos efeitos achados experimentalmente é pequena demais para poder explicar por si só um determinado efeito; isto é de particular importância no estudo da senescência, em que múltiplos mecanismos e hipóteses se somam para a produção deste fenômeno;

4. Finalmente, a modelagem computacional pode levar ao desenho de melho- 
res abordagens experimentais, especialmente quando interações complexas são prováveis: a complexidade é extremamente difícil de se lidar experimentalmente, mas é diretamente abordada em modelos computacionais (Masoro; Austad, 2006, Capítulo 8).

Para aquele que não lida diretamente com modelagem computacional ou matemática e não está habituado com a literatura da área, a modelagem biológica pode parecer envolver um mesmo conjunto de ferramentas para abordar os aspectos biológicos mais distintos. Habilidade matemática, conhecimento de uma linguagem de programação e um pequeno grau de conhecimento biológico pareceriam suficientes para a proposição de um modelo. Nada mais falso: sem uma forte base de conhecimento biológico, é impossível abordar com modelagem, de forma útil, um determinado problema. Mais: para desenhar um experimento de laboratório, além do conhecimento profundo sobre o problema, o cientista precisa decidir qual sua hipótese, quais são as variáveis em estudo e quais explorar sob quais diferentes valores; usualmente, grande parte do tempo de trabalho será gasto no estudo dos controles, para reduzir a possibilidade de artefatos; já realizado o estudo, o cientista de laboratório terá de tomar muito cuidado na interpretação dos seus resultados e na tomada de conclusões que não extrapolem o poder de suporte de seus resultados. O mesmo se aplica para o cientista que modela (Hilborn; Mangel, 1997).

Talvez a razão para esta descrença, aliada à falta de contato com a modelagem, esteja no fato de que há algo de semelhante a todos os modelos computacionais: em todos eles, um programa de computador recebe uma entrada de dados (normalmente as variáveis em estudo ou o estado inicial de um sistema, molecular, biológico ou ecológico que se pretende estudar), executa um processamento sobre estes dados com regras pré-definidas e devolve um conjunto de resultados ao pesquisador, que 
os interpreta. Esta enorme semelhança na primeira leitura de um artigo que descreva um trabalho de simulação pode levar à crítica abordada acima. No entanto, na área da biologia evolutiva, muito antes de os primeiros modelos computacionais aparecerem, foram os modelos matemáticos da genética de populações que fizeram o conhecimento avançar. Nestes modelos, muitos determinísticos e outros estocásticos, um determinado conjunto de dados era submetido a análises estatísticas e conjuntos de equações que permitiam um tratamento matemático do conhecimento teórico, para chegar a resultados e conclusões que, em seu conjunto, definiram a moderna ideia de evolução.

Em verdade, a enorme contribuição da matemática à biologia evolutiva foi acompanhada do próprio desenvolvimento da moderna estatística pelos mesmos biólogos que ajudaram a construir a moderna síntese evolutiva (Seção B.1.0.4), como Hamilton, Wright e Fisher, este último o criador do famoso "teste-F de Fisher". O próprio autor da teoria do acúmulo de mutações, Medawar, ao raciocinar sobre uma população fictícia de tubos de ensaio submetidos a uma mortalidade extrínseca (Medawar, 1952) e concluir que esta teria uma estrutura etária, estava fazendo uma simulação mental de um processo evolutivo. Como se vê, em verdade a modelagem nunca esteve afastada do desenvolvimento da biologia.

Felizmente, o diálogo entre pesquisadores originalmente das áreas biológicas e aqueles das áreas da computação e o progresso dele resultante está levando ao fim desta visão errônea. Deste diálogo, uma nova disciplina foi proposta, a biologia sistêmica, que busca integrar conhecimentos pontuais obtido em genética e fisiologia em uma visão sistêmica e ecológica (Kitano, 2001). Embora a biologia sistêmica se apóie constantemente na computação, seja nas mais sofisticadas simulações e modelagens, seja para o armazenamento e processamento de dados coletados em 
ensaios biológicos, esta retoma o conceito proposto nos anos 1920 por Paul Weiss e Ludwig Bertalanffy, que pregavam uma abordagem chamada de "teoria sistêmica da vida", que, entre elas a concepção de seres vivos como sistemas organizados, sob hierarquia entre indivíduos e se relacionando sob um ecossistema (Drack; Apfalter; Pouvreau, 2007).

Modelos computacionais são úteis para a abordagem de sistemas complexos por várias razões e há duas formas básicas para construí-los. A abordagem indutiva apenas necessita conhecer o comportamento de um sistema ecológico, e é mais útil para a obtenção de modelos de predição de resultados. Por exemplo, se sabemos quais sinais antecedem uma tempestade e qual o grau de associação de cada um deles com o evento final (tempestade), podemos construir um modelo preditivo de tempestade com base nos sinais que a antecedem. Tal modelo eventualmente poderá predizer o aparecimento de tempestades com grande precisão, sem que sequer saibamos por que um determinado tipo de vento associado com um certo grau de umidade relativa do ar leva a chuva. Na verdade, tais modelos são experimentos descritivos, em que o sistema pesa os dados de entrada e descreve a saída provável deste conjunto de entradas.

Em contraste, a abordagem dedutiva precisa do melhor entendimento possível dos fatores envolvidos em causa e efeito do assunto em pauta, mas tem a vantagem de gerar modelos exploratórios dos mecanismos operacionais envolvidos (Hoffmann, 2005, 2006). Estes últimos, a cuja categoria pertence a proposta presente, são formados por um processo de tentativa e erro na criação de modelos, através de simulações que guiam o pesquisador e permitem separar quais dentre os fatos conhecidos sobre um assunto são causas e quais são efeitos resultantes da própria dinâmica do sistema, bem como quais fatores são relevantes para os resultados e 
quais são fatores de confusão. Experimentos dedutivos, especialmente sobre problemas complexos, podem levar a resultados não triviais, como a quantificação da importância de um determinado fator na gênese de um dado fenômeno.

Assim, um modelo computacional dedutivo já validado presta-se a ensaios computacionais experimentais, em que a entrada do sistema são as variáveis consideradas importantes pela teoria, o processamento de dados do sistema ocorre segundo as regras ditadas pela teoria que ele investiga e a saída do sistema são os resultados do ensaio, que poderão ser confrontados com as previsões da mesma teoria e com os resultados e achados experimentais. Deste confronto pode surgir um refinamento do modelo, o desenho de novos estudos ou mesmo uma inferência, positiva ou negativa, sobre a teoria, que poderá se acrescentar, de forma Bayesiana, à credibilidade da própria teoria em investigação.

Outra clara vantagem da utilização de modelos computacionais em estudos evolutivos é a possibilidade de estudar dinâmicas evolutivas que possam tomar centenas ou milhares de gerações, as quais, se estudadas in vivo, poderiam necessitar de um tempo impraticável. O advento de computadores com progressivamente maior capacidade de processamento e armazenamento de dados tem permitido modelos computacionalmente mais dispendiosos e a simulação de maiores números de ciclos evolutivos ou gerações em menor tempo.

A utilização de simulações no estudo evolutivo é especialmente útil para o estudo da senescência. Sabemos que, embora mutações e o efeito da deriva genética aleatória atuem diretamente nas frequências genéticas de uma população, o mesmo não se dá com a seleção. Uma vez que a seleção atua sobre fenótipos, que são o produto do binômio ambiente-genoma, modelos animais em laboratório não necessariamente serão submetidos às mesmas pressões seletivas. 
Especificamente em relação à senescência, linhagens animais adaptadas ao laboratório (que são os modelos geralmente utilizados pelos pesquisadores, que não capturam populações selvagens a cada estudo) tendem tipicamente à maturação reprodutiva mais precoce, a apresentar maior fecundidade no início da idade reprodutiva e a ter expectativas de vida mais curtas do que indívíduos selvagens em seus habitats naturais (Houle; Rowe, 2003; Miller et al., 2002). Estas alterações podem ser resultado de adaptação às diferenças entre os ambientes selvagem e laboratorial. Linnen vai além: sugere que os alelos mutantes descritos em várias espécies em laboratório que têm sido associados à longevidade poderiam estar agindo unicamente no sentido de retomar no ambiente de laboratório a longevidade "natural" destas espécies (Linnen; Tatar; Promislow, 2001). Uma vez que o estudo da senescência em laboratório tem um grande potencial de introduzir inadvertidamente tais artefatos, a existência de modelos computacionais pode auxiliar no desenho e na interpretação dos estudos de laboratório.

\subsubsection{Modelos computacionais no estudo evolutivo}

\subsubsection{Algoritmos evolutivos}

Tipicamente, modelos computacionais aplicados a problemas de física ou engenharia são usados para a busca de uma solução para um problema que envolva múltiplas variáveis e tenha dinâmica complexa. Para isto, utilizam algoritmos evolutivos, programas que lançam mão de processos inspirados na evolução: reprodução, mutação, crossover (quando cabível) e seleção, em geral através de iterações ou ciclos repetidos com o esquema básico (Koza, 1992):

1. formação de uma população inicial de indivíduos;

2. medida da adequação de cada indivíduo; 
3. seleção dos melhores indivíduos;

4. reprodução destes indivíduos com variações (mutações, rearranjos, crossovers, etc.);

5. critério de término: se não foi ainda atingido, retorna-se primeiro 2 .

Cada indivíduo é um conjunto de condições ou variáveis (genoma) que representa uma tentativa de solução para o problema em investigação. A população de indivíduos é, inicialmente, gerada aleatoriamente ou com uma condição inicial adequada. O critério de término das iterações pode ser o encontro de uma solução ou um número pré-estabelecido de iterações. No primeiro caso, entende-se por solução o encontro de um ou mais indivíduos que atenda(m) um critério de solução pré-estabelecido ou permita(m) ao modelo reproduzir observações experimentais. Alternativamente, considera-se como solução o melhor indivíduo ou o grupo de indivíduos na última iteração (Koza, 1992).

Há, porém, uma importante diferença entre o encontro da solução de um problema de engenharia e uma investigação sobre um problema evolutivo. No segundo caso não há um término pré-definido: em teoria, um sistema poderia evoluir indefinidamente, pois não há necessariamente uma solução ideal. Em princípio, uma nova mutação sempre poderá conferir maiores vantagens ao seu portador.

Podemos dividir sumariamente os algoritmos evolutivos em: estratégia evolutiva, neuroevolução (com o uso de redes neurais artificiais), programação genética, programação evolutiva, e algoritmos genéticos. Destes, os três últimos têm sido os mais utilizados na abordagem de problemas biológicos evolutivos (Koza, 1992).

O que diferencia estas três últimas técnicas de construção de algoritmos evolutivos é como se constroem os indivíduos sob evolução aqui chamados também de organismos artificiais. 


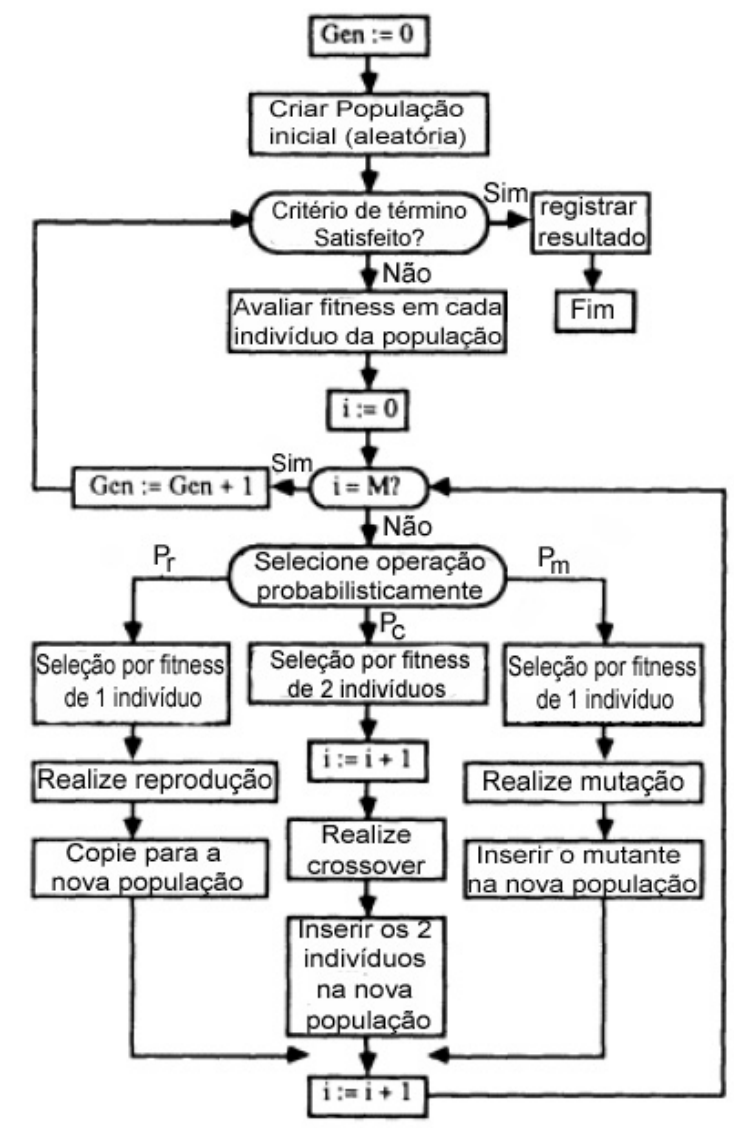

Figura 2.17 - Fluxograma típico de um algoritmo genético. Extraído de Koza (1992).

Na programação genética, os indivíduos são programas de computador executados sob um programa-mestre (plataforma) Diferentes programas gerados a partir de programas "pais" oferecem soluções para um determinado problema, digamos, um problema de lógica. O grau de adequação da solução constitui a aptidão de cada programa. Com base nos valores de aptidão, uma fração dos programas é removida e os programas "sobreviventes" se reproduzem. Neste ponto podem ocorrer mutações e os programas resultantes apresentam variações em seus códigos e, possivelmente, na adequação de suas soluções. O processo é repetido por um número em geral grande de iterações e o resultado da simulação em geral são os programas (ou as soluções) desenvolvidos. 
Na programação evolutiva os indivíduos também são programas de computador, porém o código destes programas é fixo e se permite que um conjunto de parâmetros de cada programa possa sofrer mutações e pressões seletivas a cada iteração.

Nos algoritmos genéticos, por sua vez, os indivíduos são conjuntos dos parâmetros de simulação e de variáveis euxiliares, controlados dentro de um único programa de computador. Os parâmetros definem todos os aspectos que sejam considerados importantes para o modelo em questão. Variáveis auxiliares são aquelas utilizadas para manter registros dos indivíduos, sem estarem sujeitas ao processo evolutivo. Por exemplo, um indivíduo por ser formado por seu genoma, que contém os parâmetros sob estudo, e sua idade, posição e gênero. É neste ponto, em que o pesquisador decide quais parâmetros e variáveis comporão os indivíduos, que deve-se pensar na abordagem, que pode ser simplista ou integral.

A utilização de organismos artificiais permite a modelagem de uma arquitetura genética representativa do fenômeno em estudo e sujeita a mutações durante o processo de reprodução (ou até mesmo poderia simular mutações somáticas, por exemplo). Os organismos podem se replicar em um ambiente virtual, que pode ser uma matriz geométrica cujos parâmetros de localização são computados em cada indivíduo, bem como pode-se optar por não haver nenhum parâmetro localizatório. Como sempre, tudo depende do que é essencial especificamente para o problema a ser estudado.

Uma das primeiras plataformas computacionais amplamentes aceita pela comunidade científica para o estudo da evolução no computador, a plataforma Avida, foi desenvolvida a partir de 1992. Utilizando a técnica da programação genética, a plataforma Avida é um programa sob o qual programas são executados. Estes 
programas fazem o papel dos organismos artificiais; em seu "código genético" estão todas as informações necessárias para que os próprios programas montem suas cópias, nas condições em que o experimento determine. Em geral, estes organismos digitais competem entre si por alíquotas de processamento e memória do computador em que a plataforma é executada. Novos programas com mutações espontâneas podem ser recompensados com espaço em memória e velocidade de processamento adicionais desde que preencham critérios pré-estabelecidos nas instruções iniciais de cada simulação.

A grande contribuição da pesquisa com organismos digitais, independente da técnica de modelagem (algoritmo genético ou evolucionário) é a rapidez de evolução entre gerações no computador, bem como o fato de que praticamente todos os parâmetros são controláveis ou monitoráveis de forma exata e sem erros de medição (O’neill, 2003).

Diversos problemas fundamentais em evolução têm sido estudados com o auxílio dos organismos digitais. A evolução morfológica, simbolizada pelo surgimento de instruções de deslocamento, bem como morfologias somáticas mais adequadas à captação de alimentos, foi demonstrada: em um ambiente computacional, organismos digitais evoluíram formas mais adaptadas ao padrão de "queda" de alimentos no ambiente, bem como no sentido de se moverem para onde os pesquisadores espalhavam o alimento (Silveira; Massad, 1998).

Em 1999 levantou-se a hipótese de que interações (epistasia) entre diferentes mutações genéticas produzindo efeito exponencialmente positivo na aptidão são comuns, surgindo espontaneamente nos organismos digitais expostos a mutações; o mesmo estudo sugeriu que organismos com aparato genético maior e mais complexo resistiriam mais aos efeitos de uma mutação deletéria, conferindo robustez ao 
genoma (Lenski et al., 1999).

Em 2003 foi documentado o surgimento espontâneo de características complexas - no caso, operações matemáticas complexas que surgiram a partir de organismos auto-replicantes originais que não realizavam nenhuma operação matemática (Lenski et al., 2003). Ao verificar que algumas das funções matemáticas mais complexas evoluíram através de trajetórias em que mutações deletérias intermediárias se mostraram fundamentais para a construção do genótipo capaz de executar as funções mais complexas, este trabalho lançou luz sobre como teriam surgido estruturas complexas, como os olhos, a partir de estruturas intermediárias sem função, uma hipótese não testável pelos meios convencionais em laboratório, dado o grande número de gerações necessário para tal observação.

Edlund e Adami mostraram em 2004 que organismos digitais expostos a altas taxas de mutação tendem a evoluir linhagens em que o efeito médio das mutações negativas é progressivamente menor (Edlund; Adami, 2004). Estudando efeitos da mudança de ambiente na evolução dos organismos digitais, Wagenaar e Adami demonstraram que organismos rapidamente perdiam os "genes"para operações matemáticas previamente evoluídos uma vez expostos a um novo ambiente em que estas operações (análogos das reações químicas) não geravam benefício (Wagenaar; Adami, 2004). A relação entre especiação (divisão de uma única linhagem em várias), a manutenção da diversidade das espécies em um determinado ambiente e sua ligação com os recursos deste ambiente foi estudada também em 2004 por Chow e colaboradores (Chow et al., 2004); em seu estudo, a diversidade de recursos de um ambiente (configurando a existência de mais de um nicho evolutivo) foi suficiente para permitir a especiação. 


\subsubsection{Simulações computacionais e a evolução da senescên- cia}

Há vários estudos utilizando este tipo de técnica nas últimas décadas. Simulações computacionais foram utilizadas para mostrar a emergência de padrões evolutivos de características deletérias compatíveis com o mecanismo do acúmulo de mutações. Dentre os estudos publicados, alguns não simulam a evolução da senescência, mas já determinam sua instalação ad hoc (Guillaume; Rougemont, 2006); outros, como o modelo introduzido por Tzafestas em 2001, simplesmente utilizam conceitos leigos sobre evolução e senescência, de forma que os resultados partem de premissas muito errôneas (Tzafestas, 2001).

Dentre estes modelos, destaca-se um modelo conhecido como "Modelo de Penna" para evolução da senescência (Penna, 1995). Este utiliza genótipos caracterizados por "cadeias de bits" em que mutações deletérias podem estar presentes ou ausentes do genoma; novos indivíduos herdam seu genoma dos indivíduos paternais e podem nascer com mutações em relação ao genoma paternal; cada gene na cadeia de bits é ativado, caso seja deletério, na idade correspondente a sua posição no genoma; a mortalidade intrínseca é representada pela ativação do número máximo $T$ de mutações que um indivíduo pode expressar e se manter vivo. No momento em que isto ocorre, o indivíduo é removido da população e contado como uma mortalidade genética. Para controle de população e para representar as causas extrínsecas de mortalidade, Penna utilizou o fator Verhulst, em que a mortalidade extrínseca $\left(\mu_{e}\right)$ é uma probabilidade de morte dependente da proporção entre a população total em um dado momento $t\left(N_{t}\right)$ presente em relação à população máxima, $N_{\max }\left(\mu_{e}=\frac{N_{t}}{N_{\max }}\right)$.

Este modelo é muito importante, pois ao nosso conhecimento, foi o modelo mais antigo a reproduzir, a partir do conceito de acúmulo de mutações, dinâmi- 


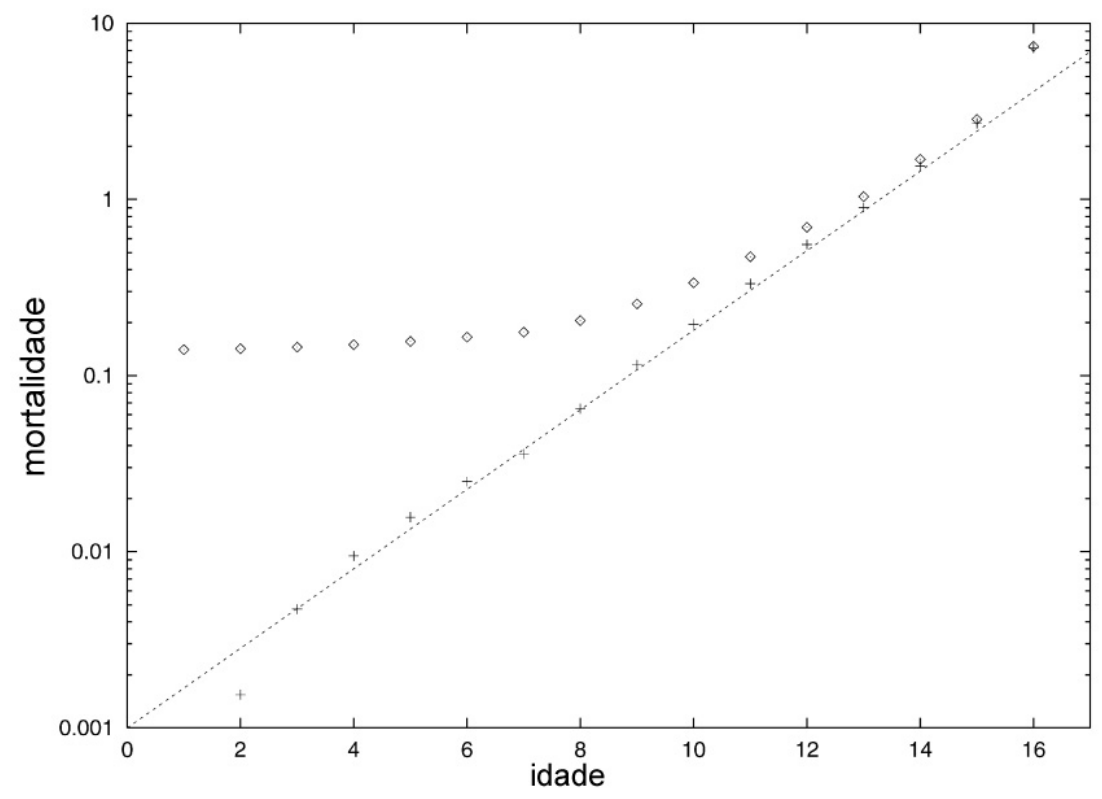

Figura 2.18 - Taxas de mortalidade em uma simulação com o modelo Penna para uma população haplóide e assexuada. O comportamento exponencial da mortalidade em função da idade fica evidente neste gráfico semi-log, pois aparece como uma reta. Isto é compatível com a lei de Gompertz desde o nascimento, quando se ignoram as outras causas de morte (cruzes) e, mesmo quando as mortes causadas pelo fator Verhulst são inclusas (losangos), a mortalidade passa a subir de forma exponencial aproximadamente a partir da idade 12. Parâmetros: $\mathrm{T}=3, \mathrm{R}=8, \mathrm{~B}=1, \mathrm{M}=1$ população inicial de cerca de 109 indivíduos. Extraído de Moss de Oliveira, Alves e Sa Martins (2000) Compare o traçado em losangos (mortalidade global) com o comportamento da mortalidade na população americana dos 30 aos 90 anos, na Figura 2.3.

cas de mortalidade compatíveis com as observações populacionais, como a "lei de Gompertz" (Seção 2.2).

No modelo Penna, as simulações evoluem em ciclos ou iterações computacionais e o tempo é medido em número de ciclos. O modelo trabalha sobre um pool de genomas, em que cada genoma simboliza um indivíduo, com idade registrada. Os indivíduos possuem genes que são listados sequencialmente em uma cadeia de bits, a qual constitui o genoma propriamente dito. Neste, os únicos genes representados são aqueles com efeitos idade-específicos, podendo ser deletérios (valor 1) ou neutros (valor 0). A idade de manifestação de um gene corresponde à sua posição sequencial 
no genoma, de forma que o primeiro gene está ativo no nascimento, o segundo no próximo ciclo e assim por diante. Por definição, o tamanho $S$ de bits do genoma corresponde à expectativa de vida máxima dos indivíduos em uma simulação. O número $A$ de mutações ativas em um indivíduo equivale, assim, à soma dos valores dos bits em seu genoma a partir do primeiro locus até aquele correspondente a sua idade atual.

A pressão seletiva é representada por um limiar de $T$ alelos deletérios ativos. Para cada indivíduo, sempre que $T=A$, ocorre morte por causas genéticas. A mortalidade extrínseca às causas genéticas é modelada com a utilização do fator Verhulst. Trata-se de uma probabilidade de morte que aumenta à medida em que a população se aproxima da população máxima que o ambiente pode sustentar. Tal probabilidade $V$, para um determinado ciclo $t$, é ser calculada no início do ciclo, através da razão:

$$
V_{t}=\frac{N_{t}}{N_{\max }}
$$

onde $N_{t}$ é a número de indivíduos no início do ciclo $t$ e $N_{\max }$ é o número máximo de indivíduos que pode sobreviver.

Após atingirem a idade reprodutiva mínima e até que atinjam a idade reprodutiva máxima, todos os indivíduos dão origem a $B$ novos indivíduos a cada ciclo. Tais indivíduos recebem cópias do genoma materno, passo em que podem ocorrer mutações, em que $M$ mutações são introduzidas em loci aleatórios. No modelo original as mutações somente poderiam ser deletérias, mas modelos em que mutações são aleatoriamente benéficas ou deletérias dão resultados semelhantes (Moss de Oliveira; Alves; Sa Martins, 2000).

Com base nestas premissas, uma simulação típica inicia com a integração da população inicial de $N$ indivíduos, sejam sem nenhuma mutação deletéria, sejam 
com um número aleatório de mutações, entre 0 e $S$, localizadas em loci determinados aleatoriamente. A partir da integração da população inicial, as simulações ocorrem por Nsteps ciclos, em que:

- Computa-se o fator Verhulst $(V)$;

- Para cada indivíduo, aumenta-se a idade em 1;

- Para cada indivíduo, se a idade é menor que sua idade programada de morte e se um número aleatório entre 0 e 1 é maior que $V$, então este se reproduz, dando origem a $B$ clones com $M$ mutações; em caso contrário, o indivíduo morre (Penna; Stauffer, 1995).

No último ciclo, medidas são feitas da população, o que constitui o resultado da simulação. Tipicamente, são medidas a distribuição etária da população, a probabilidade de sobrevivência em função da idade, as taxas de mortalidade da população e a distribuição genética da população (Moss de Oliveira; Alves; Sa Martins, 2000).

No entanto, este modelo merece algumas considerações: o fator Verhulst foi originalmente introduzido no intuito de evitar uma superpopulação de indivíduos que consumisse a memória do computador, uma vez que o modelo não prevê uma população máxima (Penna, 1995). No modelo Penna, é este fator de mortalidade que domina a dinâmica evolutiva assim que o estado estacionário é atingido (Cebrat, 1998). Isto não surpreende, pois concorda com a premissa da teoria de Medawar: são os fatores extrínsecos de mortalidade que formam a distribuição etária "ideal", porém já estruturada em idades, levando à perda na força de seleção nas idades avançadas. O modelo Penna, no entanto, não permite uma quantificação específica da mortalidade extrínseca.

O modelo Penna original também aborda a mortalidade genética como sendo determinística, uma vez que um indivíduo necessariamente morre quando atinge a 
idade em que terá ativos um número de genes deletérios igual ao limiar $T$. A menos que este indivíduo morra pelo fator Verhulst, ela já nasce marcado para morrer em uma determinada idade. Isto pode ser um bom modelo para uma doença genética, mas não para o processo de senescência, o qual é gradualmente deletério e de início precoce.

Embora os resultados deste modelo lancem luz sobre a dinâmica evolutiva subjacente à evolução da senescência demográfica (incidência de morte em função de grupos etários), não acrescenta informações acerca da senescência fisiológica (diminuição da capacidade vital e reprodutiva de indivíduos em função de sua idade).

Tais características não tornam possível investigar através deste modelo os efeitos de mutações apenas fracamente deletérias, que poderiam ocorrer sobre qualquer locus do genoma, bem como tornam muito difícil estudar o parâmetro mortalidade extrínseca, uma vez que, com a utilização do fator Verhulst, a modificação do tamanho populacional máximo também deverá modificar o tamanho populacional durante as simulações e em seu estado estacionário. Neste caso, dificilmente uma modificação linear no tamanho populacional máximo causará efeitos lineares na mortalidade extrínseca.

Um modelo que permitisse o estudo de diferentes níveis de mortalidades extrínsecas sobre a evolução de mutações deletérias, bem como diferentes níveis de efeitos deletérios e taxas de mutação sobre a evolução da senescência por acúmulo de mutações permitiria abordar de melhor maneira como a ocorrência espontânea de mutações deletérias com efeito idade-específico poderia permitir o surgimento de um fenótipo senescente a partir de uma população originalmente não senescente. 
3 Objetivos 


\subsection{Objetivos Gerais}

1. Desenvolver um modelo computacional que possa ser utilizado para testar hipóteses acerca das teorias evolutivas da senescência.

2. Inferir sobre o impacto de diferentes níveis de mortalidade extrínseca na evolução da senescência.

3. Inferir sobre o impacto de diferentes níveis de mortalidade intrínseca na evolução da senescência.

\subsection{Objetivos Específicos}

1. Avaliar a hipótese de que, sob o mecanismo de acúmulo de mutações, somente genes deletérios de manifestação acima da longevidade máxima possam fixar-se em uma população (hipótese de senescência "apenas no laboratório").

2. Avaliar a hipótese alternativa de que um gene essencial com efeitos deletérios possa fixar-se em uma idade abaixo da longevidade máxima.

3. Avaliar o papel da força de seleção sobre o mecanismo de acúmulo de mutações.

4. Avaliar o papel da deriva genética aleatória sobre o mecanismo de acúmulo de mutações.

5. Descrever a dinâmica de evolução de um gene essencial com efeitos deletérios em diferentes combinações de mortalidades extrínseca e intrínseca com base nas modas das idades de manifestação selecionadas. 
4 Métodos 


\subsection{Construindo o Modelo Inicial}

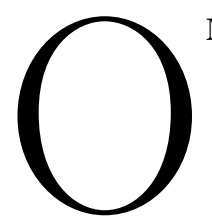

MODELO original de Medawar considerou uma população tamanho finito, constituída de $N$ indivíduos desprovidos de características de senescência (mortalidade ou fertilidade), expostos a uma mortalidade extrínseca $\mu_{e}$. Esta representa uma probabilidade fixa de morte por unidade de tempo. Em seu modelo, a ação de mutações deletérias recorrentes gera um influxo de variantes genéticas associadas a distintas idades de manifestação. As mutações cujas idades de expressão são tardias em relação à estrutura etária da população estão sujeitas a forças seletivas fracas e são, portanto, mais propensas a fixação por deriva genética.

Ressalta-se que, nesta hipótese, é a seleção diferencial sobre um influxo de alelos mutantes com distintas idades de manifestação inicial que permite o acúmulo dos mutantes deletérios cujas idades de expressão são mais avançadas, enquanto aqueles cuja idade é suficientemente jovem para serem expressas nas condições ambientais seriam eliminados. Tal conceito foi reforçado por Hamilton, ao formular matematicamente a hipótese de Medawar (Hamilton, 1966).

Para explicar a fixação de características deletérias relativamente precoces, a idéia da pleiotropia antagônica foi aventada ainda por Medawar (Seção 2.5) e desenvolvida por Williams (Seção 2.6).

O trabalho atual adota uma abordagem diferente para modelar a situação prevista por Medawar e Williams. Para avaliar suas previsões, foi construído um modelo simplificado com amostragens pelo método de Monte Carlo. Tal modelo pretendeu investigar a evolução de efeitos deletérios geneticamente codificados em uma população submetida a uma mortalidade extrínseca constante.

Como não se especificou uma arquitetura genética nos modelos originais de 
Medawar e Williams, foi utilizado um modelo constituído de uma população de tamanho fixo de $N$ indivíduos haplóides assexuados com um único locus não recombinante. Esta formulação é bastante próxima daquela descrita por Felsenstein (Felsenstein, 1971). A primeira diferença é que este modelo trata os eventos de morte independentemente e divide a mortalidade em dois componentes. O componente ambiental, chamado de mortalidade extrínseca $\left(\mu_{e}\right)$, é fixo e não evolui. Complementarmente, a mortalidade intrínseca $\left(\mu_{i}\right)$ é geneticamente determinada e fixa; porém a idade de início do efeito da $\mu_{i}$ pode mudar em resposta a forças evolutivas. A segunda diferença é que, no presente modelo, o genoma é ocupado por um gene de um tipo especial: ele produz um efeito benéfico essencial acoplado a um efeito deletério. Esta é uma adição à idéia original de Medawar e Williams.

Adicionalmente, o influxo de variantes genéticas, proposto por Medawar e Williams mas também não caracterizado em seus modelos originais (Medawar, 1952; Williams, 1957), é representado pela presença de mutações recorrentes, acontecendo com uma probabilidade $u$ por indivíduo nascido. Cada mutação introduz um novo alelo $I_{a *}$, em que a idade de manifestação inicial $a *$ de seu efeito deletério pode mudar em passos discretos de tamanho fixo $s$ e pode variar de 0 ao infinito. Uma vez atingida pelo indivíduo portador a idade de manifestação de seu gene, o efeito deletério a ele associado se torna manifesto. Todos os indivíduos possuem o mesmo alelo inicial em que $a *=0$ no início das simulações.

O locus único carrega uma cópia de um gene que produz um efeito essencial pareado a um efeito deletério, responsável pela $\mu_{i}$. Assim, em cada simulação toda a população possui este gene logo desde o início. Como este gene é essencial por definição, este não pode ser eliminado por seleção ou deriva genética. Cada alelo variante deste gene é definido pela idade $a *$ de manifestação, a qual marca o momento 
na vida de um indivíduo em que o efeito deletério genético se manifesta. Na prática, isto significa que, para $a \geq a *$, a mortalidade se torna $\mu=\mu_{e}+\mu_{i}$. Logicamente, para $a<a *$, a mortalidade $\mu=\mu_{e}$. Este é o mecanismo defendido pelo "cumulative effect model" de Charlesworth (Charlesworth, 2001). Portanto, cada genótipo define uma subpopulação $n_{a *}=n_{0}, n_{1}, \ldots, n_{A}$, cuja frequência é simplesmente $N_{a *}=\sum_{i=0}^{\infty} n_{i}$.

Como é típico nos modelos de Monte Carlo, as simulações evoluem em passos discretos de tempo (ciclos). A cada ciclo, dois processos agem sobre a população: remoção dos indivíduos mortos e reposição com indivíduos recém "nascidos", momento em que mutações sobre o genoma parental original podem ocorrer. A remoção e a reposição de indivíduos sempre ocorrem nesta ordem.

\subsubsection{Remoção e envelhecimento cronológico}

Em contraste ao modelo de Felsenstein (Felsenstein, 1971), as mortes ocorrem de forma independente. No intuito de contabilizar os dois diferentes componentes de mortalidade, para cada genótipo pode-se definir $N_{a \geq a *}=\sum_{a=a *}^{\infty} n_{a}$ e $N_{a<a *} \sum_{a=0}^{a *-1} n_{a}$. Por consequência, a frequência $N_{a} *$ de um dado genótipo é simplesmente $N_{a<a *}+N_{a \geq a *}$. Assim, o número de mortes por genótipo pode ser descrito como:

$$
\begin{gathered}
\operatorname{Binomial}\left(k_{a<a *} ; N_{a *}, \mu_{e}\right)=\left(\begin{array}{c}
N_{a *} \\
k_{a<a *}
\end{array}\right) \mu_{e}^{k_{a<a *}}\left(i-\mu_{e}\right)^{N_{a *}-k_{a<a *}} \\
\operatorname{Binomial}\left(k_{a \geq a *} ; N_{a *}-k_{a<a *}, \mu\right)=\left(\begin{array}{c}
N_{a *}-k_{a<a *} \\
k_{a \geq a *}
\end{array}\right) \mu^{k_{a \geq a *}}(i-\mu)^{N_{a *}-k_{a<a *}-k_{a \geq a *}}
\end{gathered}
$$

O modelo percorre, desta forma, todos os $K$ genótipos presentes em um dado ciclo de tempo. Ao final desta fase, a idade de cada indivíduo sobrevivente é aumentada de uma unidade. A soma de todos os indivíduos removidos por morte, 
$N_{0}=\sum_{i=0}^{K} k_{a \geq a *}+k_{a \geq a *}$, é usada na próxima fase como o número de indivíduos a serem gerados. Os indivíduos remanescentes constituem a população parental, cujos genótipos constituirão a base para os futuros nascimentos.

\subsubsection{Reposição e mutação}

Como neste modelo a fertilidade não é função nem da idade nem do genótipo dos indivíduos, para recompor uma população de tamanho original $N$, os únicos parâmetros a serem levados em conta são os números de indivíduos de cada genótipo dentro da população parental (remanescente) $N^{\prime}$. Para tanto, o modelo introduz um mecanismo de amostragem à Wright-Fisher para gerar os novos indivíduos:

$$
\operatorname{Multinomial}\left(k_{0 *}, \ldots k_{K}\right)=\left(N-N_{0}\right) ! \prod_{a *=0}^{K} \frac{p_{a *}}{k_{a *} !}
$$

onde $p_{a *}=\frac{n_{a *}}{N-N_{0}}$ e $K$ é o número atual de genótipos diferentes na população parental.

Em vez de contribuir diretamente com o genótipo parental $a *$, alguns dos recém-nascidos podem receber alelos mutados, que contribuirão com um genótipo distinto, sendo que, por definição, a idade de manifestação sempre será $\geqslant 0$. Como as mutações ocorrem independentemente nos recém-nascidos, o número de recémnascidos portadores de mutações segue a distribuição binomial

$$
\operatorname{Bin}\left(n_{a *}^{\prime \prime}, u\right)
$$

onde $n_{a *}^{\prime \prime}$ é o número de recém-nascidos oriundos do genótipo $a *$ na população parental de tamanho $N^{\prime}$.

Todos os indivíduos recém-nascidos são adicionados ao grupo do genótipo 
parental ou ao grupo do genótipo mutado com idade zero. Caso um indivíduo mutado represente um alelo novo (ou seja, para uma idade de manifestação inexistente), uma nova posição é criada para listar em grupo o novo genótipo.

Uma vez adicionados todos os indivíduos recém-nascidos aos grupos correspondentes aos seus genótipos, a população tem novamente tamanho $N$; o ciclo então, termina, podendo a simulação continuar em novos ciclos a partir de um novo processo de remoção como descrito acima.

\subsubsection{Os experimentos}

\subsubsection{Estudo preliminar}

Uma vez construído o modelo, era necessário decidir quais seriam os intervalos de valores a serem explorados nas mortalidades extrínseca e intrínseca, bem como qual tamanho utilizar para a população: se, por um extremo, uma população muito pequena pode minimizar de forma irrealista o papel da seleção natural na evolução da senescência, a ulilização de populações grandes demais mimizaria de forma irrealista o efeito da deriva genética, cuja observação é um dos objetivos do presente trabalho. Também importava saber quanto tempo / ciclos de simulação seriam necessários para observação acurada dos potenciais achados; uma última necessidade foi decidir quantas vezes repetir as simulações para cada conjunto de parâmetros para garantir a observação do comportamento médio de cada condição simulada.

Para responder estas questões, um estudo preliminar de caráter exploratório foi conduzido (não reproduzido), consistindo de simulações com as seguintes condições:

Mortalidade extrínseca (como parâmetro dos presentes modelos, chamada de $\mu_{e}$ ): dobrando a partir de $1,25 \times 10^{-2}$ até $4 \times 10^{-1}$; 
Mortalidade intrínseca (como parâmetro dos presentes modelos, chamada de $\mu_{i}$ ): também dobrando de $1,25 \times 10^{-2}$ a $4 \times 10^{-1}$;

Tamanho populacional $(N)$ : dobrando de 128 até 8192 ;

Simulações com $10^{6}$ ciclos foram conduzidos para todas as condições listadas acima; arbitrariamente, uma simuação adicional com apenas 50 repetições foi conduzida para todas as condições por $10^{7}$ ciclos, no intuito de evitar que um eventual resultado tardio não fosse detectado;

Número de repetições: realizados conjuntos de simulações com os números de repetições variando uma ordem de grandeza, de $10^{2}$ até $10^{4}$.

A partir desta exploração, chegou-se ao conjunto de parâmetros e condições que se seguem.

\subsubsection{Delineamento do estudo}

Foram realizadas simulações sob combinações distintas dos parâmetros $\mu_{e} \mathrm{e}$ $\mu_{i}$ e sob as condições abaixo descritas:

os parâmetros $\mu_{e}$ e $\mu_{i}$ receberam valores de $2,5 \times 10^{-2}$ com incremento exponencial até $2 \times 10^{-1}$; todas as combinações dos parâmetros acima foram testadas;

utilizou-se uma probabilidade de mutação da idade de manifestação do efeito deletério de $10^{-3}$ por ciclo;

o $N$ de 1024 indivíduos foi escolhido por mostrar bom desempenho computacional sem indícios de prejuízo para os fenômenos de seleção ou de deriva;

as simulações foram conduzidas por $10^{6}$ ciclos;

cada um dos conjuntos de parâmetros foi simulado com $10^{3}$ repetições. 


\subsubsection{Modelo Final: Otimizando o algoritmo}

Mutações deletérias podem influenciar na capacidade de reparo ao DNA, uma vez que os animais possuem diversos mecanismos de reparo geneticamente codificados. Mais: mutações deletérias sobre o sistema de reparo do DNA podem ser um mecanismo pelo qual a teoria do soma descartável pode funcionar. A diminuição na eficiência do reparo, que ocorre com gasto energético, pode teoricamente liberar recursos energéticos para reprodução. O resultado disto é que as taxas de mutação podem, elas próprias, ser um parâmetro sujeito à evolução.

Embora tivéssemos o intuito de simplificar o modelo ao colocar o efeito do gene deletério diretamente sob uma probabilidade de mutação, sabemos que não é o que acontece; não só o fenótipo não é a unidade sob mutação: tampouco o gene o é: mutações ocorrem nos pares de base do DNA; mesmo um único gene possui centenas ou milhares de pares de bases, cada um deles sujeito a mutações. De acordo com a teoria neutra, portanto, o número de substituições de aminoácidos em uma determinada proteína, resultante de mutações sobre o DNA, apresenta uma distribuição Poisson (Maynard Smith, 1997, pág. 150).

Para podermos estudar a influência de distintas taxas de mutação no modelo, e adequá-lo a uma arquitetura genética mais realista, um novo modelo foi criado através da modificação do mecanismo de mutações. O mecanismo de mutações descrito para o modelo anterior pela Equação 4.4, não é mais utilizado.

Assim, o modelo final é idêntico ao modelo anterior, mas alguns dos indivíduos novos, gerados da forma descrita na Seção 4.1.0.2 pela Equação 4.3, agora podem sofrer $m$ mutações sorteadas a partir de uma distribuição Poisson 


$$
P(m ; \lambda)=\frac{\lambda^{m} e^{-\lambda}}{m !}
$$

onde $\lambda$ é a taxa de mutação. Cada mutação soma uma unidade de tempo escolhida aleatoriamente entre $s=+1,-1$ à idade original de manifestação do alelo mutado. Múltiplas mutações têm seus efeitos somados. Este esquema de passeio aleatório é compatível com o modelo de sítios infinitos, em que se concebe um efeito aleatório para cada mutação. Desta forma, uma reversão ao fenótipo original é possível, mesmo sem a ocorrência de uma mutação reversa.

Uma vez que as teorias evolutivas da senescência se apóiam na estruturação etária das populações, o conceito de tamanho populacional efetivo $\left(N_{e}\right)$ é um componente importante para o entendimento destas teorias. Por isto, no Modelo Final passamos a medir os parâmetros necessários para seu cálculo. Para o nosso modelo, o $N_{e}$ global em um determinado ciclo de simulação pode ser expresso como

$$
N_{e}=\frac{N_{0} T}{1+\frac{N_{0}}{N} \sum_{a}^{\infty} \frac{q_{a+1}^{2} a+1}{1-\frac{N_{0}}{N}}}
$$

onde

$q_{a}=\sum_{i=a}^{\infty} \frac{n_{i}}{N}$,

$T=\sum_{a=0}^{\infty} \frac{n_{a}}{N}=$ média etária do indivíduo reprodutor,

$N=$ tamanho populacional absoluto e

$N_{0}=$ tamanho populacional absoluto inicial.

Note-se na Equação 4.6 que a razão $\frac{N_{0}}{N}$ representa a mortalidade medida em um ciclo, mantendo o registro ciclo a ciclo das flutuações percebidas. A presente Equação 4.6 é apenas uma transcrição da fórmula para o cálculo de $N_{e}$ em populações com sobreposição de gerações e variações em mortalidade e natalidade, descrita por Felsenstein (Equação B.15), utilizando-se os parâmetros da forma como são 
mensuráveis em nosso modelo. É intuitivo perceber que menores probabilidades de morte, $\mu$, implicam em maiores valores de $N_{e}$, uma vez que resultam em menor oscilação da população. Esta fórmula também foi utilizada por levar em conta a contribuição de cada grupo etário ao $N_{e}$.

\subsubsection{Experimentos}

Para estudarmos os efeitos de distintos níveis de mortalidades extrínseca $\left(\mu_{e}\right)$ e intrínseca $\left(\mu_{i}\right)$, foram conduzidas simulações com cada uma das combinações de parâmetros mencionadas na Tabela 4.1.

\begin{tabular}{ccc}
\hline$\mu_{e}$ & $\mu_{i}$ & Comentário \\
\hline $10^{-2}$ & 0 & Caso neutro \\
$10^{-1}$ & 0 & Caso neutro \\
$10^{-2}$ & $10^{-2}$ & $\mu_{e}=\mu_{1}$ \\
$10^{-1}$ & $10^{-1}$ & $\mu_{e}=\mu_{1}$ \\
$10^{-1}$ & $10^{-2}$ & $\mu_{e} \gg \mu_{1}$ \\
$10^{-2}$ & $10^{-1}$ & $\mu_{e} \ll \mu_{1}$ \\
\hline
\end{tabular}

Tabela 4.1 - Modelo Final. Condições simuladas. Para cada uma das condições acima, taxas de mutação $\lambda$ foram empregadas com os valores de $10,1,10^{-1}, 10^{-2} \mathrm{e}$ $10^{-3}$.

Cada uma das 30 combinações de parâmetros foi executada com população de $10^{3}$ indivíduos, durante $10^{5}$ ciclos. Foram realizadas $10^{3}$ repetições de cada simulação. Para cada uma destas, coletou-se, ciclo a ciclo, em planilha

A média das idades de manifestação dos alelos sob evolução (MIMED);

O valor do tamanho populacional efetivo $\left(N_{e}\right)$;

O número de alelos simultaneamente presentes em cada ciclo. 
A observação direta ciclo a ciclo da evolução das distribuições dos alelos para todas idades de manifestação existentes em cada ciclo geraria de difícil manipulação. Por esta razão, foram obtidas para cada simulação as curvas de sobrevida das populações nos tempos inicial $\left(t_{0}\right)$ e em um tempo fixo $t_{f}=10^{5}$ ciclos. Adicionalmente foram registradas as distribuições dos alelos (DA) presentes em $t_{f}$ pelas idades de manifestação. Os resultados foram analisados com o auxílio do ambiente estatístico $R$. 
5 Resultados 


\subsection{Modelo Inicial}

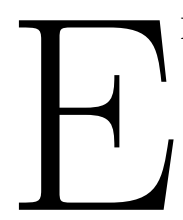

M todas as condições simuladas, as médias das idades de manifestação dos alelos deletérios (MIMED) se deslocaram progressivamente para valores

mais altos ao longo do tempo, como se vê na. Este aumento inicialmente mais rápido das MIMED foi seguido por uma desaceleração, dando lugar a longos perídos de subida lenta. Esta situação foi mais marcada nas simulações simultaneamente sob os maiores valores de $\mu_{e}$ e $\mu_{i}$ (por exemplo, na Figura 5.4).Todos os resultados são as médias para as $10^{3}$ repetições.

\subsubsection{A mortalidade caiu ao longo do processo}

A mortalidade das populações $(\mu)$ caiu ao longo de todas as simulações. A Figura 5.2 mostra o comportamento típico desta queda: ao longo das simulações, $\mu$ inicia equivalendo à soma $\mu_{e}+\mu_{i}$, mas tende para o valor unicamente de $\mu_{e}$. A queda é rápida de início, mas se lentifica à medida em que $\mu$ se aproxima do valor de $\mu_{e}$.

\subsubsection{Efeito da mortalidade extrínseca}

Ambientes com maiores mortalidades extrínsecas $\left(\mu_{e}\right)$ estiveram ligados às menores MIMED em $t_{f}$, para todas as simulações (Figura 5.4). No entanto, para cada nível de $\mu_{i}$, maiores níveis de $\mu_{e}$ também se relacionaram a uma ascensão inicialmente mais rápida das MIMED. 


\subsubsection{Efeito da mortalidade intrínseca}

Simulações envolvendo maiores mortalidades intrínsecas $\left(\mu_{i}\right)$ evoluíram mais rapidamente. Além disto, simulações sob os maiores valores de $\mu_{i}$ (sob uma mesma $\mu_{e}$ ) evoluíram para MIMEDs mais tardias em um mesmo tempo de simulação (compare as distribuições sob distintos parâmetros na Figura 5.1).

\subsubsection{O efeito combinado das mortalidades}

A Figura 5.1 mostra os efeitos combinados de $\mu_{e}$ e $\mu_{i}$. Nos casos mais extremos, pode-se notar alongamento da curva de sobrevida, com mais grupos etários representados na população. As estruturas etárias, no entanto, evoluem de forma distinta em relação à mortalidade subjacente: populações submetidas às menores $\mu_{e}$ (linhas superiores) alteraram suas estruturas etárias mais do que populações sob as mais altas $\mu_{e}$ (última linha). Os valores de $\mu_{i}$, no entanto, parecem exercer um efeito inverso: neste conjunto, as populações sob os maiores níveis de $\mu_{i}$ (coluna da direita) sofreram maiores alterações em sua estrutura etária do que aquelas com os menores níveis de $\mu_{i}$ (coluna da esquerda). Quando $\mu_{e}$ e $\mu_{i}$ se mostraram em seus extremos opostos de intensidade, o efeito conjunto maximizou a transição demográfica (canto superior direito) ou minimizou este efeito (canto inferior esquerdo). Compare algumas destas estruturas etárias com as correspondentes trajetórias da mortalidade, nas Figuras 5.2 e 5.3.

\subsection{Modelo Final}

Também no modelo final as MIMED evoluíram para idades mais avançadas em todas as condições simuladas. De modo geral, simulações sob as mais altas taxas 
de mutação $(\boldsymbol{\lambda})$ resultaram em valores mais altos para as MIMED durante todo o tempo de simulação (Figura 5.6).

\subsubsection{Mudanças na estrutura etária}

As populações portadoras de genes neutros (i.e., cujo parâmetro $\mu_{i}$ é igual a zero) mantiveram em $t_{f}$ as mesmas distribuições que apresentavam originalmente (Figuras 5.7A e 5.7B). Em contraste, as outras populações assumiram no $t_{f}$ estruturas etárias mais longevas do que apresentavam originalmente (Figuras 5.7C a 5.7F). Estas últimas, no entanto, apresentaram dois padrões de estrutura etária distintos entre si. As estruturas etárias em $t_{f}$ nas Figuras 5.7C e 5.7E apresentaram nítidas inflexões em suas inclinações em um certos momentos entre $t_{0}$ e $t_{f}$. Diferentemente, as distribuições representadas nas Figuras 5.7D e 5.7F parecem ser constituídas por inclinações únicas.

\subsubsection{Evolução das distribuições de alelos por idade de ma- nifestação}

As distribuições dos alelos (DA) em função das idades de manifestação também evoluíram para idades mais avançadas em $t_{0}$. Nos casos neutros, isto se deu sem que as modas de DA se desconectassem da idade original zero (Figuras 5.7A e 5.7B).

Nos casos não neutros, as modas das DA se estabeleceram em idades mais avançadas ao tempo $t_{f}$ (Figuras $5.7 \mathrm{C}$ a $5.7 \mathrm{~F}$ ). Novamente estes últimos conjuntos de simulações mostraram dois padrões distintos. Nas Figuras 5.7C e 5.7E, as modas das DA parecem coincidir com as inflexões das distribuições etárias das populações correspondentes (mesma cor). A partir deste ponto, estas inflexões colocam as inclinações em paralelo à inclinação original, representada em azul claro. Nas 
Figuras 5.7D e 5.7F, em que não se constatou a presença de inflexões, as modas das DA coincidem aproximadamente com o término das distribuições etárias.

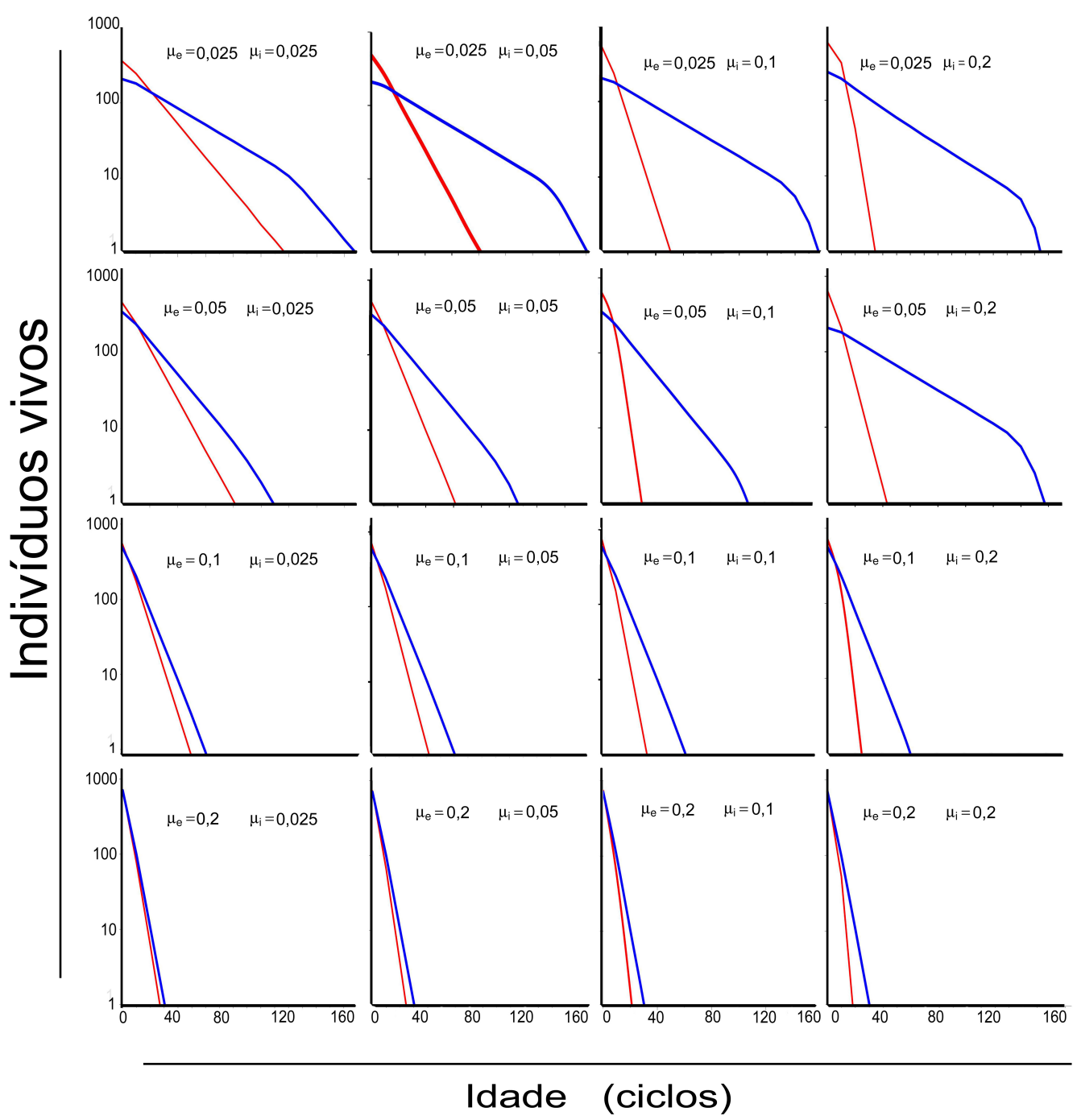

Figura 5.1 - Modelo Inicial. Curvas de sobrevida das 16 simulações realizadas. O número de sobreviventes é representado em escala logarítmica, ao passo que as idades sao mostradas em escala linear. Estão representadas as médias da composição etária de cada população durante os primeiros $10^{3}$ ciclos da simulação (em vermelho) e durante os últimos $10^{3}$ ciclos (em azul). Houve transição demográfica em todos os casos, com aumento da longevidade da população (queda no número de jovens, à esquerda e aumento do número de mais idosos. 


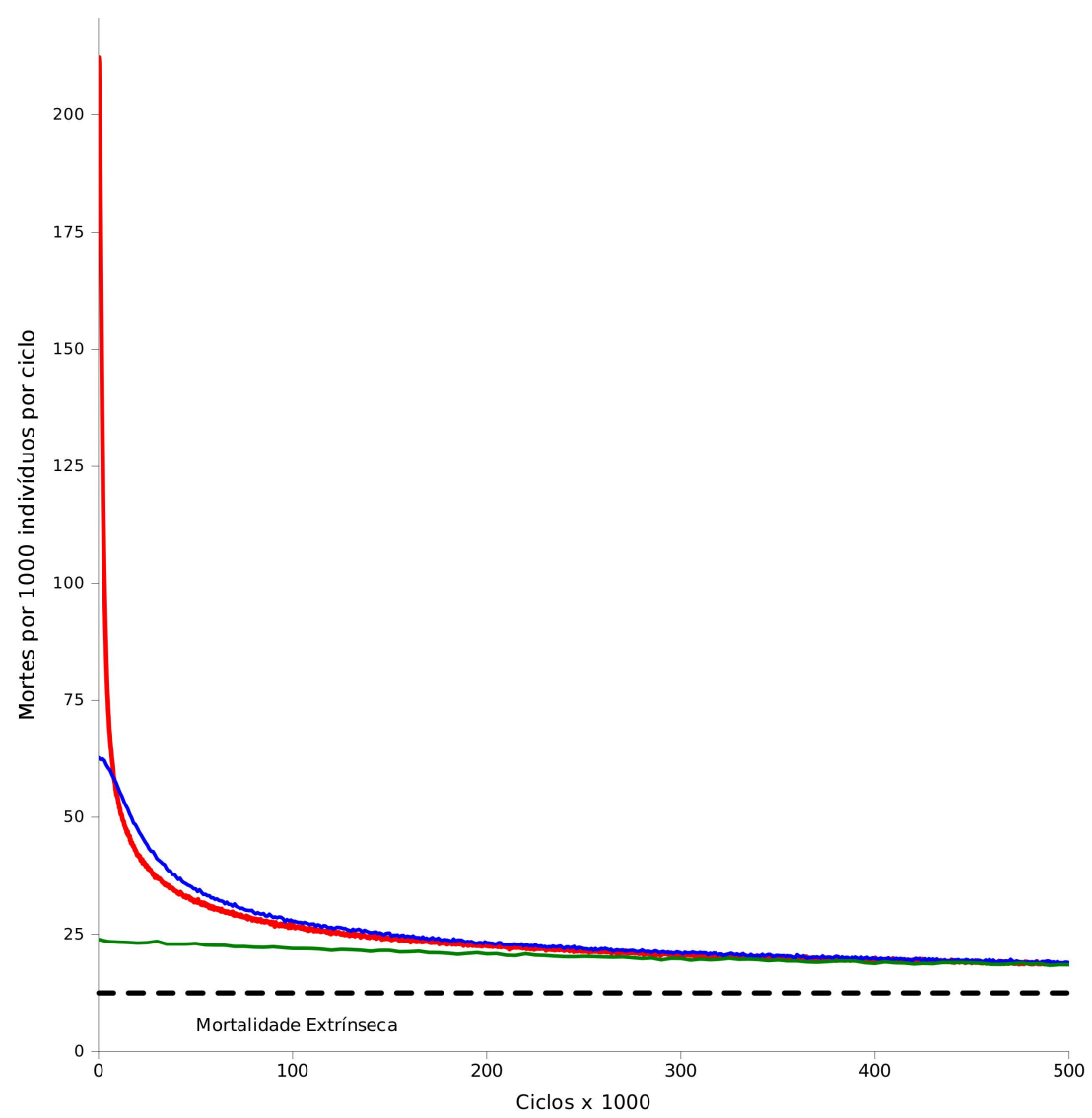

Figura 5.2 - Modelo Inicial. Variação da mortalidade total $(\mu)$ por ciclo em três populações submetidas à mesma probabilidade extrínseca de morte $\mu_{e}=0,0125$ por ciclo. Os valores das probabilidades de morte associadas à $\mu_{i}$ diferem nas três curvas. Linha verde: $\mu_{i}=0,0125$ por ciclo; linha azul: $\mu_{i}=0,05$ por ciclo; linha vermelha: $\mu_{i}=0,2$ por ciclo. As três linhas representam as taxas de mortalidade por 1000 indivíduos, medidas ao longo de cada simulação e relacionadas à probabilidade total de morte $\mu$. O eixo-X pontilhado enfatiza a $\mu_{e}$, fixas nas simulações. A mortalidade total caiu à medida que tanto a estrutura etária quanto os valores das MIMED mudavam. Note que a mortalidade inicial é compatível com a mortalidade esperada em 1000 indivíduos sob uma probabilidade de de morte $\mu=\mu_{e}+\mu+i$, porém cai rapidamente em direção ao limite mínimo $\left(\mu_{e}\right)$.

\subsubsection{Variações no tamanho populacional efetivo $\left(N_{e}\right)$}

Neste grupo de simulações, $N_{e}$ foi calculado ciclo a ciclo. Em todas as simulações $N_{e}$ partiu de um tamanho menor do que o tamanho de $N$, mantendo-se estável durante o início das simulações. Após isto, $N_{e}$ apresentou uma rápida inflexão, caindo em todas as simulações até um valor mínimo, a partir do qual imediatamente 


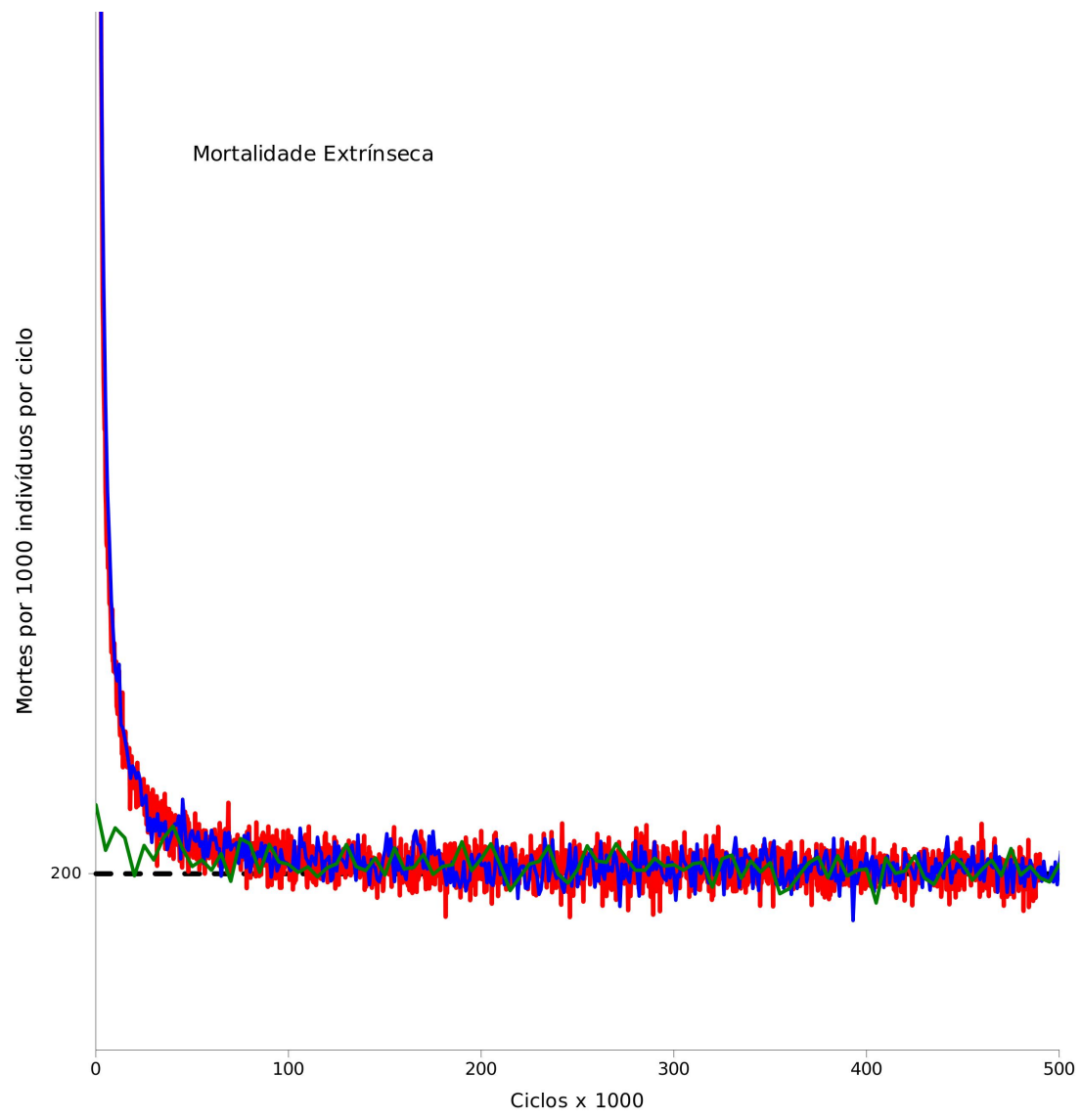

Figura 5.3 - Modelo Inicial. Variação da mortalidade total $(\mu)$ por ciclo em três populações submetidas à mesma probabilidade extrínseca de morte $\mu_{e}=0,2$ por ciclo. Os valores das probabilidades de morte associadas à $\mu_{i}$ diferem nas três curvas. Linha verde: $\mu_{i}=0,0125$ por ciclo; linha azul: $\mu_{i}=0,05$ por ciclo; linha vermelha: $\mu_{i}=0,2$ por ciclo. As três linhas representam as taxas de mortalidade por 1000 indivíduos, medidas ao longo de cada simulação e relacionadas à probabilidade total de morte $\mu$. O eixo-X pontilhado enfatiza a $\mu_{e}$, fixas nas simulações. A mortalidade total caiu à medida que tanto a estrutura etária quanto os valores das MIMED mudavam. Note que a mortalidade inicial é compatível com a mortalidade esperada em 1000 indivíduos sob uma probabilidade de de morte $\mu=\mu_{e}+\mu+i$, porém cai rapidamente em direção ao limite mínimo $\left(\mu_{e}\right)$. Compare com a Figura refmortality, em que a maior queda, dada pela combinação de uma $\mu_{e}$ baixa e uma $\mu_{i}$ alta é muito mais pronunciado do que o observável neste conjunto de parâmetros.

voltou a subir, ultrapassando os valores iniciais e estabilizando-se em um valor entre o valor iniciamente mantido e o valor real $N$. Este conjunto de fenômenos não é completamente visualizado em todas as curva de $N_{e}$. 


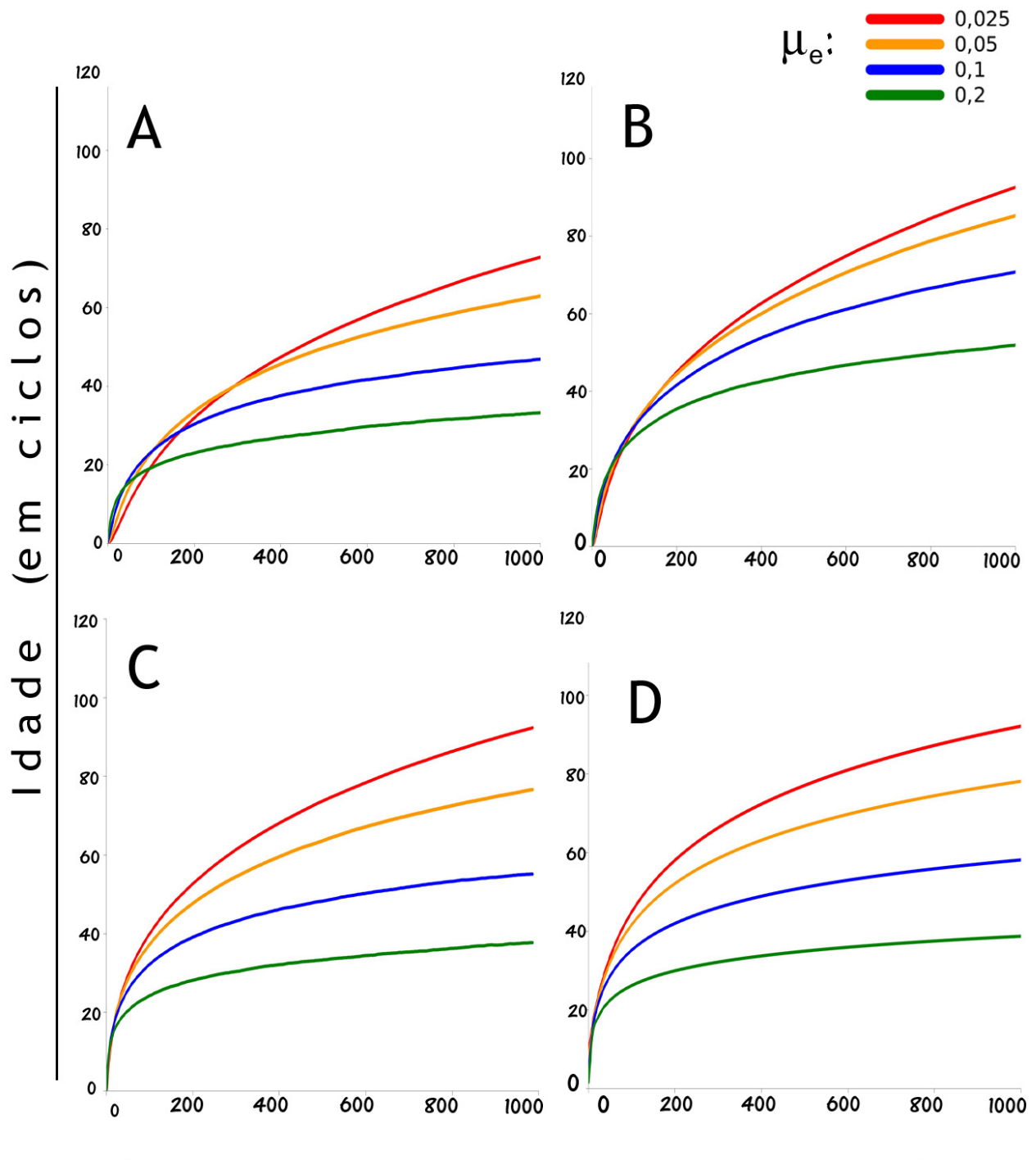

Tempo de simulação (em ciclos $x$ 1000)

Figura 5.4 - Modelo Inicial. Evolução das MIMED de um alelo para $\mu_{i}=0,1$ por ciclo em simulações com diferentes níveis de $\mu_{e}$, variando de 0,025 a 0,2 por ciclo; população 1024. Comparada com a Figura 5.4, os valores das MIMED são mais altos para um mesmo número de ciclos e parecem tender a níveis mais altos do que os observados sob menores valores de $\mu_{i}$.

\subsubsection{Os efeitos combinados da mortalidade e da mutação}

Nos casos em que o influxo de mutações $N \mu \lambda \gg 1$, as populações sob seleção apresentaram uma evolução de $D A$ e da distribuição etária muito semelhante ao caso neutro, com curvas lisas. No entanto, algumas diferenças puderam ser notadas nas 


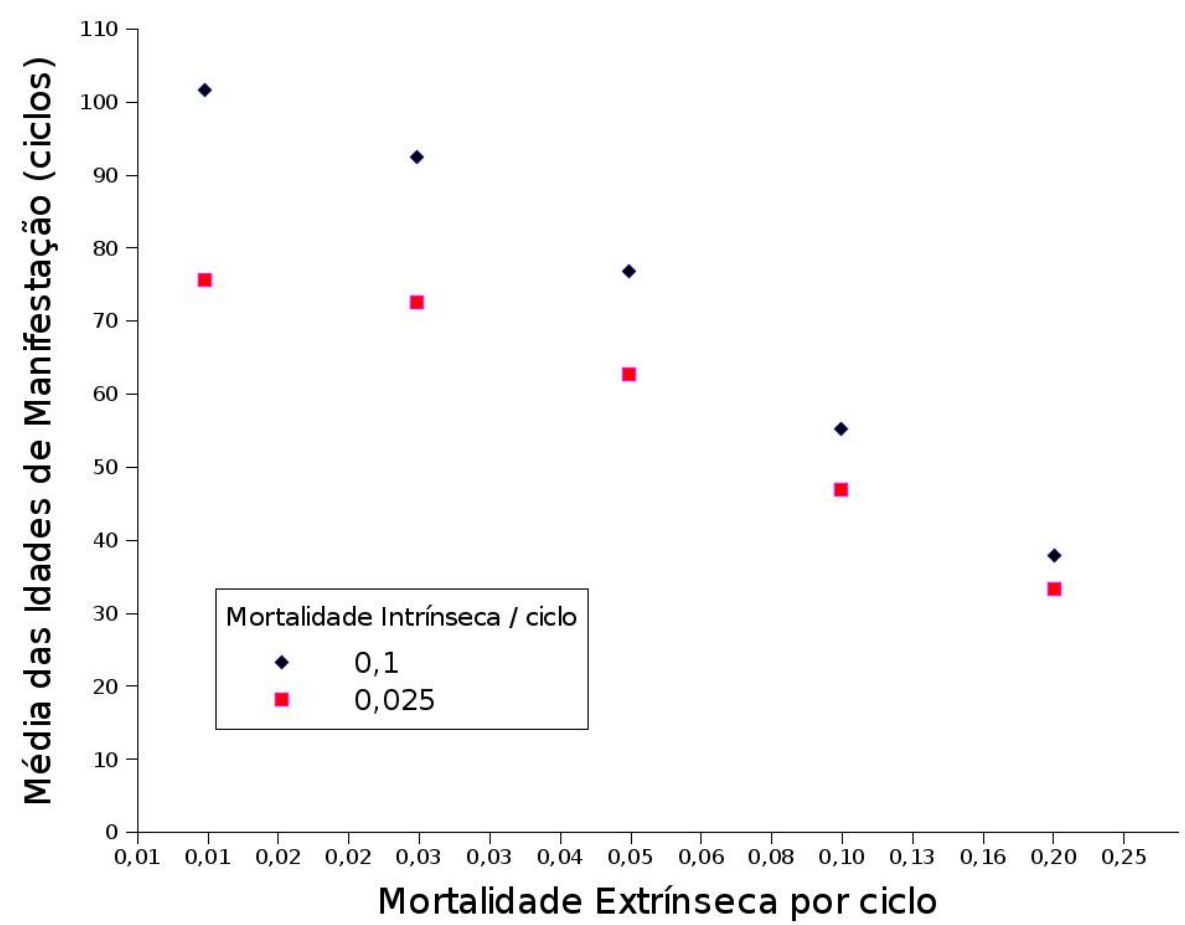

Figura 5.5 - Modelo Inicial. Valores de MIMED atingidos em $10^{6}$ ciclos em função de $\mu_{e} . \mu_{i}=0,1$ por ciclo (losangos azuis) e $\mu_{i}=0,025$ por ciclo (quadrados vermelhos); população 1024. Maiores níveis de $\mu_{i}$ parecem estar relacionados à seleção de maiores idades de manifestação para uma mesma mortalidade extrínseca $\left(\mu_{e}\right)$.

distribuições etárias e dos alelos. A diferença de inclinação na distribuição etária em $t_{0}$ e $t_{f}$ é compatível com a evolução de $\mu=\mu_{e}+\mu_{i}$ para $\mu=\mu_{e}$, como esperado (Figura 5.7). De fato, considerando-se todas as distribuições etárias, torna-se claro que a inclinação apresentada nas distribuições etárias em $t_{f}$ após a moda de $A$ é sempre igual à inclinação inicial $\left(t_{0}\right)$ para as mesmas condições. Isto significa que após este ponto a estrutura etária da população ainda é determinada pela condição inicial $\mu=\mu_{e}+\mu_{i}$.

Em outros exemplos, como nos casos neutros, (Figura 5.7), em que $\mu_{i}=0 \mathrm{ou}$ $\mu_{e}=10^{-1}$ e $\mu_{i}=10^{-2}$, (Figuras 5.6 e 5.9), a seleção se mostrou incapaz de eliminar completamente os alelos com início precoce do efeito deletério e a distribuição das idades de manifestação se manteve conectada com a idade original 0. Em geral, 
combinações semelhantes dos parâmetros mostraram resultado semelhantes ao caso mostrado na Figura 5.7, como $\mu_{e}=10^{-1}$ e $\mu_{i}=10^{-2}$ (não mostrados).

\subsubsection{O Efeito da Mortalidade Extrínseca}

Populações sob os maiores níveis de $\mu_{e}$ apresentaram as estruturas etárias mais jovens observadas no tempo $t_{f}$. Isto é visualizável na Figura 5.7, nos painéis à painéis à direita: a distribuição etária final é sempre menos longeva à direita do que imediatamente à esquerda. Os painéis à direira representam populações cuja $\mu_{e}$ é de $10^{-1}$ por ciclo, ao passo que $\mu_{e}$ vale $10^{-2}$ por ciclo em toda a coluna à esquerda da Figura 5.7.

\subsubsection{O Efeito da Mortalidade Intrínseca}

Foram testadas três situações específicas, com base na proporcionalidade $\frac{\mu_{i}}{\mu_{e}}$ : $\mu_{i}$ significativamente inferior, igual ou significativamente superior à $\mu_{e}$

O efeito da magnitude relativa de $\mu_{i}$ pode ser observado na Figura 5.7, considerando-se sequencialmente as quatro situações:

1. $\mu_{e}=10^{-1} / \mu_{i}=0$ (i.e., um caso neutro),

2. $\mu_{e}=10^{-1} / \mu_{i}=10^{-2}$ (i.e., $\mu_{i} \ll \mu_{e}$ ),

3. $\mu_{e}=10^{-1} / \mu_{i}=10^{-1}$ ou $\mu_{e}=10^{-2} / \mu_{i}=10^{-2}$ (i.e., $\mu_{i}=\mu_{e}$ ),

4. $\mu_{e}=10^{-2} / \mu_{i}=10^{-1}$ (i.e., $\mu_{i} \gg \mu_{e}$ ).

No caso neutro (1), a distribuição dos alelos tem a moda na idade 0 , sem nenhuma modificação observável na estrutura etária da população ao longo da evolução. 
No segundo caso $\left(\mu_{i} \ll \mu_{e}\right)$, a moda da distribuição de alelos ocorreu por volta da idade 100 mas a curva de distribuição se manteve assimétrica, com muitos portadores do alelo para idade de manifestação 0 ainda presentes. a moda da distribuição de alelos.

No terceiro caso $\left(\mu_{i}=\mu_{e}\right)$, a alteração na moda da distribuição dos alelos foi ainda mais pronunciada, uma vez que em simulações com taxas de mutação idênticas, a moda da distribuição dos alelos é superior àquelas do segundo caso, além de que a distribuição dos alelos já se desconectou completamente da idade 0 em ambos os casos (compare-se as distribuições dos alelos nos painéis C e F da Figura 5.7, com as distribuições de alelos em D (em que $\left.\mu_{i} \ll \mu_{e}\right)$.

No quarto caso, em que $\mu_{i} \gg \mu_{e}$, a transição nas modas de idade de manifestação foi a mais acentuada de todas as situações, como pode ser visualizado no painéis inferiores da Figura 5.7. 
(A) $\mu_{\mathrm{e}}=10^{-2} \quad \mu_{\mathrm{i}}=0$

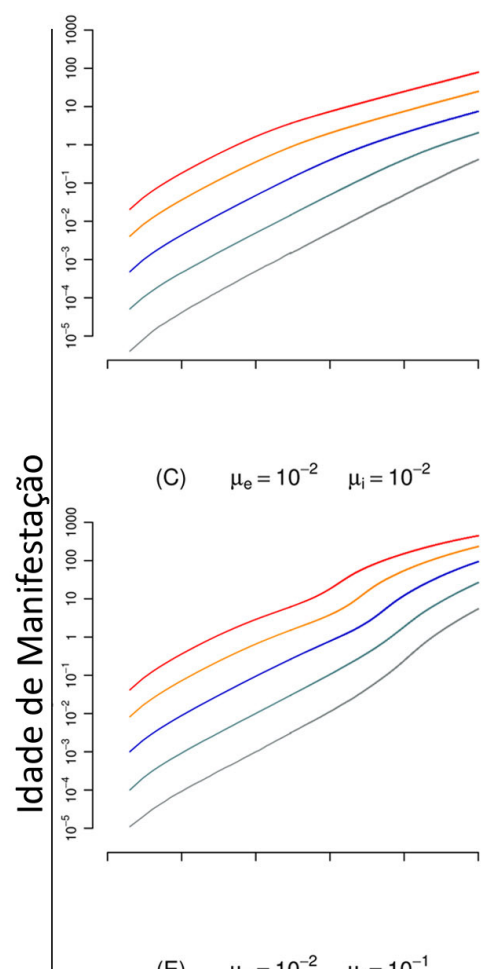

(E) $\quad \mu_{e}=10^{-2} \quad \mu_{i}=10^{-1}$

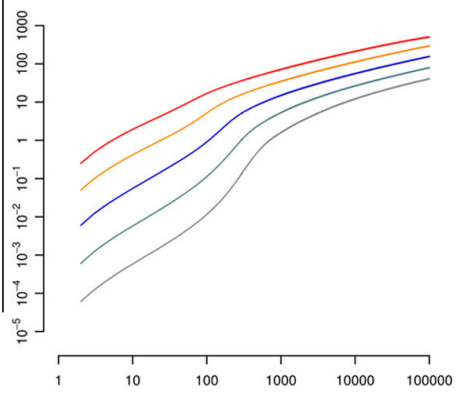

(B) $\quad \mu_{e}=10^{-1} \quad \mu_{i}=0$

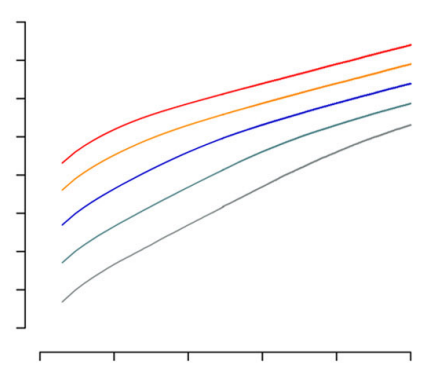

(D) $\mu_{\mathrm{e}}=10^{-1} \quad \mu_{\mathrm{i}}=10^{-2}$

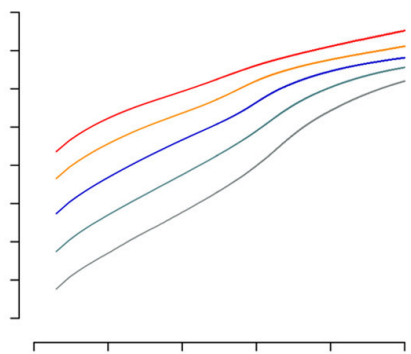

(F) $\quad \mu_{e}=10^{-1} \quad \mu_{i}=10^{-1}$

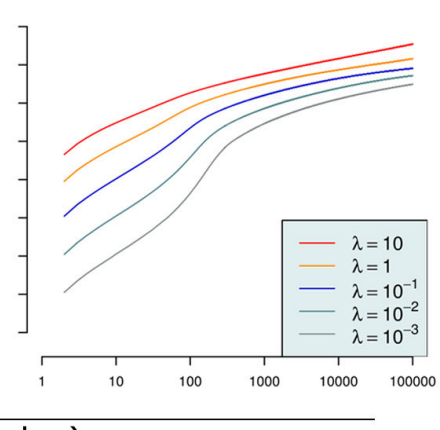

Figura 5.6 - Curva de evolução das MIMED ao longo da evolução para diferentes combinações de $\mu_{e}$ e $\mu_{i}$, expressas como probabilidade de morta por ciclo. Modelo Final. $10^{6}$ ciclos. As escalas de tempo e idades de manifestação são ambas logarítmicas. As combinações de $\mu_{e}$ e $\mu_{i}$ nos diferentes painéis é a mesma utilizada na Figura 5.7. Embora os valores atingidos pelas MIMED no tempo $t_{f}=10^{6}$ ciclos tenha sido aproximadamente iguais, mantidas as taxas de mutação correspondentes (identificadas por curvas com a mesma cor e variando de $\lambda=10$ até $\lambda=10^{-3}$ ), as situações em que $\mu_{i}$ foi maior (painéis inferiores) foram correlacionadas com uma maior aceleração inicial das MIMED no sentido de maiores valores. Este fenômeno é mais facilmente visível nas curvas obtidas com as menores taxas de mutação. De um modo geral, taxas de mutação mais altas estiveram correlacionadas com maiores idades de manifestação ao longo da evolução. 


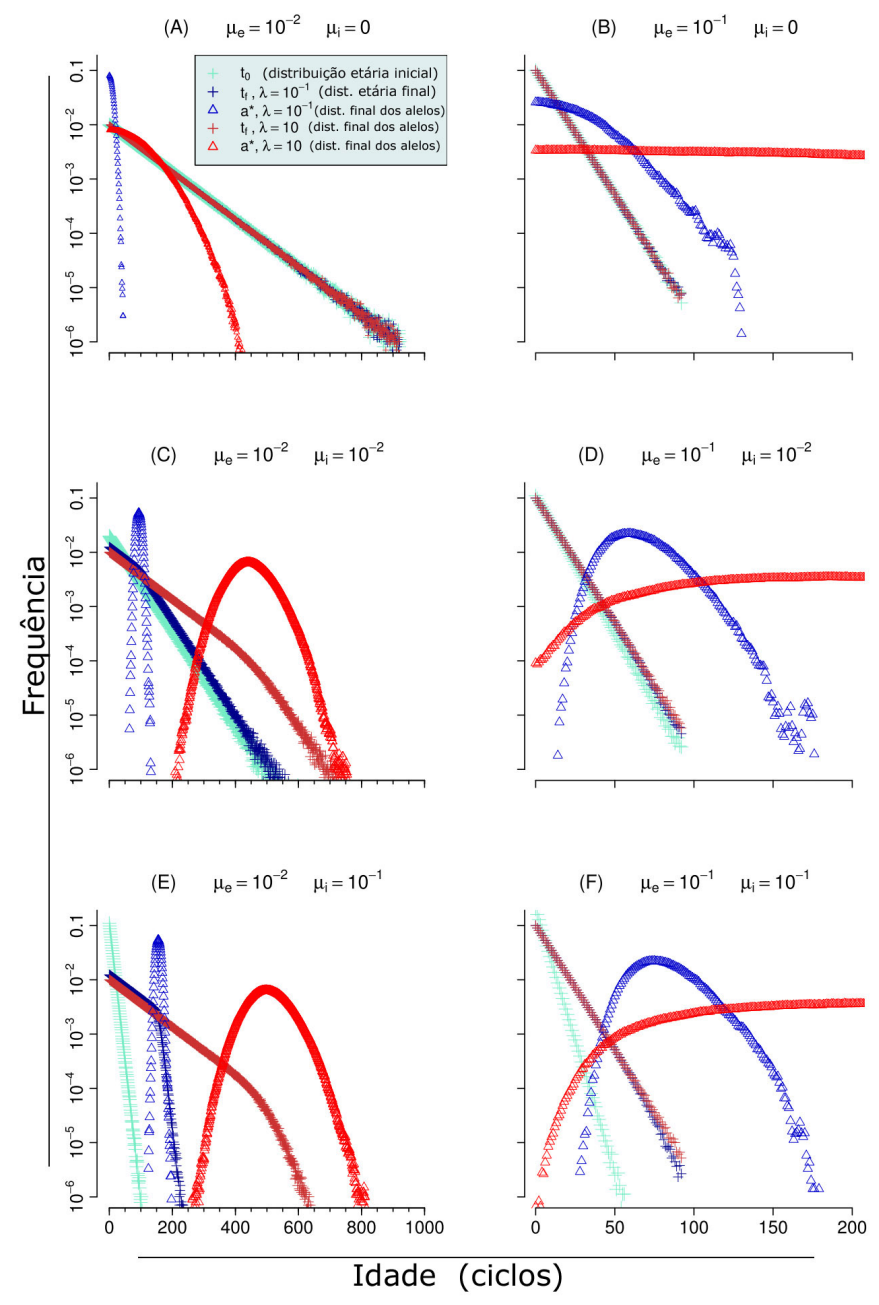

Figura 5.7 - Modelo Final. Distribuições típicas dos grupos etários e das idades de manifestação dos genes deletérios, para distintas combinações de $\mu_{e}$ a $\mu_{i}$, expressas como probabilidades de morte por ciclo. A escala de idade é linear e a de frequência, logarítmico. Cada painel apresenta cinco curvas: a distribuição etária da população no início $t_{0}$ (azul claro), as distribuições finais $\left(t_{f}\right)$ sob taxa de mutaçãp $\lambda=10^{-1}$ (azul escuro) e $\lambda=10$ (vermelho) e as suas respectivas distribuições finais dos alelos (DA) por idade de manifestação $(a *)$, mostradas também em azul $\left(\lambda=10^{-1}\right)$ e vermelho $(\lambda=10)$. Os painéis $\mathrm{A}$ e B ilustram casos neutros (i.e., $\mu=0$ ). Nestes, a distribuição etária das populações não mudou de $t_{0}$ a $t_{f}$, além de haverem persistido genes com idade de manifestação igual a zero nas populações ilustradas, ainda que com maior variação cmo aumento de $\lambda$. Os painéis centrais e inferiores ilustram três casos em que $\mu_{i}<<\mu_{e}(\mathrm{D}), \mu_{i}=\mu_{e}\left(\mathrm{C}\right.$ e F), e $\mu_{i}>>\mu_{e}(\mathrm{E})$. 


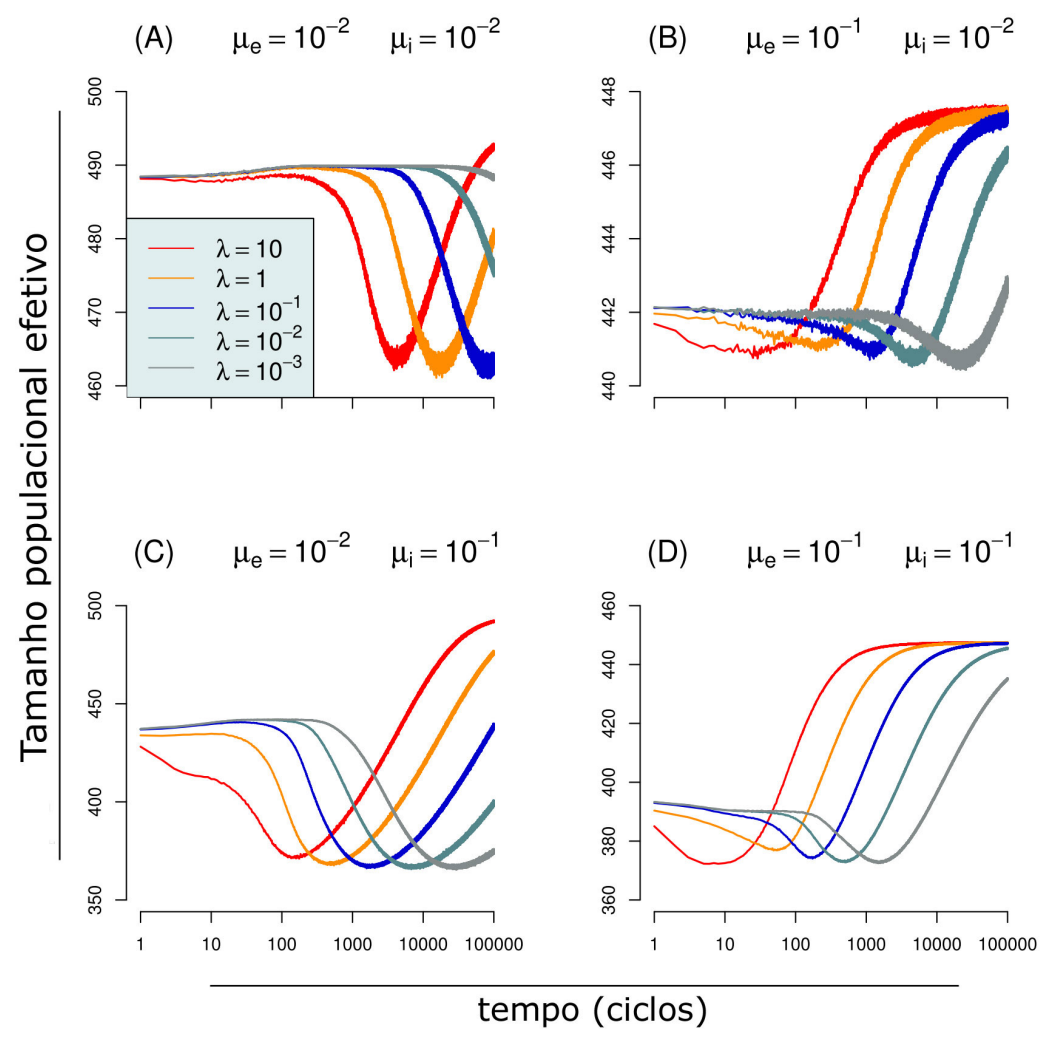

Figura 5.8 - Tamanho populacional efetivo $\left(N_{e}\right)$ ao longo de $10^{5}$ ciclos, Modelo Final. A escala de $N_{e}$ é linear, ao passo que a escala de tempo (ciclos) é logarítmica. Painéis individuais representam cenários com diferentes combinações de $\mu_{e}$ e $\mu_{i}$, expressas como probabilidades de morte por ciclo. Dentro de cada painel, cada curva representa diferentes taxas de mutação $(\lambda)$ variando de 10 a $10^{-3}$ por ciclo. Em todas as curvas, $N_{e}$ parece apresentar um período de estabilidade, para então cair até um valor mínimo e finalmente subir até um valor final máximo, o qual parece depender dos valores das mortalidades, mas não das taxas de mutação. Taxas de mutação mais altas, por sua vez, tenderam a acelerar o processo evolucionário que uma determinada combinação de $\mu_{e}$ e $\mu_{i}$ produziria (compare entre as curvas dentro de um mesmo painel). Maiores mortalidades iniciais $\left(\mu_{e}+\mu_{i}\right)$ também se correlacionaram com maior velocidade de evolução dos fenômenos descritos. 


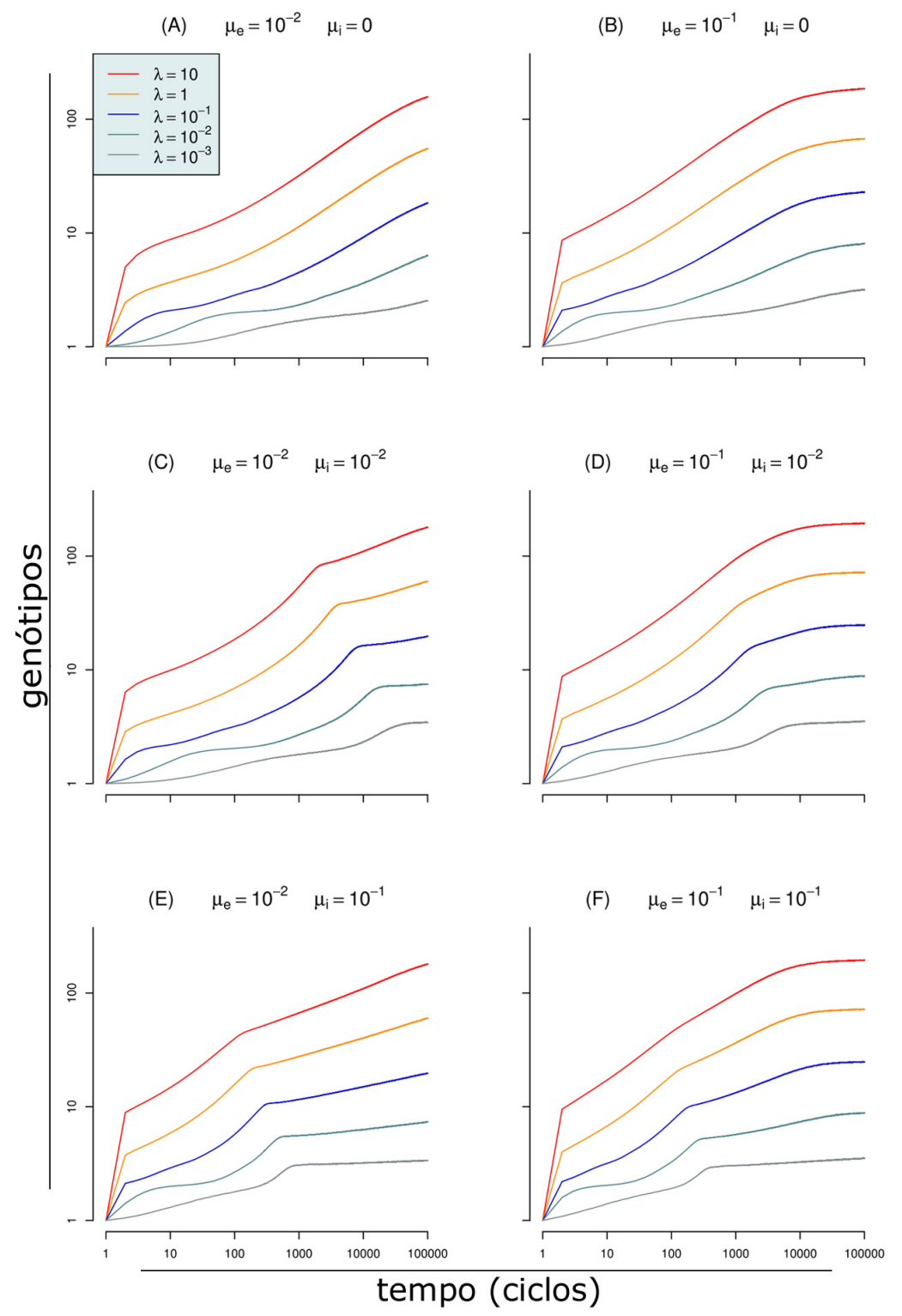

Figura 5.9 - Número de genótipos ao longo da evolução. Modelo final. $10^{5}$ ciclos. As escalas de genótipos e tempo (ciclos) são logarítmicas. As combinações de $\mu_{e}$ e $\mu_{i}$ nos diferentes painéis são as mesmas em relação às posições correspondentes nas Figuras 5.7 e 5.6. O número de genótipos sobe rapidamente e tende a valores mais altos nas taxas de mutação mais altas. Simulações com maiores taxas de mutação tendem a apresentar uma primeira inflexão súbita e a seguir aumentam em menores velocidades. À exceção dos casos neutros, muitas curvas apresentam uma segunda inflexão por volta dos últimos ciclos simulados, após a qual a velocidade de aumento no número de genótipos cai ainda mais: estes são os casos em que os alelos iniciais, com idade de manifestação $=0$, foram completamente eliminados. Compare as distribuições etárias na Figura 5.7 com o número de genótipos para as mesmas combinações $\mu_{e}$ e $\mu_{i}$ e $\lambda$ na presente Figura. 
6 Discussão 


\subsection{Modelo Inicial}

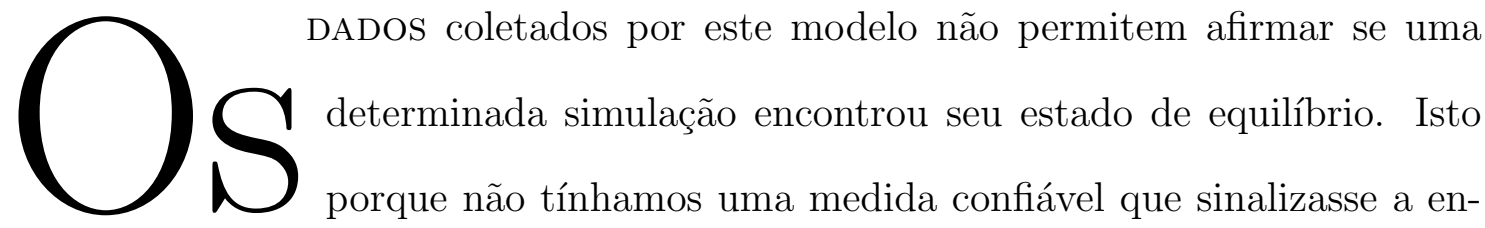
trada do modelo no estado estacionário. Ressalte-se que o alelo em si é má medida, pois tanto sob seleção muito fraca quanto por deriva ele poderá continuar a aumentar no estado de equilíbrio.

De fato, espera-se que por deriva genética a idade do alelo continue a subir. De acordo com o modelo de alelos infinitos, mesmo nas condições de equilíbrio efetivo com o processo de seleção, as idades de manifestação dos alelos existentes na população deverão estar distribuídos em torno do valor da MIMED. Assim, mutações para idades de manifestação mais precoces a partir de alelos com idades de manifestação no limite inferior desta distribuição sofrerão oposição, ainda que fraca, do mecanismo de seleção, enquanto mutações para idades de mais tardias a partir de alelos com idades de manifestação no limite superior da distribuição não sofrem nenhuma ação da seleção. Por esta razão, no estado de equilíbrio, a média das idades de manifestação tende a continuar aumentando por deriva.

\subsection{O Modelo Final}

O modelo final permitiu que estudássemos os efeitos de diferentes taxas de mutação sobre a dinâmica evolutiva da senescência. Incorporamos no modelo os dados necessários para medir a cada ciclo o tamanho populacional efetivo $\left(N_{e}\right)$, o que tornaria possível a medida indireta da força de seleção ao longo das simulações. 


\subsubsection{Evolução de uma característica deletéria em um locus essencial}

Podemos verificar nas Figuras 5.6A e 5.6B (em que $\mu_{i}$ é igual a zero) que a MIMED evolui para idades mais avançadas mesmo sob genes cujas variantes eram neutras.

No entanto, em um modelo incluindo os pressupostos necessários para a evolução da senescência, ou seja, a existência de uma probabilidade extrínseca de morte, (ME, que é ambientalmente determinada e independente de idade) e de fenótipos deletérios com idade de início geneticamente determinada (o conjunto dos quais é chamado de mortalidade intrínseca ou MI), duas previsões essenciais resultam:

1. a existência da ME basta para a produção de populações com estrutura etária em que as frequências dos indivíduos com idade cai progressivamente e

2. fenótipos deletérios de manifestação precoce estão mais sujeitos à força de seleção do que aqueles de manifestação mais tardia, os quais podem ser fixados por deriva genética (Rose, 1991).

A primeira previsão foi observada em todas as simulações e em ambos os modelos, em que populações inicialmente desprovidas de qualquer estrutura etária, expostas a uma ME constante rapidamente estabeleceram estruturas etárias em que indivíduos mais jovens são os mais prevalentes; um decaimento progressivo idadedependente na frequência dos indivíduos esteve sempre presente (Figura 5.7).

A segunda previsão é um corolário do efeito da estrutura etária sobre a força da seleção natural: uma vez que a população é majoritariamente constituída por indivíduos jovens, estes têm maior probabilidade de contribuir com as futuras gerações do que os indivíduos mais velhos. Efeitos deletérios atuando em idades mais precoces 
devem sofrer seleção mais forte do que aqueles atuando em idades posteriores. Em outras palavras, em populações com estrutura etária, há uma assimetria na força da seleção natural de idade natural, que cai com a idade(Medawar, 1952; Hamilton, 1966). Assim, uma redução na prevalência de alelos deletérios que se manifestam em faixas etárias jovens é equivalente a um aumento pronunciado na aptidão da população. Por outro lado, alterações na prevalência dos genes cujos efeitos se manifestem em indivíduos mais velhos podem causar efeitos potencialmente indetectáveis sobre a aptidão da população.

Também é importante ressaltar que, no modelo ora introduzido, a prevalência de novos alelos gerados por mutações está sujeita às ações da seleção e da deriva genética aleatória. Como observado por Charlesworth, mesmo um alelo vantajoso pode ser perdido por deriva, especialmente ao longo das primeiras iterações depois de seu surgimento, quando a sua prevalência é baixa; por outro lado, até mesmo um alelo deletério pode ser fixado por deriva (Charlesworth, 2009). Sob influência de fenômenos estocásticos, variantes do alelo original podem ser incluídas ou removidas da população, sob ação de seleção ou deriva genética. Neste sentido, o modelo computacional atual utiliza uma estrutura populacional essencialmente equivalente ao modelo populacional descrito por Felsenstein, com tamanho constante, sobreposição de gerações e taxas de mortalidade e natalidade idade-dependentes (Felsenstein, 1971), com os acréscimos mencionados no Capítulo 4. Com exceção da recombinação (pois o modelo assumiu organismos haplóides), todos os processos evolutivos relevantes em genética de populações estão presentes no modelo.

Desta forma, não esperávamos que os valores da MIMED fossem indefinidamente empurrados para idades mais avançadas, como a análise isoladamente por aptidão relativa $\left(W_{r e l}\right)$ nos faria inicialmente imaginar. Ao contrário. esperávamos 
que a MIMED subisse com uma tendência para uma idade hipotética, na qual a força da seleção, em queda, chegaria a um equilíbrio com as pressões exercidas pelas mutações recorrentes e pela deriva genética. Isto é exatamente o que aconteceu, tendo sido claramente observado nas simulações conduzidas a partir do nosso modelo final.(Figura 5.7).

Por ser compatível com os fenômenos de seleção, mutação e deriva genética, o presente modelo é compatível com a idéia central da hipótese dos alelos infinitos (Kimura; Crow, 1964; Crow; Maruyama, 1971). Por isto, não esperávamos uma rápida eliminação dos alelos de manifestação mais precoce em favor dos variantes de manifestação mais tardia. Tampouco esperávamos que a distribuição de alelos evoluísse para um único ou poucos alelos favorecidos, afinal, a hipótese dos alelos infinitos prevê uma distribuição de alelos variantes gerados por mutação. No equilíbrio de tal distribuição, o número de alelos sustentado pela população e seu efeito médio é resultado da combinação dos efeitos da seleção, do input mutacional e da deriva.

Em nossas simulações, tal distribuição entrou em equilíbrio em torno de uma MIMED aproximadamente na idade correspondente à expectativa de vida máxima de cada população estruturada por uma mortalidade total que tendeu à $\mu_{e}$ correspondente.

Também esperávamos que esta evolução fosse conduzida pelo processo de seleção direcional com força progressivamente menor à medida que os valores de MIMED se aproximassem da expectativa de vida máxima da população (ainda que neste processo, devido à queda na mortalidade geral no sentido dos valores de $m u_{e}$, a expectativa de vida máxima subisse). Isto é de fato o que observamos (Figura 5.6). Interessantemente, apesar de nosso modelo utilizar valores fixos para $m u_{i}$, de certa 
maneira, a coleção de alelos mutantes em uma população se comporta como uma característica quantitativa de mortalidade.

Como consequência, mesmo considerando-se apenas os mecanismos previstos pela teoria do acúmulo de mutações, quando os elementos mencionados da genética de populações são adicionados, os efeitos deletérios não são completamente adiados para uma idade muito avançada. Ao contrário do que esperava, mesmo Medawar, em seu mecanismo, haveria indivíduos que expressam os efeitos deletérios em idades precoces, dinamicamente evoluindo nas populações.

Vale ressaltar que, conceitualmente, a evolução da senescência neste modelo não é o surgimento de uma ou mais características deletérias na população, dado que a presença de genes deletérios foi uma imposição do modelo, mas as dinâmicas pelas quais a seleção, diante do influxo constante de variação, falha progressivamente a partir de certas idades em selecionar alelos de idades mais avançadas. Os resultados mostraram que a média das idades de manifestação selecionadas para cada conjunto de simulações em geral tende a uma assíntota que ocorre em idades em que ainda existe um número significativo de indivíduos. Isto significa que, da mesma forma que na natureza, pelo próprio mecanismo evolutivo é de se esperar que existam indivíduos manifestando os chamados "genes deletérios".

Caso a seleção não estivesse como, teorizado por Medawar e Williams, caindo em eficiência, não esperaríamos uma queda na velocidade de seleção dos alelos (representada pela nítida desaceleração das médias das idades de manifestação do componente deletério em todas as simulações). Alternativamente esperaríamos que a seleção levasse em ritmo uniforme as idades de manifestação dos efeitos deletérios para idades muito avançadas, ao menos idades a partir das quais não encontraríamos, nas mesmas simulações, indivíduos vivos em número significativo. 
No entanto, um olhar mais atento à Equação 2.19 nos mostra que o efeito seletivo $S$ do nosso alelo deletério na idade $x$ é dado por $S_{x}=m_{x} p_{x}$, onde a magnitude $m_{x}$ será sempre a mortalidade intrínseca $\left(\mu_{i}\right)$ manifesta na idade $x$ (desde que superior à idade de manifestação $a *$ para qual o alelo foi mutado) e $p_{x}$, simplesmente a proporção de indivíduos que chegam à idade $x$, ou seja $p_{x}=\ell_{x}$. Esta última afirmação é verdade porque em nosso modelo não consideramos senescência reprodutiva (isto seria criar um modelo ad hoc e, portanto, falho, para o estudo em questão).

Assim, é lógico esperar que em um modelo populacional com estrutura etária como o nosso, o efeito seletivo dos alelos mutantes caísse para idades de manifestação mais tardias. Isto é apenas refrasear Medawar (um alelo mutante com a mesma magnitude $m$ que o gene original e $a *$ mais tardio será sujeito a menor força de seleção do que o gene original, tendo maior probabilidade de se fixar na população) ou Williams (efeitos deletérios menores - lembremos que, se $a *<a *^{\prime}$, então $p_{a *}>p_{a *^{\prime}}$ e, portanto, para $m_{a *}=m_{a *^{\prime}}$, segue-se que necessariamente $S_{a *}>S_{a *^{\prime}}$, com queda na intensidade de seleção sobre tal efeito).

Como já exposto, em todas as simulações elencadas nesta tese, iniciamos a idade crítica $a *$, associada ao início de manifestação dos efeitos deletérios do nosso gene em estudo, em 0. Portanto, no início das simulações, a mortalidade total $\mu$ por ciclo foi sempre representada por $\mu=\mu_{e}+\mu_{i}$.

Essas simulações sugerem que, se um traço deletério é regulado por um gene que pode mutar sua idade de expressão, então a seleção poderia favorecer expressões para idades mais avançadas. Este modelo também pode ser interpretado como representando uma população selvagem que adquiriu um mecanismo de proteção que repararia parcialmente danos somáticos (a mortalidade intrínseca do modelo), adiando progressivamente a manifestação fenotípica de tais danos. Sob ambas as 
interpretações, o acúmulo de mutações provoca uma coincidência entre o envelhecimento cronológico e a senescência.

No segundo modelo pudemos observar a ocorrência da seleção. Diante de um influxo de mutações sobre uma característica deletéria fixa ex hypothesi, a distribuição dos variantes em torno de uma moda que progressivamente deixa sua origem e assume valores sucessivamente distintos é reflexo do fenômeno de seleção direcional (Futuyma, 1998).

Como vivos, a força da seleção direcional depende diretamente da magnitude do efeito da mutação em questão, benéfico ou prejudicial sobre a aptidão de seu portador 2.4. Este efeito pode ser calculado pelo coeficiente seletivo desta mutação. Para nosso modelo, no entanto, vale uma observação mais direta.

A situação em que o aumento na moda dos alelos foi máximo para o tempo $t_{f}$, (Painel E da Figura 5.7) representa para este conjunto de simulações, a máxima oportunidade adaptativa. Isto porque a situação retratada, a de evolução sob $\mu_{i}=$

$10^{-1}$ e $\mu_{e}=10^{-2}$ significa, ao menos potencialmente, que esta população poderia evoluir uma mortalidade uma ordem de grandeza menor do que a mortalidade inicial.

\subsubsection{Tamanho populacional efetivo $\left(N_{e}\right)$ e força da seleção}

Esperávamos que a mortalidade global caísse devido à seleção e causasse um aumento monotônico no $N_{e}$ ao longo do processo seletivo. A mortalidade em média de fato caiu, como resultado do adiamento do início da mortalidade intrínseca, e, como tal, esta queda de mortalidade tem de ter pressionado por uma subida no $N_{e}$ desde o início das simulações. O comportamento do $N_{e}$, no entanto, foi substancialmente diferente: após um período inicial de estase, caiu até um valor mínimo e logo subiu para um platô final, em que exibiu os seus valores máximos para cada 
conjunto de parâmetros em simulação.

Ao somarmos na Equação 4.6 da idade 0 até a idade $a$ em vez de ir até $\infty$, obtemos o tamanho populacional efetivo de todos os indivíduos cuja idade seja $\leqslant a$, o qual poderemos denominar $N_{e(\leqslant a)}$ para diferenciar do $N_{e}$. A diferença entre estes valores $\left(N_{e}-N_{e(\leqslant a)}\right)$ equivale ao tamanho populacional efetivo de todos os indivíduos cuja idade é maior que $a$ (que podemos denominar $\left.N_{e(a)}\right)$.

Como esperado, para qualquer conjunto de valores dos parâmetros $\lambda, \mu_{e}$ e $\mu_{i}$, as subpopulações mais idosas contribuem muito pouco para o valor de $N_{e}$, de modo que $N_{e(a)}$, para uma idade $a$ avançada, será necessariamente muito pequeno em relação ao $N_{e}$. Como a intensidade da deriva genética é inversamente proporcional ao tamanho populacional efetivo, levantamos a hipótese de que a capacidade da deriva genética em determinar a evolução dos alelos mutantes aumenta à medida que aumentam os valores das MIMED (e, consequentemente caem os tamanhos efetivos $N_{e(a)}$ das subpopulações que potencialmente expressarão o efeito deletério)

Esta noção formaliza a queda da força da seleção em termos de $N_{e}$ e da idade de manifestação da característica sob seleção, uma vez que quanto maior a intensidade da deriva genética, tanto menor a força de seleção em oposição a esta.

Resta explicar a queda apresentada pelo $N_{e}$ ao início das simulações. Nestas, todos os indivíduos iniciaram com a idade de manifestação do gene deletério em zero e, portanto, cada simulação começou com a maior mortalidade populacional possível para os parâmetros em análise. A queda da mortalidade, por si só, deveria contribuir com o aumento do $N_{e}$. Nossa hipótese para uma queda no $N_{e}$ concomitante à queda na mortalidade é a de que outra influência esteja atuando Como as taxas de mutação são fixas em cada série de simulações (só podendo ser determinada no início das simulações), então a única explicação que podemos sugerir para a queda inicial do 
$N_{e}$ é uma variação inicial na força da seleção.

De fato, sob grandes flutuações nas frequências dos extratos etários (que observaríamos sob ação combinada de mutações e seleção), é esperado que $N_{e}$ deveria diminuir. Se este foi o caso nas presentes simulações, é possível que os valores mínimos de $N_{e}$ marquem o momento de máxima força de seleção e (devido à esperada queda na força de seleção relacionada às maiores idades de manifestação) este momento de máxima seleção tem de ter ocorrido enquanto as MIMED ainda coincidem com as idades mais baixas, de modo a evolver os grupos etários mais numeros, que são justamente aqueles mais jovens.

Neste cenário, após um momento de máxima seleção, a MIMED já estava avançada o suficiente para que os grupos etários sob ação da seleção fossem os grupos etários mais idosos e, como previsto nas teorias de Medawar e Williams, a força de seleção tinha de começar a cair.

Neste momento, a seleção em queda associa-se com mortalidade descrecente da população (sempre em queda desde o início) causando o aumento de $N_{e}$.

Dentro deste raciocínio, no momento em que observamos que $N_{e}$ atingiu seu valor máximo, sabemos que a força de seleção se tornou mínima. Eventuais mutações que adiassem a MIMED para idades ainda mais avançadas corresponderiam a mutações neutras. Por isto, a MIMED não pode mais aumentar e a mortalidade média da população não pode mais cair. Uma vez que os dois componentes que influenciavam $N_{e}$ (mortalidade populacional e força de seleção) se tornaram fixos, $N_{e}$ se tornou estável em seus valores máximos para cada conjunto de parâmetros, marcando o momento de equilíbrio evolucionário.

É fácil suspeitar de que o processo de seleção seja dinâmico, uma vez que o resultado da seleção por idades de manifestação mais tardias do componente de- 
letério diminuem a mortalidade geral da população, aumentam sua longevidade e mudam o próprio valor seletivo da mutação selecionada.

Embora por estas razões o processo seletivo em cada condição experimentada caminhe muito lentamente para um estado de equilíbrio, também é fácil entender que o sistema caminhe assintoticamente para um limite. Isto é demonstrado graficamente na Figura 5.2). Uma vez que todas as simulações começaram com os indivíduos manifestando o componente deletério na idade zero, a mortalidade inicial medida se aproximou muito da soma das mortalidades extrínseca e intrínseca, como era de se esperar. Como houve seleção por idades de manifestação progressivamente mais tardias, houve queda da mortalidade geral (como já discutimos). É interessante notar que, para cada simulação, a mortalidade caiu, tendendo assintoticamente aos níveis da mortalidade extrínseca, acompanhada de modificações progressivamente nas idades médias de manifestação do componente deletério do gene em seleção e na distribuição etária de cada população.

Isto faz todo o sentido, pois a seleção terá de se equilibrar também com a deriva genética aleatória, que elimina novas mutações mesmo se forem benéficas e podem colaborar aleatoriamente com a fixação de outras, inclusive as deletérias (Gillespie, 1998)

\subsubsection{Evolução das distribuições de alelos por idade de ma- nifestação}

As teorias de Medawar e Williams não abordam explicitamente os efeitos da deriva genética nas situações que prevêem, contando com a eficiência da seleção (ou falta dela) para chegar às conclusões descritas nas Seções 2.5 e 2.6. A eficiência da seleção pode ser estimada em função do tamanho efetivo da população $\left(N_{e}\right)$ a cada 
momento.

A distribuição etária das populações em $t_{f}$ reflete diretamente a distribuição das idades de manifestação (DA) subjacentes a cada condição sob simulação (Figura 5.7). Da idade zero até a moda das idades de manifestação, a inclinação da estrutura etária em $t_{f}$ reflete exclusivamente a mortalidade extrínseca (ou seja, equivale à inclinação da distribuição etária que seria obtida com um valor fixo de $\mu=\mu_{e}$. A partir deste ponto, a distribuição etária em $t_{f}$ recupera a inclinação que apresentava em $t_{0}$, quando $\mu=\mu_{e}+\mu_{i}$ (por exemplo, na Figura 5.7), com $\mu_{e}=10^{-2}$, $\mu_{i}=10^{-2}$ e $\left.\mu_{e}=10^{-2}, \mu_{i}=10^{-1}\right)$. Isto significa que, em $t_{f}$, para idades abaixo da moda das idades de manifestação dos alelos (valor próximo às MIMED calculadas na Figura 5.6), $\mu \approx \mu_{e}$. Portanto, ainda que existam alelos na população para idades de manifestação < MIMED, o efeito deletério do gene em análise já está efetivamente eliminado para as idades abaixo da MIMED. Esta é a razão pela qual as distribuições etárias em $t_{f}$ apresentam uma mudança abrupta de comportamento, a qual corresponde à transição entre as duas inclinações que a curva ainda apresenta. Logicamente, o ponto de transição entre estas duas inclinações coincide com a moda da distribuição das idades de manifestação dos alelos. No entanto, estas distribuições etárias "quebradas" ou com duas inclinações indicam que as populações correspondentes não atingiram o $N_{e}$ máximo e ainda têm potencial para evolução sob um regime não neutro após $t_{f}$. As curvas correspondentes podem ser observadas na Figura 5.8). Para $\mu_{e}=10^{-2}$ e $\mu_{i}=10^{-2}$ (Figura 5.8), curva vermelha), o valor de $N_{e}$ ainda estava subindo em $t_{f}$, não tendo chegado ao seu máximo. Por outro lado, para valores de $\mu_{e}=10^{-2}$ e $\mu_{i}=10^{-1}, N_{e}$ ainda estava muito aquém de seu valor máximo em $t_{f}$ (Figura 5.8), curva amarelo escura) e a distribuição das idades de manifestação ainda apresentava um longo percurso para se deslocar, ainda que lentamente, para idades mais avançadas (Figura 5.7). Em algumas combinações de 
parâmetros, a distribuição etária atingiu o limite $\mu=\mu_{e}$ e, portanto, nenhum comportamento "quebrado" na sua inclinação foi aparente (por exemplo, na Figura 5.7, para $\mu_{e}=10^{-1}$ e $\mu_{i}=10^{-1}$ ), tendo $N_{e}$ atingido seu máximo, como pôde ser verificado no painel correspondente na Figura 5.8, na curva amarelo escura.

A evolução da mortalidade total em direção ao valor da mortalidade extrínseca era esperada, devido ao aumento adaptativo associado desse processo. Como tal, o aumento da MIMED tendeu a ser maior para as simulações com menores valores de $\mu_{e}$ em relação à $\mu_{i}$. Maiores taxas de mutação estiveram correlacionadas com evolução para maiores idades de manifestação.

Como esperado, a este ponto a MIMED tende à idade do indivíduo vivo mais velho, determinada pela mortalidade média da população, a qual cairá na direção de $\mu_{e}$; o melhor equivalente do estado de equilíbrio do sistema será obtido quando $\mu=$ $\mu_{e}$. Uma vez que este equilíbrio for atingido, o efeito deletério estará efetivamente eliminado nas populações, mas não nos indivíduos. Como a distribuição de alelos por idades de manifestação mostraram, mesmo quando tal equilíbrio foi alcançado (por exemplo, na Figura 5.7, painel direito inferior), haverá alelos individuais com idades variando desde valores inferiores à moda no equilíbrio. Este é o efeito da deriva genética aleatória e consideramos este efeito essencial para a compreensão da evolução da senescência.

\subsubsection{Os efeitos combinados da mortalidade e da mutação}

Para melhor entender a dinâmica do processo em evolução, procedemos à análise dos possíveis efeitos das diferentes combinações dos níveis de mortalidade e mutação. Consideremos as evoluções das MIMED (A), mostrada na Figura 5.6, e do número médio de genótipos $(D)$, mostrados na Figura 5.9. Em contraste com os 
casos neutros (painéis superiores das Figuras 5.7, 5.6 e 5.9), para certos conjuntos de valores foi possível distinguir dois tipos de evolução no tempo, essencialmente definidos pela magnitude do influxo mutacional. Este é definido como o número esperado de mutações por ciclo e, como em nosso modelo de população fixa a natalidade equivale à mortalidade, é dado por $N \mu \lambda$. Comparando as distribuições etárias na Figura 5.7 para as situações em que $\mu_{e}=10^{-2} / \mu_{i}=10^{-2}$ com $\mu_{e}=10^{-2} /$ $\mu_{i}=10^{-1}$, observamos que a inclinação em $t_{f}$ abaixo da moda de $A$ no mesmo tempo é semelhante em ambas as curvas. Esta inclinação tem de ter sido determinada apenas por $\mu_{e}$, já que esta é a mesma para ambas as situações. De fato, no caso neutro $\left(\mu_{i}=0\right)$ em que $\mu_{e}=10^{-2}$, a totalidade das inclinações das distribuições etárias tanto em $t_{0}$ quanto em $t_{f}$ são também similares às inclinações para os casos mencionados. Isto quer dizer que as mudanças de inclinação das curvas de distribuição etária resultam do deslocamento das distribuições das idades de manifestação dos alelos existentes desde baixas idades até idades de manifestação mais altas, deixando progressivamente mais grupos etários sujeitos apenas a $\mu=\mu_{e}$. Os alelos presentes na população estão evoluindo para a neutralidade seletiva da característica deletéria em seleção.

Uma situação muito diversa apareceu nas situações em que $N \mu \lambda \approx 1$. O comportamento liso de $D$ ao longo da evolução perdeu-se e este exibiu uma "quebra" em um certo tempo $t_{c}$ (Figura 5.9), curvas inferiores). Além disto, $A$ possui uma inflexão por volta de $t_{c}$, correspondendo à aceleração da seleção da idade de manifestação (Figura 5.6, painéis inferiores) se comparada com a situação em que $N \mu \lambda \gg 1$.

A explicação para esta mudança não esteve aparente até que observamos a distribuição das idades de manifestação para estes casos. Esta corresponde, ao casos 
mostrados na Figura 5.7, em que $\mu_{e}=10^{-2} / \mu_{i}=10^{-2}, \mu_{e}=10^{-2} / \mu_{i}=10^{-1}$ e $\mu_{e}=10^{-1} / \mu_{i}=10^{-1}$. Nestes casos, a seleção foi forte o suficiente para superar a pressão de mutações recorrentes e eliminar alelos com as menores idades de manifestação. Estas distribuições de idades de manifestação, assim, adquiriram um novo formato, essencialmente simétricas em escala logarítmica, e passaram a "caminhar"para maiores valores das idades de manifestação. Embora não tenhamos registrado uma sequência completa destes eventos por motivos práticos, consideramos que este raciocínio é uma simples inferência a partir dos dados efetivamente registrados. Sabemos, por exemplo, que para mortalidades fixas, um aumento no influxo mutacional pode acelerar a evolução no sentido do $N_{e}$ máximo. Consequentemente, comparando as distribuições no tempo $t_{c}$ e a evolução de $N_{e}$ no tempo, podemos avaliar acuradamente se uma determinada população atingiu todo o seu potencial evolutivo.

Podemos também inferir como tal processo ocorreu. Em todas as simulações em que alelos expressando $\mu_{i}$ na idade 0 ainda estavam presentes no tempo $t_{f}$, nenhuma "quebra" foi observada na Figura 5.9; por outro lado, sempre que os últimos alelos para a idade de manifestação do efeito deletério $=0$ foram eliminados, uma quebra aparece, correspondendo ao momento em que a distribuição das idades de manifestação adquire um formato simétrico (impossível quando ainda existem, no início da curva, alelos para idades de manifestação $=0$ ) e neste mesmo momento os valores da MIMED aceleram na sua evolução para idades mais avançadas (Figura 5.6). Também interessante foi o comportamento da moda das distribuições das idades de manifestação de alelos para diferentes valores de $\mu_{i}$. A Figura 5.7 mostra que, mantidos os mesmos valores $\mu_{e}, t_{f}$ e $\lambda$, quanto maior o valor de $\mu_{i}$, mais rápida a evolução das idades de manifestação. 
É precisamente a transição a partir de uma forma neutra que explica a existência da quebra da curva em $D$ e da aceleração no ritmo de aumento de $A$ próximo ao tempo $t_{c}$. Independente disto, o resultado final do processo é o mesmo para todos os casos: os valores das MIMED aumentarão até que cada população atinja seu $N_{e}$ máximo, correspondendo à chegada à mínima mortalidade possível $\left(\mu=\mu_{e}\right)$ e à neutralidade seletiva. Após atingir este ponto, a distribuição de alelos por idades de manifestação começa a acumular variantes aleatoriamente, sujeita unicamente à deriva genética. Assim, a distribuição de alelos perde sua simetria e desenvolve uma cauda neutra nas idades mais avançadas (visível na Figura 5.7, no painel inferior direito). Esta é categoricamente a parte do acúmulo de mutações na teoria de Medawar-Williams.

Em seu influente livro sobre a genética da seleção natural, Fisher dedica um capítulo ao que chamou de O teorema fundamental da Seleção Natural, originalmente formulado como "a taxa de aumento na aptidão de qualquer organismo num dado tempo é igual à sua variância genética sobre a aptidão neste mesmo tempo" (Fisher, 1930, Capítulo 2). Por cerca de 40 anos, acreditou-se que Fisher postulava que a seleção natural sempre aumentaria a aptidão de uma população (como se acredita leigamente até os dias atuais), o que tornou o teorema de Fisher sujeito a controvérsias e mesmo descrédito desde sua formulação. Em 1972, no entanto, o teorema de Fisher foi matematicamente demonstrado por Price e é atualmente enunciado como "a taxa de aumento na aptidão médio de uma população devido a mudanças de frequência genética é exatamente igual à variância genética aditiva na aptidão" (Edwards, 2002).

O comportamento da velocidade de evolução no presente modelo (descrito na Seção 5.2.3.1) foi compatível com esta formulação, uma vez que foram as simu- 
lações com maior influxo mutacional, representadas por $N \mu \lambda \gg 1$, aquelas em que a MIMED aumentou mais rapidamente.

\subsection{O Efeito da Mortalidade Extrínseca}

Em ambos os modelos computacionais, nos maiores níveis de $\mu_{e}$ foram observadas as estruturas etárias mais jovens (Figura 5.1 para o Modelo inicial e Figura 5.7 para o modelo final. Tal resultado era claramente esperado e, por consequência, esperávamos menores valores de equilíbrio para as MIMED nas simulações com os maiores valores de $\mu_{e}$.

A importância da magnitude da mortalidade extrínseca tem sido reconhecida na literatura há tempos: embora seja geralmente aceito que as teorias evolutivas da senescência implicam que maiores mortalidades extrínsecas serão correlacionadas com estruturas populacionais mais jovens e, consequentemente, com maiores taxas de senescência (Hamilton, 1966), experimentos têm apresentado resultados muito difíceis de interpretar, com taxas de senescência maiores em um subconjunto da população do que em outros (Williams; Day, 2003); diferentes grupos etários podem ter diferentes suscetibilidades à mortalidade extrínseca (Charlesworth, 1980); finalmente, o aumento da mortalidade extrínseca poderia até aumentar a disponibilidade de recursos para os sobreviventes por diminuir a densidade populacional (Abrams, 1993).

É difícil estudar o efeito da mortalidade extrínseca em um ensaio biológico. Em um ensaio cuidadosamente projetado, a título de exemplo, Reznick e colaboradores identificaram duas subpopulações naturais de lebistes (Poecilia reticulata) de Trinidad evoluídas ambientes diferentes, com e sem predadores. Interpretou-se que tais subpopulações estivessem naturalmente expostas, respectivamente, a alta e 
baixa mortalidades extrínsecas. Ao contrário do esperado, lebistes sob baixa mortalidade extrínseca (sem predadores) apresentaram maior incremento etário na mortalidade (senescência) em comparação com lebistes evoluídos em ambiente de alta predação (Reznick et al., 2004).

Outros fatores, no entanto, podem estar atuando: por exemplo, embora a mortalidade dos peixes sob baixa predação seja muito menor, eles vivem sob carência alimentar muitas vezes maior do que os peixes sob alta predação, porque a baixa predação permite uma ocupação muito maior do ambiente pelos peixes, com consequente falta de alimento. A redução da mortalidade extrínseca a sinônimo da mortalidade por predação pode ser uma simplificação exagerada, pois é esperado que populações submetidas a alta predação tenham mais recursos energéticos disponíveis do que populações sob menor predação, já que a alta mortalidade por predação exerce um controle sob a densidade da população, diminuindo a mortalidade por fome, que é, junto com a predação, um importante componente da mortalidade extrínseca ((Abrams, 1993)).

No exemplo específico, a ausência de predadores pode ser uma razão para superpopulação (de fato os autores do estudo citado mostram que a densidade populacional é muito mais alta no ambiente sem predação) e a mortalidade pela fome, que deve ser considerada um componente extrínseco de mortalidade, muito maior no ambiente sem predação. A própria mortalidade por fome, a meu ver, poderia, constituir uma pressão evolutiva para a seleção de organismos com menor gasto energético na manutenção somática, por exemplo. Por outro lado, lebistes evoluídos em ambientes de alta predação poderiam co-evoluir com seus predadores, num clássico fenômeno conhecido por "corrida armamentista evolucionária“, em que presas sucessivamente melhores em evitar a predação exercem pressão evolutiva por predadores 
sucessivamente mais eficientes e vice-versa. Neste cenário, a maior disponibilidade de recursos energéticos (causada pela menor densidade populacional) permitiria a evolução de lebistes mais vigorosos e com nado mais veloz (de fato, neste mesmo estudo, lebistes coletados no ambiente de alta predação possuíam estas características em comparação com aqueles coletados no ambiente sem predadores). Criar ensaios biológicos que comparem níveis distintos de mortalidade extrínseca, mantendo idênticas todas as outras condições relevantes definitivamente não é tarefa simples.

Na medida em que maiores mortalidades extrínsecas se correlacionaram com estruturas populacionais mais jovens e menores idades médias de manifestação do componente deletério no estado de equilíbrio, nossos resultados estão de acordo com o esperado teoricamente (Hamilton, 1966; Ricklefs, 1998). Além disso, os resultados ora discutidos podem reforçar a importância dos modelos simulados na concepção de modelos experimentais como o acima referido, sujeito a vieses de interpretação e à dificuldade em classificar o que pode é mortalidade extrínseca e o que pode ser considerado senescência, e não uma adaptação a uma condição evolutiva clássica.

\subsection{O Efeito da Mortalidade Intrínseca}

Em nosso trabalho, maiores níveis de $\mu_{i}$ estiveram correlacionados com evolução mais rápida para neutralidade seletiva, com o avanço das MIMED. Isto é razoável, porque - todo o restante mantido igual - o valor seletivo de uma nova mutação será maior para um gene com uma maior $\mu_{i}$ e, sob as mesmas forças de seleção, estarão sujeitos a uma evolução mais rápida.

Este efeito da intensidade relativa de $\mu_{i}$ sobre a seleção pode ser importante no contexto da evolução da senescência: dado que nossas simulações necessitaram 
de um grande número de gerações para evoluir neutralidade nos casos mais rápidos e esta sequer foi atingida em $10^{6}$ ciclos para os valores mais baixos de $\mu_{i}$ (Modelo 2), o tempo evolutivo necessário para alcançar a neutralidade no âmbito do mecanismo do acúmulo de mutações pode ser enorme, especialmente para mutações deletérias de menor efeito. Mutações deletérias sobre múltiplos loci podem estar em diferentes fases do processo evolutivo aqui descrito, dependendo de sua intensidade e por quantas gerações estão presentes.

Desta forma, propomos a hipótese de que o início precoce da senescência, como observável na natureza, pode ser pelo menos parcialmente explicado pelo acúmulo de mutações deletérias em loci diferentes e com distintas diferentes distribuições dos alelos segundo as idades de manifestação em cada locus gênico. Ao melhor de nosso conhecimento, a potencial importância do efeito da intensidade de $\mu_{i}$ relativa à mortalidade total sobre a seleção não tem sido devidamente considerada pela literatura sobre a evolução da senescência.

\subsection{Considerações finais}

Em nossas simulações, no estado de equilíbrio evolutivo, foi a moda da idade de manifestação do efeito deletério dos genes em evolução que estabilizou próximo à idade máxima. As populações em estado de equilíbrio suportaram um grande número de alelos distintos, mantidos em polimorfismo. Em alguns casos, alelos com idades iniciais de manifestação do efeito deletério em torno da moda se estenderam até idades surpreendentemente precoces para a estrutura etária destas populações. Isto está de acordo com o modelo de alelos infinitos. Neste contexto, nosso modelo sugere, unicamente utilizando a teoria do acúmulo de mutações, uma explicação para a observação da senescência mesmo em populações selvagens. 
Considerando-se os resultados do dois modelos apresentados, sugere-se que a neutralidade seletiva para um mecanismo de acúmulo de mutações somente é encontrada em idades muito avançadas, em que não encontraríamos nenhum animal vivo na natureza. Esta foi, como vimos, a própria interpretação de Medawar, autor da Teoria do Acúmulo de Mutações.

Ao contrário do que Medawar acreditava, nosso modelo computacional sugere que o mecanismo de acúmulo de mutações per se poderia ser responsável pela manutenção de mutações deletérias de manifestação precoce em populações selvagens. Isto é devido à combinação dos efeitos das mutações recorrentes e da deriva genética atuando aleatoriamente sobre o genoma e em equilíbrio com a força de seleção. 
7 Conclusões 
As conclusões a seguir baseiam-se nos objetivos anteriormente elencados (Capítulo 3). Estes são repetidos em itálico antes das respectivas conclusões.

\subsection{Objetivos Gerais}

1. Desenvolver um modelo computacional que possa ser utilizado para testar hipóteses acerca das teorias evolutivas da senescência. Foi possível implementar um ambiente de simulações computacionais para estudo da evolução da senescência baseado nas técnicas consagradas de computação evolutiva e respeitando as teorias sobre a evolução da senescência (Modelo Final). O modelo computacional proposto foi capaz de mostrar emergência de padrões evolutivos complexos, embora se baseando em regras simples e consensuais; por esta razão, o modelo se mostrou uma ferramenta a ser explorada no estudo evolucionário da senescência.

2. Inferir sobre o impacto de diferentes níveis de mortalidade extrínseca na evolução da senescência. Populações submetidas a maiores níveis de $\mu_{e}$ atingiram idades de neutralidade seletiva mais precoces; isto significa dizer que maiores níveis de $\mu_{e}$ se correlacionaram com senescência mais precoce.

3. Inferir sobre o impacto de diferentes níveis de mortalidade intrínseca na evolução da senescência. Maiores magnitudes de mortalidade intrínseca $\left(\mu_{i}\right)$ relativas à $\mu_{e}\left(\frac{\mu_{i}}{\mu_{e}}\right)$ levaram a seleção mais rápida; nas condições de maior impacto da mortalidade intrínseca $\left(\frac{\mu_{i}}{\mu_{e}} \gg 1\right)$, a idade máxima foi rapidamente atingida, a partir da qual as simulações evoluíram por deriva genética. Finalmente, a idade de neutralidade seletiva não dependeu dos níveis de $\mu_{i}$. 


\subsection{Objetivos Específicos}

1. Avaliar a hipótese de que, sob o mecanismo de acúmulo de mutações, somente genes deletérios de manifestação acima da longevidade máxima possam fixarse em uma população (hipótese de senescência "apenas no laboratório"). Os resultados falsificaram esta hipótese, pois mostraram que, mesmo nas simulações que atingiram a neutralidade efetiva, a distribuição dos alelos presentes comumente incluiu variantes com idades de manifestação bastante precoces.

2. Avaliar a hipótese alternativa de que um gene essencial com efeitos deletérios possa fixar-se em uma idade abaixo da longevidade máxima. Os resultados também falsificaram esta hipótese; na realidade, os alelos com manifestação em idades precoces identificados no estado de neutralidade seletiva se mantiveram presentes nas populações através de um equilíbrio polimórfico, sustentado pelo input mutacional e pela deriva genética.

3. Avaliar o papel da força de seleção sobre o mecanismo de acúmulo de mutações. O tamanho populacional efetivo $N_{e}$ caiu à medida que a seleção por novas variantes aumentava o número de alelos; a seguir, $N_{e}$ aumentou em paralelo à queda na força da seleção, atingindo seu valor máximo sempre que a força de seleção caiu para níveis desprezíveis. Neste momento evolutivo, os genes com efeitos deletérios efetivamente escaparam à força de seleção.

4. Avaliar o papel da deriva genética aleatória sobre o mecanismo de acúmulo de mutações. O Modelo Final demonstrou que o papel relativo da deriva genética aumenta à medida que a força de seleção diminui. No estado de equilíbrio (neutralidade seletiva), a evolução dos alelos se deu unicamente pelos efeitos da deriva genética e do input mutacional. 
5. Descrever a dinâmica de evolução de um gene essencial com efeitos deletérios em diferentes combinações de mortalidades extrínseca e intrínseca com base nas modas das idades de manifestação selecionadas. Esta dinâmica foi descrita nos resultados do Modelo Final para distintas combinações de $\mu_{e}$ e de $\mu_{i}$. A intensidade inicial de seleção foi diretamente influenciada pela magnitude da relação $\frac{\mu_{i}}{\mu_{e}}$, mas a perda de força da seleção, que condicionou os limites evolutivos para o gene em questão, dependeu fundamentalmente de $\mu_{e}$. 


\section{APÊNDICE A -- Artigo Publicado}

Monaco TO, Silveira PSP. Aging is not senescence: a short computer demonstration and implications for medical practice. Clinics (Sao Paulo). 2009, 64(5), 451-7. 


\section{AGING IS NOT SENESCENCE: A SHORT COMPUTER DEMONSTRATION AND IMPLICATIONS FOR MEDICAL PRACTICE}

Thiago Oliveira Monaco, Paulo Sergio Panse Silveira

doi: $10.1590 / \mathrm{S} 1807-59322009000500013$

Monaco TO, Silveira PSP. Aging is not senescence: a short computer demonstration and implications for medical practice. Clinics. 2009;64(5):451-7.

INTRODUCTION: The discussion regarding the evolution of aging is almost as old as Darwinian Evolution Theory, but to date, it has remained one of biology's unresolved problems. One issue is how to reconcile natural selection, which is understood as a process that purges deleterious characteristics, with senescence, which seems to offer no advantages to the individual.

METHOD: A computer simulation that illustrates an evolutionary mechanism for the development of senescence in populations is presented.

DISCUSSION: In this article, we debate that two popular explanations for the existence of senescence, namely, (1) the removal of elders for the benefit of the species and (2) the progressive deterioration of the organic machine due to continuous use, are not correct. While human populations continue to age, it is important that the physician understands that senescence, here defined as the progressive impairment of an organism, does not necessarily accompany aging, which we here define as the mere passage of time. As such, we argue that certain processes that were originally assumed to be part of aging should have their status changed because they are actually diseases. Physicians often encounter situations that depend on a better understanding of what limitations senescence imposes on most living species. The concepts of aging (the unavoidable passage of time), senescence (progressive physiologic impairment), and senility (the pathological development of diseases), are discussed.

KEYWORDS: Evolution; Senility; Cellular automata; Mutation accumulation; Computer simulation.

\section{INTRODUCTION}

Medical practice increasingly deals with elderly patients, whose bodies exhibit decreased functional reserves. Indeed, progressive loss of function is a clinical hallmark of aging. Thus, it is a reasonable assumption for physicians that the senile process is a consequence of the exhaustion of the body's mechanisms. Another common idea is that aging is a benefit for the population, resulting in the removal of elderly individuals in favor of young ones. In this paper, we argue that these are misconceptions. Before we can explore possible mechanisms of senescence, we have to distinguish

Discipline of Medical Informatics (LIM-01), Department of Pathology, Faculdade de Medicina da Universidade de São Paulo - São Paulo/SP, Brazil. Email: thiagomonaco@usp.br

Tel.: 55113064.2744

Received for publication on December 16, 2008 Accepted for publication on February 02, 2009 the concepts of aging, which is the mere passage of time, from senescence, which is the decreasing functionality of an organism. We also define senility, which is the set of pathological processes associated with age. In this context, we argue that simultaneous observations of aging and senescence or senility can be assumed to be coincidental.

The concept of individual exhaustion of the body's mechanisms is not supported because man-made machines are not comparable to biological organisms. Biological organisms self-repair, and a perfect self-repairing mechanism would guarantee aging without senescence. If aging without senescence were impossible and the exhaustion of an organism were unavoidable, then there would be no exceptions within the animal kingdom. However, the Blanding's turtle (Emydoidea blandingii) in captivity has shown decreasing mortality and increasing fertility with aging, as if this species could live in a permanent state of young adulthood. However, this turtle is not immortal, since 
it faces famine, predation, and diseases in nature. ${ }^{1,2}$ It may thus be argued that the organic self-repairing mechanisms of this turtle seem to be permanently functional, while for most other species, perhaps senescence depends not on the progressive exhaustion of body mechanisms but on a programmed failure of repair processes. In fact, evidence for a genetic basis and for the transmission of senescence has accumulated in the literature for decades ${ }^{3,4}$ Our question is: what is the advantage of defective self-repair for natural selection? We seek to identify an advantage that could function at the population level.

The explanation of senescence as a populational mechanism of sacrificing elderly individuals to benefit the whole species was one of the oldest evolutionary ideas, attempting to reconcile Darwinian evolution and senescence as proposed by August Weismann in $1881 .{ }^{5}$ Weismann, however, could not find a Darwinian mechanism for his proposition. His proposition involved a circular argument since it started with the distinction between younger and older individuals in order to explain the origins of the senile process. In addition, animals of species that do not achieve more advanced ages due to predation can exhibit multiple senile phenomena if they are protected in captivity and allowed to live well past their natural average, even though they may have had no opportunity to expose these traits to natural selection in the course of their evolutionary histories. For those reasons, Weismann himself withdrew his hypothesis a few years later, ${ }^{6}$ but his concept is still repeated today in non-specialized literature.

What, then, is senescence? How can we solve the paradox, since it is widely known that Darwinian natural selection purges deleterious features from organisms, and the senile process is clearly non-defensible as some kind of individual improvement? Senescence is defined by increasing mortality and decreasing fertility with increasing age. In humans, the probability of death is typically higher during the first years of life, progressively decreases until the beginning of the reproductive period, and then steadily increases through advanced ages (Figure 1). Fertility has the opposite behavior; it is null until reproductive age, quickly achieves a peak, and then progressively decreases, trending to zero at menopause in women (Figure 1). The greater the rate of mortality increase (or fertility decrease), the quicker are the senescence processes of a species. These processes seem to be genetically conditioned; the progressive frailty associated with senescence is related to an increasing risk of death that has been shown to double over regular time intervals, the so-called mortality rate doubling time (MRDT), as defined by Gompertz. ${ }^{7}$ The MRDT is a species-specific, empirical measurement of the rate of senescence. MRDT is about 0.3 years in mice, 4.1 years in baboons, and 8.3 years in humans. ${ }^{8}$ Mechanisms that interfere with the rate of senescence, therefore, must change the MRDT. Identifying processes that change the MRDT requires locating the mechanisms that are responsible for senescence.

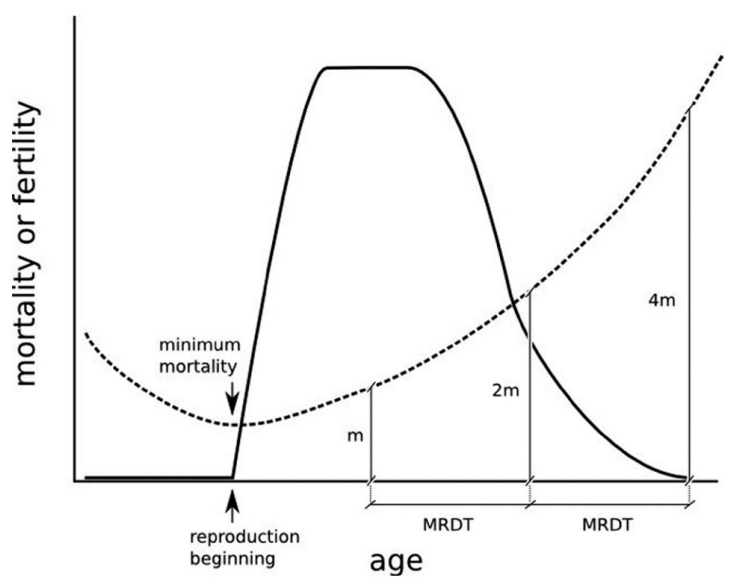

Figure 1 - Hypothetical mortality (dashed line) and fertility (solid line). Mortality decreases from birth to a minimum and then slowly increases with age. In this ascending phase, the probability of death (m) doubles at fixed intervals, which is known as the mortality rate doubling time (MRDT). The beginning of reproduction typically coincides with the minimum mortality, quickly achieves a plateau, and then gradually decreases. Those phenomena are characteristic of a senescent species.

The first competitive evolutionary theory for aging was proposed in 1952 by Medawar and is known as the mutation accumulation theory. ${ }^{9}$ Medawar described a hypothetical population subject to a constant risk of death, which may correspond to predation, starvation, and diseases. This population ages in the sense of passage of time, but it exhibits no senescence in the sense of increased mortality and decreased fertility. The absence of senescence does not imply immortality; instead, due to the accumulated risk of death, this population has far more young individuals than older ones, whose removal would have a negligible impact on general competition for the environment. Medawar therefore proposed that the genetic contribution for the next generation is proportional to the number of individuals that are alive within each age bracket. As such, genes would be more readily exposed to natural selection when expressed in younger individuals, while a deleterious gene could evade natural selection by postponing its expression. This proposition is compatible with Darwinian mechanisms and would cause, over many generations, the accumulation of deleterious mutations and a realignment between the passage of time and senile processes.

In 1957, Williams formalized the antagonistic pleiotropy theory, which proposes that a gene that improves reproduction or survival odds may be favorably selected, 
even if it damages its host later in life. ${ }^{10}$ As such, by the time that the damage is expressed, copies of the genes that cause senescence have already propagated to the next generation. According to Williams' theory, this effect is expected: since most organisms descend from young beings, as Medawar illustrated, the advantage of a minor early benefit that may increase reproductive performance surpasses the disadvantage associated with the much greater damage that may subsequently impair individual robustness.

Although these ideas are not mutually exclusive, difficulties with testing these theories include the multigenerational time scale for evolutionary processes and the paucity of organisms that can be used for experimentation. Therefore, we propose computer simulations. Here we explore Medawar's proposition that natural selection may be inefficient in purging deleterious genes subject to changes in their age of manifestation.

Computational systems that emulate evolutionary rules have been used across different scientific fields, with surprisingly encouraging results. ${ }^{11-14}$ For this study, we developed a computational environment to test the mutation accumulation theory of senescence. Although simple, this model is a demonstration of the progression of a deleterious gene to older ages, as suggested by Medawar. In this context, senescence is interpreted as the summation of many deleterious features that may have been pushed to older ages by Darwinian mechanisms. We argue that understanding this interpretation may be helpful in refining a physician's perspective of disease.

\section{METHODS}

A computer-based approach is an alternative means of testing a theory. It involves simulating a huge number of generations, which would not be feasible given any experimental observation window. For example, the average time of sexual maturation of fruit flies (Drosophila melanogaster) is two weeks. In a simulation where sexual maturation is achieved with forty cycles, the simulation of 800,000 cycles roughly equates to 20,000 generations of fruit flies, corresponding to 766 years of experimentation.

We developed a simple computational model. The environment is represented by a square region that contains digital organisms and simulated food (Figure 2). Each organism is subjected to simple rules defining its movement, feeding, reproduction, and death. These rules are repeatedly applied at every simulation cycle. For instance, the rule for movement changes the position of the individual from its current position to another random position inside a given radius defined by the researchers. Rules for feeding include the environmental distribution of energy units, which each organism can absorb from its surroundings over a given radius. Reproduction depends on contact between males and females of reproductive age. Death features two components: extrinsic mortality, which includes a constant probability of death and starvation due to a lack of energy absorption, and intrinsic mortality, which is the probability of death conditioned by a deleterious gene.

This deleterious gene is the mimicry of the senescent condition. We started all simulations with the deleterious gene expressed at birth. When expressed, the probability of death of its host is the summation of extrinsic and intrinsic mortality. These genes can mutate throughout the simulation. Competing lineages of genes with different ages of manifestation thereby emerge.

\section{Environment}

The environment has periodic boundary conditions, namely, the continuation of the eastern border with the western border and of the northern border with the southern border of the square. This is a condition usually applied to this kind of system to avoid the interference of border effects. Energy units are periodically generated and randomly placed in the environment (Figure 2).

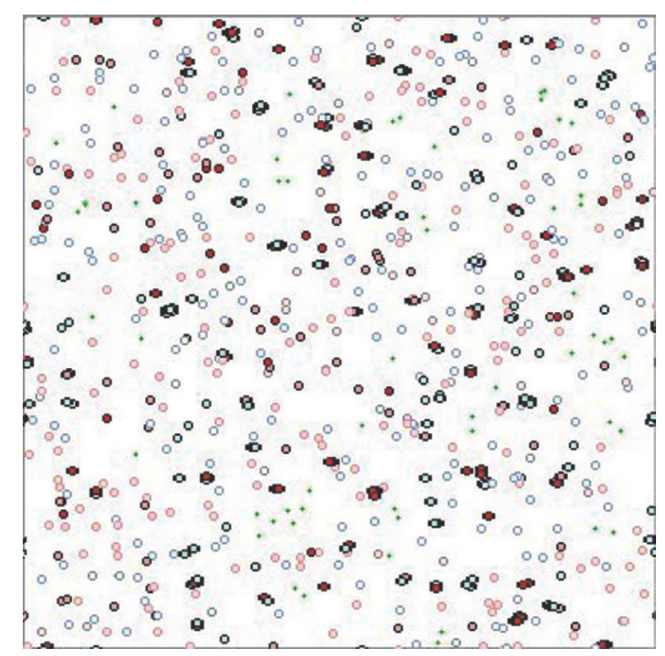

Figure 2 - Visual rendering of the simulated environment. Small dots represent food units, and circles represent individuals. Individuals are depicted in several colors depending on gender, age, and status: blue for males, red for females; pale or intense colors respectively for individuals before and at the onset of reproductive age. Red circles with lateral dots are pregnant females.

\section{Organisms}

Each individual has a collection of variables defining its: - position in the environment; 
- gender (male or female);

- reproductive conditions;

- genotype;

- energy reserve;

- age.

Those variables are changed at every cycle by the rules described above.

\section{Simulations}

The system stores a number of variables to allow the reconstitution of the evolutionary history of each simulation and generates an HTML file to allow visual control by the researcher. We initially conducted a number of preliminary simulations to identify conditions to maintain a stable population. The following conditions were applied to our demonstration:

- Environment: 350 x 350 with periodic boundary conditions;

- 700 units of food per cycle;

- Area for food searching: up to 10 units from an individual's location;

- Individual movement: up to 8 units distant from a current location;

- Area for sexual partner searching: up to 15 units from an individual's location;

- Energy spent per individual: 1 unit per cycle;

- Extrinsic mortality: $0.3 \%$ per cycle;

- Intrinsic mortality (in addition to that associated with gene expression): $1.2 \%$ per cycle;

- Initial age of expression of the death gene: 0 ;

- Diploid genome, haploid gametes;

- Probability of mutation of the gene: $0.1 \%$ per matching event.

Time passes in discrete cycles. During each cycle, every individual can change its parameters by changing its position, reproducing according to its instantaneous status (too young, at the reproductive age, already pregnant, etc.) by generating gametes that eventually undergo mutations, feeding from the neighborhood, expending its energy reserves, and dying according to intrinsic or extrinsic probabilities of death. It is important to emphasize that all the state changes are local in scope, since the new state depends on the individual's current state and on its neighborhood. The rules for changing state mimic an animal's decision-making behavior, by which we mean that animals only have access to their internal status and to information that is within the reach of their immediate senses.

\section{RESULTS}

The simulated environment has several main ingredients to mimic natural selection: individuals are born, they reproduce with mutations, and they die consistent with a given probability. This probability of death features two components - a constant rate that represents all the environmental risks to which the individual is subjected and an additional probability resulting from the expression of a deleterious gene, which represents senescence in terms of increased fragility of its host.

A typical simulation starts with all diploid individuals hosting a deleterious gene that is expressed at birth (age $=0$ ). Mutations of the deleterious gene occur randomly. At each step of the simulation, the competition between lineages of genes favors the lineage that is accompanied by fewer disadvantages. Our simulation shows the displacement of the average age of manifestation of the deleterious gene from 0 to a plateau near the age of 250 cycles in this example (Figure 3). This behavior is a consequence of the population age structure, which is discussed in the next section.

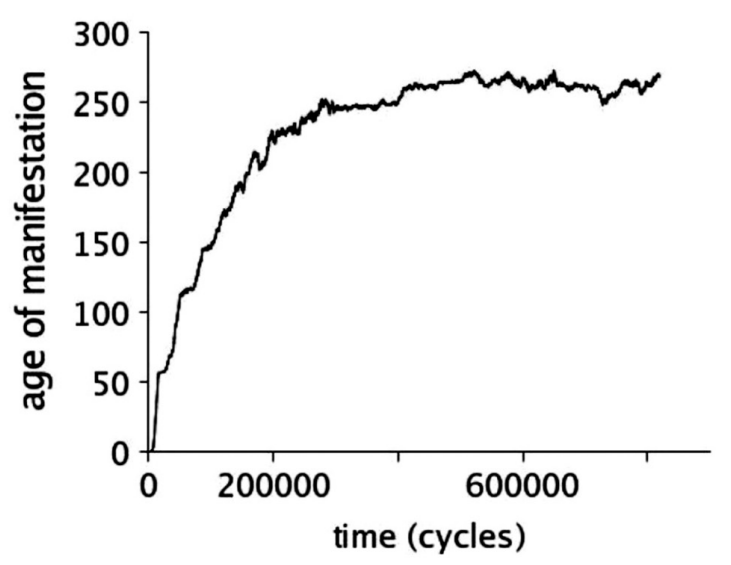

Figure 3 - Typical evolution of the average age of expression of a deleterious gene as a function of the number of simulation steps. At the beginning of a simulation (cycle $=0$ ) the gene expression occurs at birth $(\mathrm{age}=0)$. Over many generations, genes that express the deleterious effect later are progressively selected. This selection is initially fast, but it decreases with increasing simulation time until it reaches a plateau, which is around 250 cycles (arbitrary scale) in this example.

The age structure that emerges from the properties of our simulations (Figure 4a) is not surprising. In fact, it is comparable to the age-structure of human populations in less developed countries, such as the Afghanistan population in 2008 (Figure 4b). This distribution is also similar to wild, unprotected animal populations, in which birth rates are high, but child mortality quickly reduces the population that reaches reproductive age. 
(a)

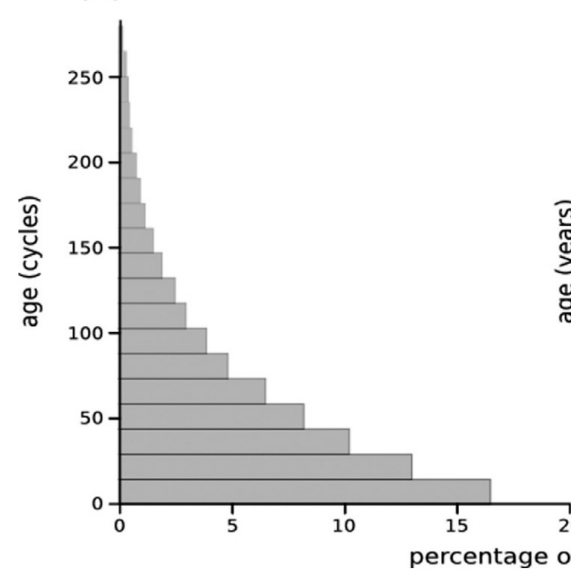

(b)

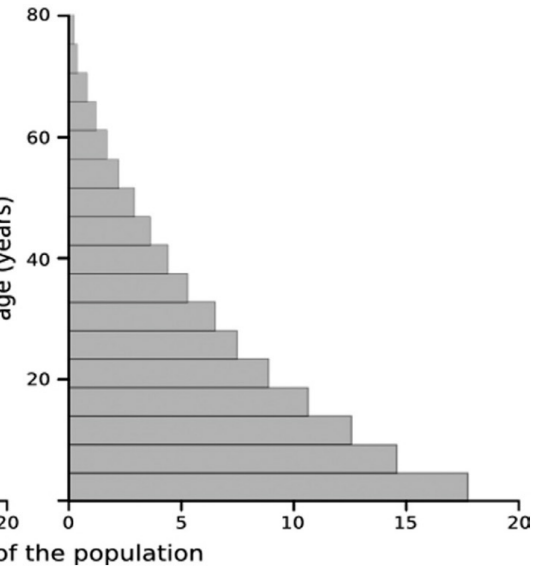

Figure 4 - Age distribution of the populations: (a) typical simulated population showing that very few individuals survive beyond 250 cycles of age, which corresponds to $87 \%$ of the maximum age (compare with figure 3); (b) age distribution of the Afghan population in 2008 showing that very few individuals survive beyond 75 years of age, which corresponds to $89 \%$ of the maximum age (data from U.S. Census Bureau, International Database, available at http:// www.census.gov/).

\section{DISCUSSION}

To try to understand senescence as being some kind of benefit would potentially be misleading. Medawar's proposal is that natural selection can be avoided by genetic strategies such as the mutation of a deleterious gene's age of expression. Under this condition, natural selection is unable to purge a deleterious gene. Instead, the expression of this gene is simply delayed to more advanced ages.

Mutated genes with delayed expression (Figure 3) are selected because the later the expression of a deleterious gene is, the smaller the removal rate of reproductive individuals from the population. Consequently, the smaller is the disturbance associated with leaving descendants to the next generation. In our simulation, very few individuals survive more than 250 cycles (Figure 4a). Thus, the facts that the selection process stops at 250 cycles and that the maximum life span is about 250 cycles are not coincidental.

We hypothesize that senescence may be the evolutionary result of many deleterious genes that are accumulated over older ages through this mechanism. This may seemingly link the aging and senility processes. In this paper, we show that this phenomenon of accumulation of deleterious genes at later ages, which is termed "mutation accumulation" in the context of Medawar's theory, can be mimicked in an artificial life system.

Although it is a simple model, postponing the manifestation of a deleterious gene to later ages through random mutation and natural selection is not the only realistic feature demonstrated by our simulation; the rate with which this delay process occurs during the simulation is not constant. The speed of selection is highest at the beginning of the simulation and is virtually null once it reaches the plateau (Figure 3). This rate decrease is a product of the decreasing force of selection, which in turn depends on the number of individuals that are alive within each age bracket. In other words, while mutations of a gene are selected in favor of more advanced ages, at which fewer individuals survive, the force of selection against the deleterious genes progressively decreases with the resulting younger population. A plateau is reached when the number of living individuals hosting the deleterious gene is so small that selection cannot confer an advantage to genes that mutate towards having a deleterious effect at even more advanced ages.

Although present in almost all superior animals and humans, senescence does not seem to be beneficial. To justify the potential benefits of senescence, two fallacious arguments are usually invoked by non-specialists: (a) that selection removes elderly individuals for the welfare of the population or (b) that senescence is an unavoidable process of organic exhaustion analogous to the deterioration of a machine. The first argument fails because the deaths of the few elderly individuals in a relatively young population release a negligible amount of resources to the rest of the population. The second argument sounds plausible but is not supported because of exceptions such as the abovementioned Blanding's turtle. Because organisms, unlike machines, can self-repair, we argue that senescence is not caused by the exhaustion of organic processes but by a programmed failure of the selfrepairing mechanisms. One may theorize about a population 
that is initially free from genes that impair the self-repairing mechanisms and is thus free of senescence. Senescence, by the mechanisms simulated here, would organically develop in a population once a new mutation introduces such a gene. Even if this gene were expressed at birth (as in the case of our simulation), natural selection would displace this gene to older ages. If many other deleterious genes can also accumulate with this mechanism, the net result will be the senile process. Blanding's turtles appear to be an exception in the sense that virtually none of these deleterious genes seem to have appeared along their evolutionary trajectory, while for most of the other species, natural selection impaired the self-repairing mechanisms by pushing deleterious genes toward advanced ages. We often consider aging and senescence as synonymous due to the temporal coincidence in their symptoms, but, in fact, we argue that they are not linked. Being aware of the distinction between aging and senescence has several implications for clinical practice.

We mentioned in the introduction that senescence, the "normal aging" feature of a population, can be described in terms of its MRDT, which is the regular time-interval at which mortality rates ordinarily double. Here we repeat the definition of senescence as a natural process, as opposed to senility, which is the effect of accumulated pathological processes upon the organism. The increase in mortality rates measured by MRDT is species-specific because it is determined by the programmed features of a given species. Senility, or "pathological aging," is characterized instead by organic limitations imposed by an individual's life history and choices, as well as its particular genetic inheritance. Such limitations are neither regular for all age brackets, nor are they speciesspecific, since they are most often associated with diseases.

For instance, creatinine clearance capacity in humans normally starts decreasing as early as the 30 s and continues to decrease, usually reaching critically low levels at ages as advanced as 100 years (Figure 5). Other organs and systems also exhibit similar spontaneous decreases, which are assumed to be a part of normal senescence. Senility, on the other hand, can be elicited by bad life habits or by lack of adherence to treatment regimens for hypertension or diabetes, both of which cause organ function to be severely compromised at ages much younger than 100 years.

It is relevant for clinical practitioners to distinguish senescence and senility when dealing with patients. The effects of natural aging are considered inexorable, and the clinician can only learn to deal with them; as to the effects of pathological aging, we are taught to prevent, treat and rehabilitate as best we can. Nevertheless, the distinction between senescence and senility, though useful, is sometimes difficult even for the experienced geriatrician. In contrast with our computational example, we still cannot understand the genetic basis of our evolution, which demonstrates why it is hard to distinguish senescence from senility.

Given this difficulty, medical history has witnessed changes in the classification of processes in the elderly from pathological to normal and vice versa, as is the case with arterial hypertension in the elderly; once thought to be a normal part of the aging process, it is now considered pathological. ${ }^{15}$

To reconcile such traditional geriatric models with the evolutionary perspective, the MRDT is helpful. Genetic features that change the MRDT are a part of a species' senescence process, while genes related to diseases may only change survival probabilities, without changing the rate of mortality doubling. ${ }^{16}$ In fact, although most genes only impact survival, a small set of genes is capable of changing the MRDT, suggesting that something in the very process of senescence can indeed be delayed. ${ }^{16}$ Such results shed light on the fuzzy boundaries between senescence and senility.

\section{CONCLUSION}

At the time of this writing, most national health promotion strategies focus on the processes of senility. If genes related to repair systems can be manipulated in the future, a second strategy may become a reality - namely, a manipulation of the processes of senescence. The expected effects of such strategies are exemplified in figure 5, which

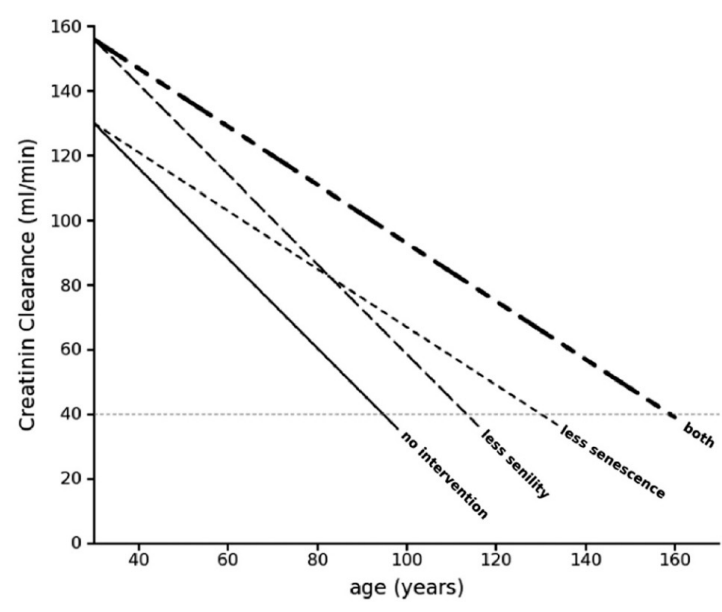

Figure 5 - Creatinine clearance decreases linearly with age. At a normal rate, departing from a normal clearance of $130 \mathrm{ml} / \mathrm{min}$, the onset of renal insufficiency is expected around the age of 95 years (solid line). A hypothetical treatment interfering with senility that could improve the initial clearance rates would shift the curve to the right, thereby postponing the onset of renal insufficiency (thick dashed line). Alternatively, if we could alter the genetic mechanisms of senescence to change the rate of loss of kidney function, the slope of the curve would change, also postponing the onset of renal insufficiency (thin dashed line). The combination of both approaches could extend renal function to much more advanced ages (thickest dashed line). 
shows that strategies against senility would change the total capability of an organ, while strategies against senescence would change the rate and character of functional loss. Although this kind of intervention is not yet a reality, physicians who are aware of these differences will be ready to recognize the role of combined strategies that may in the future become available to medical professionals.

\section{REFERENCES}

1. Hirsch HR. The waste-product theory of aging: waste dilution by cell division. Mech Ageing Dev. 1978;8:51-62.

2. Congdon JD, Nagle RD, Kinney OM, van Loben Sels RC. Hypotheses of aging in a long-lived vertebrate, Blanding's turtle (Emydoidea blandingii). Exp Gerontol. 2001;36:813-27.

3. Kirkwood TB, Austad SN. Why do we age? Nature 2000 Nov 9;408:2338.

4. Finch CE, Pike MC, Witten M. Slow mortality rate accelerations during aging in some animals approximate that of humans. Science. 1990;24;249:902-5.

5. Kirkwood TB, Cremer T. Cytogerontology since 1881: a reappraisal of August Weismann and a review of modern progress. Hum Genet. 1982;60:101-21.

6. Semsei I. On the nature of aging. Mechanisms of Ageing and development. 2000;117:93-108.

7. Gompertz B. On the nature of the function expressive of the law of human mortality and on a new mode of determining life contingencies. Philos Trans Roy Soc London. 1825;115:513-85.

8. de Magalhaes JP. Is mammalian aging genetically controlled? Biogerontology. 2003;4:119-20.
9. Medawar PB. An Unsolved Problem of Biology. 1952. London, Lewis. Ref Type: Generic

10. Williams GC. Pleiotropy, natural selection and the evolution of senescence. Evolution. 1957;11:398-411.

11. Panse Silveira PS, Massad E. Modeling and simulating morphological evolution in an artificial life environment. Comput Biomed Res. 1998;31:1-17.

12. Lenski RE, Ofria C, Pennock RT, Adami C. The evolutionary origin of complex features. Nature. 2003;8;423:139-44.

13. Chow SS, Wilke CO, Ofria C, Lenski RE, Adami C. Adaptive radiation from resource competition in digital organisms. Science. 2004;2;305846.

14. Hoffmann JP. Darwin and Computational Ecology: How Simple Models of Evolution Help our Search for Better Models of Ecological Systems. 5 A.D. Dec 6; France: Blaise Pascal University; 2005 p. 27-39.

15. Sander GE. High blood pressure in the geriatric population: treatment considerations. Am J Geriatr Cardiol. 2002;11:223-32.

16. de Magalhaes JP, Cabral JA, Magalhaes D. The influence of genes on the aging process of mice: a statistical assessment of the genetics of aging. Genetics. 2005; 169:265-74. 


\section{APÊNDICE B -- Teoria Evolutiva - \\ Conceitos úteis ao projeto}




\section{B.1 Breve histórico}

\section{B.1.0.2 Malthus e a "luta pela vida"6}

Em 1798, Thomas Robert Malthus publicou o importante Essay on the principle of population, o qual influenciaria fortemente o pensamento evolutivo. Nele, Malthus propõe seu famoso argumento de que, crescendo livremente, populações humanas tendem a aumentar de maneira exponencial, ao passo que a produção de alimentos cresce de maneira linear no mesmo tempo. Isto levaria necessariamente a uma crise na capacidade de suporte populacional de qualquer ambiente, limitando o crescimento natural das populações através da fome (Massad, 2004).

Malthus propôs, assim, o primeiro modelo matemático de crescimento populacional, o modelo exponencial. Dada uma população de tamanho inicial $N$ indivíduos, com taxas de natalidade $a$ e de mortalidade $b$ em um intervalo de tempo $t_{0}$, a taxa de crescimento líquido será dada por $r=a-b$ e a população $N^{\prime}$ após um intervalo de tempo $\Delta t$ será dada por:

$$
N^{\prime}=N r^{\Delta t}
$$

onde a taxa de crescimento $r$ é o chamado fator malthusiano.

Fica claro que o modelo malthusiano implica um crescimento populacional explosivo para um tamanho virtualmente infinito. Por outro lado, como vimos, o próprio Malthus também propôs um modelo de limitação a este crescimento, uma vez que defende o crescimento linear da produção de alimentos. Por este racional, uma população em crescimento malthusiano irá demandar, em algum momento, mais alimentos do que disponíveis. A partir deste momento, a fome determinará o limite populacional (Massad, 2004). 
O pensamento de Malthus exerceu grande influência no raciocínio evolutivo. Se populações naturais se multiplicam de maneira muito mais rápida que os recursos necessários para sua sobrevivência crescem, então todas as formas de vida tenderiam a crescer até os limites de suas possibilidades. Deste modo, todas as espécies teriam evoluído em ambientes de escassez, nos quais as menores vantagens individuais poderiam constituir a diferença entre viver ou morrer. Malthus, assim, forneceu a Darwin aquilo que este chamaria de "luta pela vida", e que constituiria a base para a formulação do processo de Seleção Natural (Rice, 2007).

\section{B.1.0.3 Evolução Darwiniana Clássica}

O fato de que a seleção artificial sobre variações espontâneas em características de plantas e animais ser capaz de produzir linhagens muito distintas das originais era fato bem conhecido por Darwin. Como este documentou, espécies na natureza também apresentavam variações espontâneas em diversas características, as quais poderiam diferenciar a capacidade de indivíduos sobreviverem e/ou se reproduzirem.

Influenciado pelo discurso de Malthus, Darwin percebeu que populações naturais tendem a gerar mais descendentes do que poderão sobreviver em um ambiente. Este, assim, exerce uma "pressão seletiva" através da qual indivíduos minimamente mais aptos a sobreviver e/ou se reproduzir deixariam mais descendentes do que outros indivíduos. Episódios sucessivos de variação e seleção natural, como Darwin denominou o fenômeno, levariam a toda a variabilidade observada na Vida. (Darwin, 1859).

Trabalhando na mesma époc que Darwin e, ao que tudo indica, sem que nenhum soubesse do trabalho do outro, Mendel realizou diversas experiências acerca 
da herança de características fenotípicas em plantas, descobrindo que esta herança acontecia de forma quantitativa, em "pacotes discretos", no que viria a constituir a base da teoria genética (Rice, 2007).

Quando o trabalho de Mendel se fez notar, este foi inicialmente tomado como uma contraprova à teoria de Darwin (Hartl; Clark, 2010). A natureza, Darwin argumentava, era um ambiente tão competitivo que as menores vantagens em adequação ao meio natural poderiam resultar em aumentos significativos na prole de seu portador; o mesmo ocorrendo sucessivamente com as variações naturais de seus descendentes, até que grandes mudanças poderiam ocorrer ao longo de muitas gerações (Darwin, 1859). As experiências de Mendel davam a impressão de variações implicavam em saltos muito abruptos nas características hereditárias e, portanto, pareciam falsificar o argumento darwiniano (Hartl; Clark, 2010).

Esta argumentação abriu um longo debate entre duas correntes de interpretação da evolução, que vieram a ser chamadas de darwinistas, que propunham variabilidade contínua de características hereditariamente determinadas, e mendelistas, proponentes da herança com variações discretas (Hartl; Clark, 2010).

\section{B.1.0.4 A moderna síntese evolutiva}

A controvérsia entre darwinistas e mendelistas durou até o início dos anos 1930, quando trabalhos de Fisher (1930), Wright (1931), e Haldane (1932) explicaram não haver contradição entre as teorias darwiniana e mendeliana (Rice, 2007). Ao contrário, a associação entre as duas teorias se tornou a base do pensamento evolutivo moderno, conhecida como a moderna síntese evolutiva (Charlesworth, 2009).

O que se segue é uma breve revisão sobre aspectos teóricos da teoria evolutiva que serão explorados neste trabalho. 


\section{B.1.1 Seleção natural}

O processo através do qual a evolução produz adaptações é denominado seleção natural. Através desta, características hereditárias com efeitos positivos sobre a sobrevivência ou reprodução de seus portadores tornam-se mais comuns em uma população (Rice, 2007).

A formulação modernamente aceita do mecanismo de seleção natural baseiase no silogismo (Hartl; Clark, 2010):

1. Em todas as espécies, mais descendentes são produzidos do que podem possivelmente sobreviver e se reproduzir;

2. Os organismos diferem na sua habilidade de sobreviver e se reproduzir em parte em virtude das diferenças no genótipo;

3. Em cada geração, os genótipos que promovem a sobrevivência no ambiente atual estão presentes em excesso na idade reprodutiva e assim contribuem desproporcionadamente para os descendentes da próxima geração.

O surgimento de adaptações tende a ocorrer diante de "pressões seletivas" sobre a variabilidade genética natural de uma população. Pressões seletivas podem ser entendidas como limitações para o desempenho de indivíduos na reprodução ou na sobrevivência em um determinado ambiente. Uma vez mantida uma pressão seletiva, sucessivas gerações poderão exibir grandes desvios na frequência genética em relação à população original. Este processo iterativo é capaz de produzir progressiva melhora do desempenho médio desta população ao longo da evolução (Hartl; Clark, 2010).

Assim, por meio da seleção natural, os alelos que aumentam a reprodução (e a sobrevivência, na medida em que esta resulte em maior reprodução) dos indivíduos portadores aumentam gradualmente de frequência na população a cada geração. Por isto, a população se torna progressivamente mais apta a sobreviver e se reproduzir 
no ambiente em que a seleção opera. A melhoria genética progressiva em populações submetidas prolongadamente a uma pressão seletiva constitui o processo de adaptação evolutiva (Rice, 2007).

Finalmente, vale mencionar que, à medida em que outros mecanismos evolutivos, tais como mecanismos da deriva genética aleatória ou de mutação do DNA têm sido descobertos e associados ao conhecimento em evolução, o termo moderna síntese evolutiva passou a denotar o estado da arte em teoria evolutiva, e não unicamente a associação entre seleção darwiniana e herança mendeliana, como inicialmente empregado.

\section{B.1.1.1 Como se mede a aptidão ?}

Quando pensamos em evolução, frequentemente evocamos a "sobrevivência do mais apto", uma tradução da frase survival of the fittest, cunhada pelo sociólogo britânico Herbert Spencer em 1864 o ler a primeira edição da Origem das Espécies, de Darwin. O próprio Darwin utilizou esta expressão nas edições subsequentes de seu livro, de modo que a sobrevivência do mais apto se tornou associada à ideia de seleção natural: os mais aptos dentro de uma população a sobreviver e / ou se reproduzirem em um determinado ambiente deixariam mais descendentes (Darwin, 1872).

Na literatura internacional em língua inglesa, o termo fitness se tornou universal. Em português, duas traduções são utilizadas: valor adaptativo e, menos frequentemente, aptidão. O primeiro termo, valor adaptativo, apesar de ser o mais utilizado, remete diretamente à ideia de adaptação. Adaptação é um caso específico dentre todos aqueles em que diferentes valores de fitness estão em jogo. O segundo termo, aptidão, é uma tradução mais exata. Ao longo desta tese, adotarei a tradução 
aptidão.

O primeiro cientista a desenvolver matematicamente a ideia de aptidão foi Haldane (Haldane, 1924). Em sua definição clássica, a aptidão de um indivíduo é o número de descendentes que deixará. Se um indivíduo de um dado genótipo $A$ deixa 10 descendentes em idade reprodutiva, sua aptidão é 10.

Caso um indivíduo de mesmo genótipo $A$ produza um número distinto, ainda que por puro acaso, sua aptidão diferirá, independentemente de sua vantagem ou desvantagem genética. Nitidamente, a medida individual da aptidão é inconveniente. Sobre esta questão, Maynard Smith adiciona o seguinte comentário (Maynard Smith, 1997):

Aptidão é uma propriedade não de um indivíduo, mas de uma classe de indivíduos - por exemplo, homozigose para o alelo A em um locus em particular. Assim, a frase "número esperado de descendentes" significa o número médio, não o número de indivíduos produzido por um único indivíduo. Se o primeiro bebê humano com um gene para levitação fosse atingido por um raio no seu carrinho, isto não provaria que o novo genótipo tem baixa aptidão, mas apenas que a criança em particular não teve sorte.

Por esta razão, no uso moderno do termo aptidão fica implícita a menção a uma determinada categoria. $W$ é a contribuição em média para o pool genético feita por um indivíduo de um dado fenótipo. Assim a aptidão de um genótipo $A$ é definida como a razão entre o número de portadores adultos do genótipo $A$ após um episódio de seleção e antes dele, e pode expressa por:

$$
W_{A}=\frac{N_{A_{\text {depois }}}}{N_{A_{\text {antes }}}},
$$

onde $N_{A}$ é o número de indivíduos adultos do genótipo $A$, antes ou após um episódio de seleção. $W_{A}$ descreve, portanto, a habilidade média de um indivíduo com o fenótipo ligado ao genótipo $A$ em sobreviver $e$ se reproduzir. Quando $W_{a b s}>1$, 
a população de portadores de um dado genótipo está em crescimento. Embora correto, este conceito não nos diz muito: apenas se o genótipo A está em crescimento, estacionário ou caindo em números absolutos. Não sabemos o mais importante: se o genótipo $A$ está em processo de fixação, extinção ou equilíbrio (Futuyma, 1998, Chapter 12).

Se alelos de um mesmo gene determinarem distintos valores de $W_{a b s}$, então a relação entre as frequências destes alelos na população mudará ao longo das gerações. Alelos com maiores valores de aptidão se tornarão mais frequentes em relação aos outros alelos. Esta é, simplesmente, a expressão do conceito da seleção natural em termos de aptidão. Assim, a comparação dos valores de $W_{a b s}$ em alelos competidores correlaciona-se diretamente com aquilo que comumente chamamos de força de seleção: é exatamente o diferencial na aptidão de um grupo em relação a outro que leva à seleção (Haldane, 1924). Para isto, necessitamos da aptidão relativa.

A aptidão relativa $\left(W_{\text {rel }}\right)$ nos informa sobre a evolução de um determinado genótipo em relação a um genótipo competidor: suponhamos que, na mesma população acima, indivíduos de genótipo $B$ produzam em média 15 indivíduos de idade reprodutiva $\left(W_{a b s}(B)=15\right)$. Por convenção, o grupo com maior $W_{a b s}$ é o grupo de referência. Assim, a aptidão relativa de $A$ é sua aptidão absoluta em comparação com o grupo de maior aptidão absoluta na população (o qual, por esta definição, tem aptidão relativa igual a 1,0). $W_{\text {rel }}$ pode assumir qualquer valor entre 0 e 1 (Futuyma, 1998, Chapter 12).

Desta forma,

$$
W_{r e l} \frac{A}{B}=\frac{W_{a b s} A}{W_{a b s} B}
$$

onde $W_{\text {rel }} \frac{A}{B}$ é a aptidão do grupo $A$ em relação ao grupo $B$, podendo ser também expresso simplesmente $W_{\text {rel }}(A)$. No exemplo acima, $W_{\text {rel }}(A)=0,67$. 
Os dois conceitos de aptidão são correlacionados; seus valores se tornam numericamente equivalentes quando divididos pelo equivalente médio da população, que é uma média dos valores de aptidão para cada variante ponderada para as diferentes frequências populacionais de seus portadores:

$$
\frac{W_{a b s}}{\overline{\bar{W}}_{a b s}}=\frac{W_{r e l}}{\bar{W}_{r e l}} .
$$

Interessante notar que a aptidão relativa média, $\bar{W}_{\text {rel }}$, é equivalente à aptidão média dos indivíduos em uma população em relação ao grupo com maior aptidão na mesma população.

\section{B.1.1.2 Seleção em haplóides em gerações discretas}

Retomando a ideia acima (seção B.1.1), a seleção atua no fenótipo e este é correlacionado ao genótipo; assim, a seleção de um fenótipo levará ao aumento da frequência do(s) gene(s) associado(s) a este fenótipo. A situação mais simples de seleção é aquela operada em um organismo haplóide assexual (como as espécies de bactérias).

A título de exemplo, podemos assumir um modelo de crescimento populacional discreto em que dois genótipos bacterianos $A$ e $B$ se reproduzem assexuadamente em um mesmo meio, com taxas de crescimento $a$ e $b$ respectivamente. Em um modelo discreto de crescimento populacional geométrico, se $A_{0}$ e $B_{0}$ forem o número de células bacterianas no tempo 0 , o números $A_{t}$ e $B_{t}$ de células bacterianas no tempo $t$ serão dados respectivamente por $A_{t}=(1+A)^{t} A_{0}$ e $B_{t}=(1+B)^{t} B_{0}$. Podemos esperar que ocorra seleção sempre que $a \neq b$, independente do número real de indivíduos na população (Hartl; Clark, 2010, Capítulo 5). 
Por este motivo, para estudar como acontece seleção, é útil considerar a proporção de indivíduos bacterianos $A$ em relação aos indivíduos $B$ e de que forma esta razão evolui com o tempo $t$. tal razão $\frac{A_{t}}{B_{t}}$ é dada por (Hartl; Clark, 2010, Capítulo 5):

$$
\frac{A_{t}}{B_{t}}=\left(\frac{1+a}{1+b}\right)^{t} \frac{A_{0}}{B_{0}}=\left(W_{\text {rel }} \frac{A}{B}\right)^{t}\left(\frac{A_{0}}{B_{0}}\right) .
$$

Se $a>b$, a razão $\frac{A}{B}$ aumentará até que a população $B$ tenha sido perdida; para $a<b$, sucederá o contrário. Quando consideramos o crescimento da população, como no exemplo atual, não é necessário especificar se $a \neq b$ por motivos de capacidade de sobrevivência ou por fertilidade, ou por ambas. O que importa é que, se $a \neq b$, as espécies $A$ e $B$ diferem em sua aptidão ao meio que estamos considerando; em virtude disto, estão crescendo em velocidades diferentes.

Por isto, não necessitamos conhecer as taxas absolutas de crescimento de $A$ e $B$ : o resultado da seleção em termos de variações na proporção dos indivíduos de espécie $A$ ou $B$ dependerá somente da razão $\frac{1+a}{1+b}$. Na Equação B.5, esta razão representa a aptidão entre genótipos $A$ e $B$ que, como vimos, é representada por $W_{\text {rel }} \frac{A}{B}$.

Também não necessitamos saber o tamanho absoluto da população. Para saber o resultado da seleção, basta conhecermos as frequências iniciais $p_{0}$ e $q_{0}$ das duas populações e a aptidão relativa $W_{\text {rel }}$ entre elas. Assim, o resultado da seleção após $t$ gerações discretas será expresso pela razão $\frac{p_{t}}{q_{t}}$, que é a frequência da população $A$ em relação à frequência da população $B$ no tempo $t$; partindo do tempo 0 , esta transformação é dada por

$$
\frac{p_{t}}{q_{t}}=\left(W_{r e l} \frac{A}{B}\right)^{t} \frac{p_{0}}{q_{0}} .
$$




\section{B.1.1.3 Seleção em haplóides em gerações contínuas}

Populações bacterianas reais, diferentemente do que idealizamos acima, reproduzemse de forma contínua. Assim, o crescimento exponencial das populações $A$ e $B$ do tempo 0 ao tempo $t$, com taxas de crescimento $a$ e $b$, é dado respectivamente por $A_{t}=A_{0} e^{a t}$ e $B_{t}=B_{0} e^{b t}$. O resultado da seleção é expresso por

$$
\frac{A+t}{B_{t}}=\frac{A_{0}}{B_{0}} e^{(a-b) t}=\frac{A_{0}}{B_{0}} e^{m t},
$$

onde $m=a-b=$ aptidão relativa para o crescimento contínuo (Hartl; Clark, 2010, Capítulo 5).

Comparando as Equações B.5 e B.7, podemos relacionar $W_{\text {rel }}$ e $m$ :

$$
m=\ln \left(W_{\text {rel }}\right) .
$$

Iniciamos a Seção B.1.1.2 dizendo que para haver seleção, basta que $a \neq b$; a situação inversa, em que $a=b$, portanto, não admite seleção. Tal situação é chamada de neutralidade seletiva; haverá, portanto, neutralidade seletiva sempre que $W_{\text {rel }}=1$ ou $m=0$.

\section{B.1.2 Evolução e Adaptação}

Evolução em biologia é o "processo pelo qual acontecem mudanças nas frequências genéticas em populações de organismos com o passar do tempo" (Rice, 2007, pág 150).

Evolução no sentido leigo poderia denotar o processo de transição de uma forma física para outra (estrelas evoluem) ou mesmo ter uma conotação de progresso (como em evolução do conhecimento humano). Esta última é, aliás, uma conotação 
corrente e errada quando se pensa na teoria evolutiva, permeada pelo que Dawkings chama o problema do hindsight e pelo apelo adaptacionista ao senso comum e a muitos cientistas (Dawkings, 2005).

O problema do hindsight relaciona-se à "percepção da natureza de um evento após este ter acontecido"1. Como Dawkins nota, isto é o que se faz quando se afirma que somos mais evoluídos que nossos ancestrais (Dawkings, 2005).

\section{werefertik}

Figura B.1 - O famoso diagrama da evolução humana e a falácia do hindsight. Esta imagem, provavelmente conhecida de qualquer leitor culto, não deve ser interpretada como sugestão de que evolução implica em propósito ou necessariamente progresso.

Nós sabemos que descendentes do Australopithecus afarensis dariam origem ao homem moderno. A evolução não "sabe" nada. Não há processo cognitivo ou envolvimento de um design inteligente na evolução. A evolução não tem propósito, não tem direção programada, não prevê soluções, não atua no futuro (Dawkings, 2005).

As formas de vida fazem ou não fazem sentido a cada momento, em cada situação específica. Como não vivemos no mesmo ambiente de seleção em que viveram os australopitecos, não faz sentido acreditar que somos mais evoluídos. Cada uma das espécies do mundo "respondem" aos ambientes evolutivos em que se inserem e podem ser, cada uma delas, perfeitamente evoluídas. Por isto é incorreto dizer que somos mais evoluídos do que um tubarão, apesar de todas as diferenças anatômicas

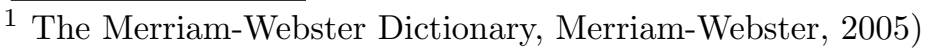


e fisiológicas. Talvez simplesmente não tenha havido força seletiva no sentido de que os tubarões mudassem tanto quanto nossos ancestrais e, portanto, estes se mantiveram sem tantas transformações, tão evoluídos quanto sempre foram. Ainda assim, os processos evolutivos deram origem à vida como conhecemos. Acredito que esta é em grande parte, a "grandeza nesta visão da vida" aludida por Darwin ao concluir A Origem das Espécies (Darwin, 1859).

O segundo problema é o apelo adaptacionista, que leva tanto à classificação de eventos não-adaptativos como adaptações quanto à sobrevalorização do papel da adaptação na evolução (Dawkings, 2005; Futuyma, 1998; Rice, 2007). Em termos leigos, o termo adaptação tem sido utilizado para referência a 8 processos distintos. Destes, 4 processos não são sequer processos evolutivos (Tabela B.1a), pois não envolvem diretamente a mudança na frequência genética de uma população; dos 4 processos evolutivos exemplificados (Tabela B.1b), apenas um pode ser chamado de adaptação: é o processo em que a seleção natural exerce uma pressão sobre uma população em que variações genéticas causadas por mutaçôes condicionam diferentes valores de aptidão em seus portadores, fazendo com que, através de inúmeras gerações, surjam grandes modificações na genética destas populações. Estas modificações, que aumentam as probabilidades de sobrevivência de seus portadores, também são chamadas de adaptações (Rice, 2007).

\section{B.1.3 A Deriva genética aleatória e a Teoria Neutra da Evo- lução}

Mutações que não conferem nenhuma vantagem ou desvantagem são ditas seletivamente neutras. Isto também vale para mutações sobre genes que conferem vantagens ou desempenham função primordial em um organismo: um alelo mutante 
(a) Processos não evolutivos

\begin{tabular}{ll}
\hline Processo & Descrição \\
\hline Ambientais & Efeitos diretos e transitórios do ambiente na fisiologia \\
Fisiológicos & Resposta fisiológica do organismo sobre um estímulo ambiental \\
Aclimação & Mudanças na expressão gênica induzidas pelo ambiente \\
Plasticidade & Variações no desenvolvimento induzidas pelo ambiente \\
\hline & \multicolumn{1}{c}{ (b) Processos evolutivos } \\
\hline Processo & Descrição \\
\hline Deriva genética & Mudanças aleatórias na frequência gênica (sem seleção) \\
Contingência & Acidentes históricos, catástrofes, migração, etc. \\
Exaptação & Efeito colateral de seleção por outra característica \\
Adaptação & Seleção natural agindo diretamente sobre uma característica \\
\hline
\end{tabular}

Tabela B.1 - Exemplos de processos frequentemente chamados de Adaptação. Adaptado de Rice (2007)

deste gene que não confira nenhuma vantagem adicional sobre o gene original é uma mutação seletivamente neutra deste gene.

Por definição, mutações seletivamente neutras não estão sujeitas a pressões seletivas. No entanto, as frequências de diferentes alelos de um gene tendem a variar com o tempo. Isto acontece por mero acaso: a cada geração, estes alelos estão sujeitos a repetidas amostragens aleatórias. Como resultado, as frequências alélicas flutuam ao longo das gerações de uma população, podendo inclusive evoluir para fixação ou extinção de um determinado alelo (Figura B.2). A este processo de evolução não adaptativa denomina-se deriva genética aleatória.

Alguns dos aspectos fundamentais do mecanismo de evolução sob deriva genética incluem (Futuyma, 1998, Capítulo 10):

1. As frequências de diferentes alelos ou haplotipos flutuam aleatoriamente nas populações ao longo das gerações; finalmente, um ou outro destes alelos se tornará fixo; 


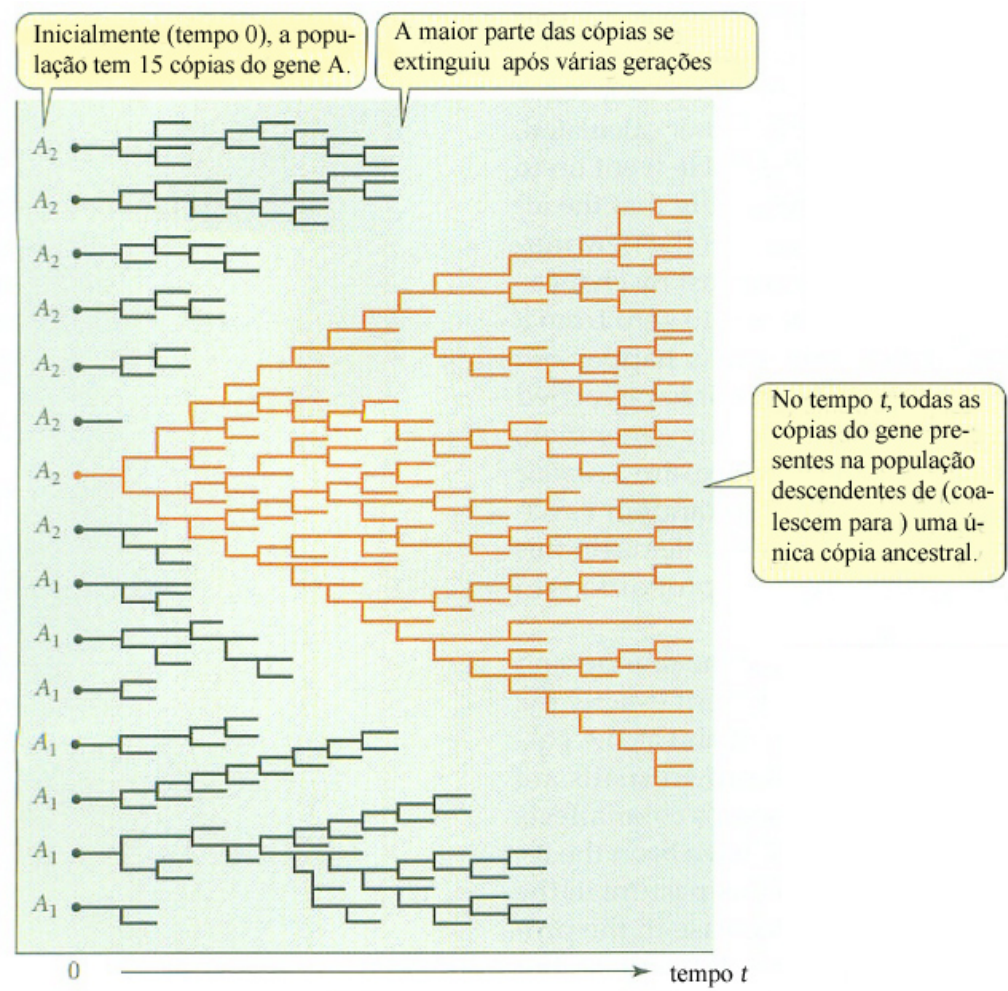

Figura B.2 - Evolução com fixação por deriva genética aleatória. Extraído de Futuyma (1998).

2. Por esta razão, a variabilidade genética em um dado locus tende a diminuir com o tempo e finalmente, perder-se;

3. Em organismos diplóides, à medida em que a frequência de um alelo cai, a frequência de indivíduos heterozigotos também o faz; por isto, a taxa de declínio de heterozigosidade é uma medida da taxa de deriva genética em uma população;

4. Em um momento qualquer, a probabilidade de um alelo se fixar por deriva genética equivale à sua frequência $(p)$ na população naquele momento; tal probabilidade não é influenciada pelas oscilações prévias na frequência deste mesmo alelo;

5. Populações com a mesma frequência alélica $p$ divergem com o tempo (Fi- 
gura B.3), e espera-se que uma proporção $p$ das populações se torne fixa para o alelo;

6. Em uma população de tamanho $N$, uma mutação nova de um alelo possui frequência $p=\frac{1}{N}$; portanto, a probabilidade de fixação de uma mutação nova por deriva é inversamente proporcional ao tamanho populacional;

7. Caso um alelo neutro seja fixado por deriva, o tempo médio esperado para fixação é de $2 N$ gerações em populações haplóides e $4 N$ gerações para populações diplóides; a evolução por deriva genética é, portanto, consideravelmente mais rápida em populações menores (comparem-se na Figura B.3 os gráficos (a) e (b)).

Como se depreende dos trabalhos clássicos de Fisher e Writght, a deriva genética foi inicialmente considerada um processo de importância evolutiva menor (Fisher, 1930; Wright, 1931). No entanto, o sequenciamento de proteínas a partir da década de 1960 deixou claro que a diversidade genética era muito maior do que se esperava possível sob ação preponderante da seleção natural (Kimura; Crow, 1964).

Isto levou Mooto Kimura a minimizar a importância da seleção natural como a grande força motora da evolução. Diante disto, Kimura propôs que a maior parte da variabilidade geneticamente condicionada fosse seletivamente neutra. Como tal, não poderia ter sido fixada por seleção natural, mas por deriva genética (Kimura, 1968).

A partir desta proposição inicial, Kimura e outros propositores da Teoria Neutra da Evolução defenderam um papel preponderante da deriva genética na evolução de populações (Futuyma, 1998, Capítulo 10). Isto implica em dizer que grande parte da diversidade genética é um fenômeno transitório: mutações neutras são alea- 

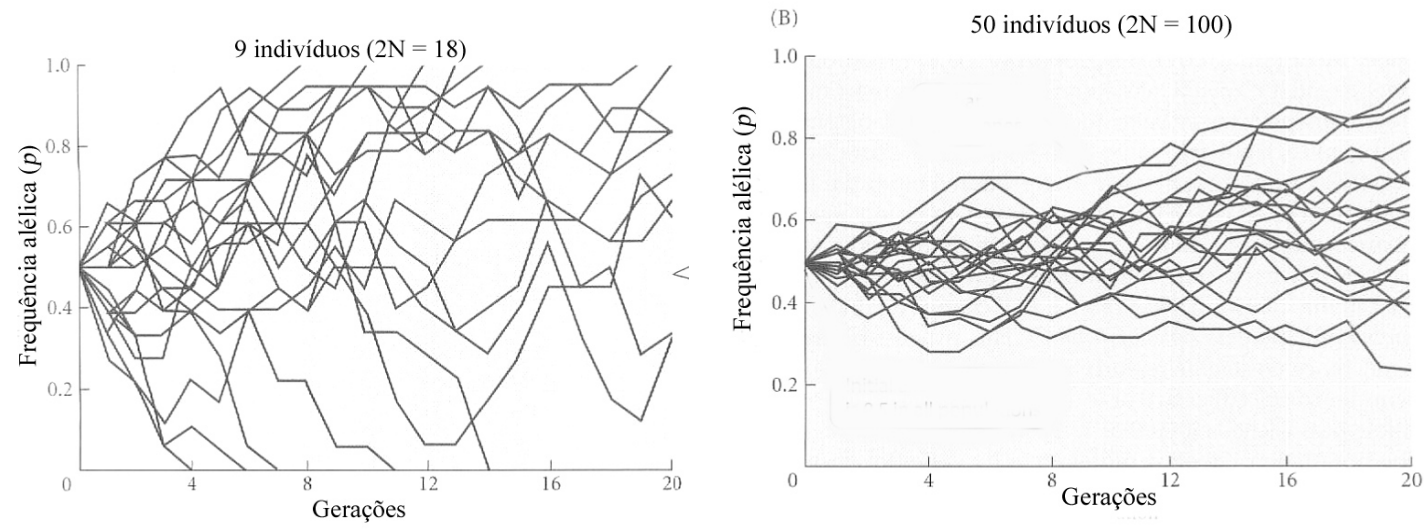

Figura B.3 - Variação na frequência alélica por deriva genética aleatória em 2 tamanhos populacionais por simulação computacional. A variabilidade é nitidamente maior na Figura B.3a, em que alguns alelos se fixaram e outros foram perdidos ao longo da simulação. Extraído de Futuyma (1998).

toriamente introduzidas no pool genético e podem se tornar fixas ou completamente perdidas, exclusivamente devido a forças estocásticas.

A contribuição relativa da seleção e da deriva genética aleatória para a manutenção da variabilidade oriunda de mutações é ainda tema de grande debate no meio acadêmico (Futuyma, 1998, Capítulo 10). O que não deixa margens à dúvida, no entanto, é que o papel da deriva genética aleatória é maior do que se pensava quando as teorias evolutivas da senescência foram formuladas.

\section{B.1.3.1 O Modelo Populacional de Wright-Fisher}

Chama-se Modelo de Wright-Fisher (MWF) o modelo idealizado de uma população cujos membros podem se encontrar e acasalar com quaisquer outros membros do outro gênero, a relação machos / fêmeas é de 1, todos os membros de uma geração são adultos reprodutores e não existe sobreposição de gerações (gerações discretas). Isto significa que todos os membros da população, na ausência de seleção, têm a mesma probabilidade de contribuir com material genético para a próxima geração. O modelo também implica em que a cada geração a população inteira se 
renova, havendo uma única oportunidade reprodutiva. Além disto, o tamanho da população mantém-se fixo ao longo das gerações.

Podemos descrever sucintamente o MWF da seguinte forma: suponhamos que uma população diplóide de tamanho $N$ indivíduos sexualmente maduros e reprodutivos (ou, o que é o mesmo neste caso, uma população haplóide de tamanho $2 N$ ), com acasalamento aleatório e gerações discretas. A cada geração, $2 N$ gametas são amostrados aleatoriamente a partir da geração parental. Se $Y_{(n)}$ denota o número de gametas do tipo $A 1$ na geração $n$, então, na ausência de mutação e seleção, o número de alelos $A 1$ no tempo $n+1$ é dado por uma distribuição binomial. Ou seja, a probabilidade de existirem $j$ gametas do tipo $A 1$ na geração de $n+1$, dado que havia $i$ gametas do tipo $A 1$ na geração $n$, é dada pela Equação B.9 (Hartl; Clark, 2010).

$$
P\left(Y_{(n+1)}=j \mid Y_{(n)}=i\right)=\left(\begin{array}{c}
2 N \\
j
\end{array}\right)\left(\frac{i}{2 N}\right)^{j}\left(1-\frac{i}{2 N}\right)^{2 N-j}
$$

Se seguirmos uma população que evolui de acordo com o modelo definido na equação B.9, observaremos que seu comportamento é altamente imprevisível, devido à natureza estocástica do modelo (Hartl; Clark, 2010). Isto significa que populações inicialmente iguais e com suas distribuições alélicas seguindo a dinâmica da Equação B.9 seguirão trajetórias distintas ao longo do tempo. A equação B.9 também mostra que, embora o número de gametas presentes na população a cada geração varie de forma aleatória, o tamanho populacional influencia no processo. De fato, na equação B.9, para maiores valores de $N$, menor será o efeito aleatório na determinação do número de gametas $A 1$ nas gerações subsequentes.

O Modelo de Wright-Fisher se tornou uma referência para estudos de genética populacional, incluindo simulações matemáticas e computacionais. Do modelo original, adaptações incluíram as implicações de várias outras estruturas popula- 
cionais e arquiteturas genéticas. Assim, podemos falar em MWF com gerações contínuas, MWF com populações haplóides, etc (Charlesworth, 1980). Como tais derivações do modelo original têm sido extensamente estudadas, as equações aplicáveis para cada derivação em geral já estão disponíveis e validadas (Charlesworth, 2009). Assim, se um pesquisador diz que usou um Modelo de Wright-Fisher assexuado e haplóide, sabemos exatamente a que esta definição de população se refere, bastando entender que, do modelo original, a população de estudo apenas difere por ser haplóide e assexuada.

\section{B.1.4 Tamanho populacional efetivo $\left(N_{e}\right)$}

A Equação B.9 vale apenas para populações que preencham todos os critérios do modelo clássico de Wright-Fisher: uma população diplóide de acasalamento aleatório e sem sobreposição de gerações. Trata-se nitidamente, de uma população idealizada. Populações de mesmo tamanho, cujas características se desviem das características mencionadas, estarão mais sujeitas aos efeitos da deriva genética. Quanto mais distinta do MWF uma população for, maior será o efeito da deriva genética (Hartl; Clark, 2010).

O conceito de tamanho populacional efetivo começou a ser estudado a partir de dois artigos clássicos de Sewall Wright (Wright, 1931, 1938). Define-se o $N_{e}$ de uma população como sendo o número de indivíduos adultos de uma população idealizada segundo o modelo clássico de Wright-Fisher em que se esperaria exatamente a mesma magnitude de deriva exibida na população real de tamanho $N$ (Hartl; Clark, 2010, Capítulo 3).

Independentemente do quanto uma população se afaste do MWF, uma vez que saibamos o valor de seu $N_{e}$, podemos utilizá-lo, por exemplo, no lugar de $N$ na 
equação B.9, pois agora as diferenças em relação ao MWF já estão contabilizadas. A probabilidade de existirem $j$ gametas do tipo $A 1$ na geração de $n+1$, dado que havia $i$ gametas do tipo $A 1$ nesta população será, da mesma forma:

$$
P\left(Y_{(n+1)}=j \mid Y_{(n)}=i\right)=\left(\begin{array}{c}
2 N_{e} \\
j
\end{array}\right)\left(\frac{i}{2 N_{e}}\right)^{j}\left(1-\frac{i}{2 N_{e}}\right)^{2 N_{e}-j} .
$$

Atualmente, na criação de modelos para o estudo de genética de populações é fundamental a consideração sobre o tamanho populacional efetivo. Podemos definir $N_{e}$ de três maneiras, de acordo como medimos $N_{e}$ : tamanho efetivo de endocruzamento (medido pela mudança na probabilidade de identidade por descendência), tamanho efetivo de variância (medido pela mudança na variância das frequências alélicas) e tamanho efetivo de de autovalor (medido pela taxa de perda de heterozigosidade). Concentrar-me-ei no tamanho efetivo de endocruzamento, porque é o conceito mais amplamente usado em literatura (Hartl; Clark, 2010, Capítulo 3).

\section{B.1.4.1 Variações no tamanho populacional $(N)$}

O tamanho populacional pode variar com o tempo, seja por aumentar além da média histórica por aumento temporário em recursos (alimento, água, etc.), seja por diminuir em situações de carência transitória destes mesmos recursos.

Supondo-se uma população simplificada sem superposição de gerações (indivíduos vivem durante uma única geração) o tamanho populacional efetivo é aproximadamente dado pela média harmônica do tamanho das populações em cada geração, ou seja, o inverso da média dos inversos:

$$
\frac{1}{N_{e}}=\frac{1}{t}\left(\frac{1}{N_{1}}+\frac{1}{N_{2}}+\ldots+\frac{1}{N_{t}}\right)
$$


que pode ser escrito de forma mais geral como

$$
\frac{1}{N_{e}}=\frac{1}{t} \sum_{i=1}^{t} \frac{1}{N_{i}}
$$

onde $N_{t}$ é o tamanho populacional real na geração de número $t$ e $i$ é cada geração sucessivo, numerada em ordem, de 0 a $t$.

Como $N_{e}$ é definido pela média harmônica dos tamanhos populacionais, $N_{e}$ é dominado pelos menores valores assumidos pelo tamanho populacional. Suponhamos a título de exemplo que em 5 gerações $(t=5)$, o tamanho populacional foi de $N=$ $100 ; 10 ; 500 ; 20 ; 800$.

O tamanho populacional efetivo será a média harmônica destes 5 termos, ou seja:

$$
\frac{1}{N_{e}}=\frac{\frac{1}{100}+\frac{1}{10}+\frac{1}{500}+\frac{1}{20}+\frac{1}{800}}{5}=\frac{0,16325}{5}=0,03265 \therefore N e=30,63 .
$$

Notamos que $N_{e}$ é muito menor do que a média aritmética dos tamanhos das populações, que seria 286.

Esta noção é de particular importância para o chamado "efeito gargalo", que ocorre quando uma população é submetida a a uma redução muito importante no número de integrantes a a seguir se recupera e expande. O efeito da deriva se torna tão importante que a perda de variabilidade genética e de heterozigosidade podem perdurar por milhares de gerações.

\section{B.1.4.2 Gerações contínuas e estrutura etária}

Quando indivíduos em uma população vivem mais do que um período reprodutivo, $N_{e}$ deve levar em conta as tábuas de mortalidade para a espécie em 
questão (Felsenstein, 1971).

Podemos definir a título de exemplo uma população haplóide com estrutura etária discreta (idade evolui em intervalos de tempo discretos), cujos integrantes podem sobreviver por diversos períodos reprodutivos. Definamos também algumas características desta população:

$v_{i}=$ Valor reprodutivo de Fisher na idade $i$,

$\ell_{i}=$ A probabilidade de um indivíduo sobreviver da idade 0 até a idade $i$ e

$N_{0}=$ O número de indivíduos nascidos a cada unidade de tempo.

A duração média de uma geração é calculado como:

$$
T=\sum_{i=0}^{\infty} \ell_{i} v_{i}
$$

que é a idade média do indivíduo ao reproduzir-se.

Finalmente, o tamanho populacional efetivo (Felsenstein, 1971) é dado por

$$
N_{e}^{(F)}=\frac{N_{0} T}{1+\sum_{i} \ell_{i+1}^{2} v_{i+1}^{2}\left(\frac{1}{\ell_{i+1}}-\frac{1}{\ell_{i}}\right)} .
$$

Em populações com estrutura etária, portanto, $N_{e}$ tende a ser menor do que o tamanho real da população. Este é um conceito importante para entendermos a evolução da senescência, pois, como veremos, a estruturação etária é a base das teorias sobre a evolução da senescência.

\section{B.1.5 O Modelo de Alelos Infinitos}

O modelo de alelos infinitos é um modelo matemático para estimativa de mutações genéticas. Os geneticistas Motoo Kimura e James F. Crow introduziram o modelo de alelos infinitos numa tentativa de determinar, para uma população diplóide de tamanho finito, qual a proporção de loci que se manteriam em homozigose. 
Seu trabalho foi motivado pelas afirmações de outros geneticistas de que mais de $50 \%$ dos loci em Drosophila seriam heterozigotos, do que inicialmente duvidaram. Para responder a esta pergunta, Kimura e Crow inicialmente assumiram que havia um número suficiente de alelos para que qualquer mutação levasse a um alelo diferente (ou seja, que a probabilidade de mutação de volta para o mesmo alelo original seria baixa o suficiente para ser desprezível); e segundo, que as mutações resultariam em alelos com diferentes impactos em aptidão, desde neutros até francamente deletérios.

A seguir, determinaram que, em casos neutros, a probabilidade $F$ de que um indivíduo fosse homozigoto para o alelo seria:

$$
F=\frac{1}{4 N_{e} \lambda+1},
$$

onde $\lambda$ é a taxa de mutação e $N_{e}$ é o tamanho populacional efetivo. O número $n$ de alelos mantidos em uma população foi definido como o inverso da homozigozidade, ou seja:

$$
n=\frac{1}{F}=4 N_{e} \lambda+1,
$$

que representaria o limite inferior para o número real de alelos presentes na população.

Se $N_{e}$ for grande, um grande número de alelos poderá ser mantido. Deve ser enfatizado que isto vale para os casos neutros, não sendo uma conclusão diretamente válida para situações em que existam diferenças em entre os alelos, principalmente nas situações em que os indivíduos heterozigotos possuem os maiores valores de (Kimura; Crow, 1964). 


\section{B.1.6 Equilíbrio Seleção - Mutação}

A existência de um influxo de novos alelos via mutação espontânea exerce uma pressão pela variabilidade genética. Na ausência de qualquer pressão seletiva (no caso de mutações neutras, por exemplo), esperaríamos um aumento do número de alelos variantes em uma população, cuja distribuição alélica seria determinada apenas pelo equilíbrio entre mutação e deriva.

No entanto, mutações benéficas ou deletérias (aumentam ou diminuem o de seu portador) estão sujeitas à força de seleção. Intuitivamente esperamos que mutações deletérias desapareçam do pool genético de uma população e que mutações benéficas substituam os alelos originais da população. No entanto, a possibilidade de mutações deletérias recorrentes (surgindo de novo a cada geração a partir de outros alelos) exerce uma pressão pela manutenção de uma característica deletéria no pool genético. Assim, uma característica deletéria sob mutação recorrente não será eliminada por seleção: sua frequência entrará em equilíbrio quando a capacidade de eliminação por seleção se tornar equivalente, a cada geração, à sua reintrodução por mutações recorrentes.

A frequência de equilíbrio $f$ de um gene é expressa, em haplóides (ou em diplóides no caso de um gene dominante), por:

$$
f=\frac{\lambda}{W}
$$

e, de um gene recessivo em diplóides, por:

$$
f=\sqrt{\frac{\lambda}{W}}
$$

onde $\lambda$ é a taxa de ocorrência de novas mutações e $W$ é o coeficiente seletivo do efeito deletério em questão. 


\section{B.1.7 O efeito conjunto de Seleção e Deriva}

Em populações reais, entende-se que mecanismos de seleção operam em conjunto com mecanismos de deriva genética aleatória, isto porque populações reais dificilmente são grandes o suficiente para que o efeito da deriva possa ser desprezado. Sabendo-se, por exemplo, que a probabilidade de fixação de um alelo neutro por deriva é, em haplóides, de $\frac{1}{2 N_{e}}$ (Hartl; Clark, 2010), em uma população com $N_{e}=50$, uma nova mutação neutra se tornará fixa, ou seja, reporá todos os outros alelos variantes com uma probabilidade não desprezível de $\frac{1}{100}$.

Por outro lado, uma mutação que não seja neutra estará sujeita à seleção $e$ deriva ao mesmo tempo. A intensidade relativa de cada mecanismo sobre as modificações nas frequências deste alelo dependerá do coeficiente seletivo de um alelo e do tamanho populacional efetivo.

Dentro deste caso, podemos conceber uma situação especial em que mutações fracamente deletérias (chamadas de mutações quase neutras) recorrem em populações pequenas. Neste tipo especial de cenário evolutivo, a seleção contra tais alelos será, por definição, muito fraca. Ao mesmo tempo, os efeitos da deriva genética, inversamente proporcionais ao tamanho da população, serão consideráveis. Neste cenário sob efeito conjunto de seleção e deriva, mutações deletérias podem manterse flutuando significativamente acima da frequência de equilíbrio seleção-mutação. Podem também evoluir para fixação, apesar de desfavorecidas pela seleção. 


\section{Referências}

Abrams PA. Does increased mortality favor the evolution of more rapid senescence. Evolution. 1993, 47(3), 877-887.

Ameisen JC. Looking for death at the core of life in the light of evolution. Cell Death Differ. 2004, 11(1), 4-10.

Ameisen JC. [selective "death programs"or pleiotropic "life programs"? looking for programmed cell death in the light of evolution]. J Soc Biol. 2005, 199(3), 175-89.

Arias E. United states life tables, 2003. National Vital Statistics Reports. 2006, $54(14)$.

Austad SN. Retarded senescence in an insular population of virginia opossums (didelphis virginiana). Journal of Zoology. 1993, 229(4), 695-708.

Austad SN. Comparative aging and life histories in mammals. Exp Gerontol. 1997, $32(1-2), 23-38$.

Austad SN. Why we age. New York: John Wiley and Sons, Inc, 1997.

Austad SN. Does caloric restriction in the laboratory simply prevent overfeeding and return house mice to their natural level of food intake? Sci Aging Knowledge Environ. 2001, 2001(6), pe3.

Austad SN, Kristan DM. Are mice calorically restricted in nature? Aging Cell. 2003, 2(4), 201-7.

Baret P, Lints FA. Selection for increased longevity in drosophila melanogaster: a new interpretation. Gerontology. 1993, 39(5), 252-9.

Beemer JK, Anderton DL, Leonard SH. Sewers in the city: a case study of individual-level mortality and public health initiatives in northampton, massachusetts, at the turn of the century. J Hist Med Allied Sci. 2005, 60(1), 42-72.

Bidder GP. Senescence. Br Med J. 1932, 2(3742), 583-585.

Bronikowski AM et al. The aging baboon: comparative demography in a non-human primate. Proc Natl Acad Sci U S A. 2002, 99(14), 9591-5. 
Broussard DR et al. Senescence and age-related reproduction of female columbian ground squirrels. Journal of Animal Ecology. 2003, 72(2), 212-219.

Bufill E, Blesa R. [Alzheimer's disease and brain evolution: is alzheimer's disease an example of antagonistic pleiotropy?]. Rev Neurol. 2006, 42(1), 25-33.

Busse EW. Theories of aging. In: Busse EW, Pfeiffer E (Ed.). Behavior and adaptation in late life. Boston: Little Brown, 1969.

Cailliet GM et al. Age determination and validation studies of marine fishes: do deep-dwellers live longer? Exp Gerontol. 2001, 36(4-6), 739-64.

Carey J, Judge D (Ed.). Longevity records: life spans of mammals, birds, reptiles, amphibians and fish. [S.l.]: Odense University Press, 2000.

Carrel A. On the permanent life of tissues outside of the organism. $J$ Exp Med. $1912,15(5), 516-28$.

Caspari R, Lee SH. Older age becomes common late in human evolution. Proc Natl Acad Sci U S A. 2004, 101(30), 10895-900.

CDC C. Vital Statistics / VitalStats. 2010. Disponível em:

$<$ www.cdc.gov/nchs/vitalstats.htm $>$.

Cebrat S. Penna model from the perspective of one geneticist. Physica A: Statistical Mechanics and its Applications. 1998, 258(3-4), 493-498.

Cerami A. Hypothesis. glucose as a mediator of aging. J Am Geriatr Soc. 1985, $33(9), 626-34$.

Charlesworth B. Evolution in Age Structured Populations. Cambridge: Cambridge University Press, 1980.

Charlesworth B. Patterns of age-specific means and genetic variances of mortality rates predicted by the mutation-accumulation theory of ageing. J Theor Biol. 2001, $210(1), 47-65$.

Charlesworth B. Fundamental concepts in genetics: effective population size and patterns of molecular evolution and variation. Nat Rev Genet. 2009, 10(3), 195-205.

Charmantier A et al. Quantitative genetics of age at reproduction in wild swans: support for antagonistic pleiotropy models of senescence. Proc Natl Acad Sci U S A. 2006, 103(17), 6587-92.

Chow SS et al. Adaptive radiation from resource competition in digital organisms. Science. 2004, 305(5680), 84-6.

Comfort A. The Biology of Senescence. New York: Rinehart \& Company, Inc., 1956. 
Congdon JD et al. Hypotheses of aging in a long-lived vertebrate, blanding's turtle (emydoidea blandingii). Exp Gerontol. 2001, 36(4-6), 813-27.

Cortopassi GA. Fixation of deleterious alleles, evolution and human aging. Mech Ageing Dev. 2002, 123(8), 851-5.

Crow JF, Maruyama T. The number of neutral alleles maintained in a finite, geographically structured population. Theor Popul Biol. 1971, 2(4), 437-53.

Curtsinger JW et al. Demography of genotypes: failure of the limited life-span paradigm in drosophila melanogaster. Science. 1992, 258(5081), 461-3.

Darwin C. On the origin of species by means of natural selection, or the preservation of favoured races in the struggle for life. London: John Murray, 1859. Disponível em: <http://darwin-online.org.uk>.

Darwin C. The descent of man, and selection in relation to sex. London: John Murray, 1871. Disponível em: <http://darwin-online.org.uk>.

Darwin C. The origin of species by means of natural selection, or the preservation of favoured races in the struggle for life. London: John Murray, 1872. Disponível em: <http://darwin-online.org.uk>.

Dawkings R. The Ancestor's Tale: A Pilgrimage to the Dawn of Evolution. New york: Houghton Miffin, 2005.

de Bruin JP et al. Ovarian aging in two species of long-lived rockfish, sebastes aleutianus and s. alutus. Biol Reprod. 2004, 71(3), 1036-42.

de Magalhães JP. Open-minded scepticism: inferring the causal mechanisms of human ageing from genetic perturbations. Ageing Res Rev. 2005, 4(1), 1-22.

de Magalhães JP, Cabral JAS, Magalhaes D. The influence of genes on the aging process of mice: a statistical assessment of the genetics of aging. Genetics. 2005, 169(1), 265-74.

de Magalhães JP, Costa J, Church GM. An analysis of the relationship between metabolism, developmental schedules, and longevity using phylogenetic independent contrasts. J Gerontol A Biol Sci Med Sci. 2007, 62(2), 149-60.

de Magalhães JP, Toussaint O. The evolution of mammalian aging. Exp Gerontol. 2002, 37(6), 769-75.

Djawdan $\mathrm{M}$ et al. Metabolic reserves and evolved stress resistance in drosophila melanogaster. Physiol Zool. 1998, 71(5), 584-94.

Dobzhansky T. Nothing in biology makes sense except in the light of evolution. American Biology Teacher. 1973, 35, 125-129. 
Drack M, Apfalter W, Pouvreau D. On the making of a system theory of life: Paul a weiss and ludwig von bertalanffy's conceptual connection. Q Rev Biol. 2007, 82(4), 349-73.

Economos A. A non-gompertzian paradigm for mortality kinetics of metazoan animals and failure kinetics of manufactured products. AGE. 1979, 2, 74-76, 10.1007/BF02432250.

Economos AC. Kinetics of metazoan mortality. Journal of Social and Biological Structures. 1980, 3, 317-329.

Economos AC. Rate of aging, rate of dying and the mechanism of mortality. Arch Gerontol Geriatr. 1982, 1(1), 3-27.

Economos AC. Rate of aging, rate of dying and non-gompertzian mortality encore.... Gerontology. 1985, 31(2), 106-11.

Economos AC, Lints FA. Growth rate and life span in drosophila v. the effect of prolongation of the period of growth on the total duration of life (j.h. northrop, 1917)-revisited. Mech Ageing Dev. 1985, 33(1), 103-13.

Edlund JA, Adami C. Evolution of robustness in digital organisms. Artif Life. 2004, 10(2), 167-79.

Edrey YH et al. Endocrine function and neurobiology of the longest-living rodent, the naked mole-rat. Exp Gerontol. 2011, 46(2-3), 116-23.

Edwards AWF. The fundamental theorem of natural selection. Theor Popul Biol. 2002, 61(3), 335-7.

Ericsson $\mathrm{G}$ et al. Age-related reproductive effort and senescence in free-ranging moose, alces alces. Ecology. 2001, (82), 1613-1620.

Felsenstein J. Inbreeding and variance effective numbers in populations with overlapping generations. Genetics. 1971, 68(4), 581-97.

Finch CE, Pike MC. Maximum life span predictions from the gompertz mortality model. J Gerontol A Biol Sci Med Sci. 1996, 51(3), B183-94.

Finch CE, Pike MC, Witten M. Slow mortality rate accelerations during aging in some animals approximate that of humans. Science. 1990, 249(4971), 902-5.

Fisher R. The Genetical Theory of Natural Selection. New York: Oxford University Press, 1930.

Flatt T, Tu MP, Tatar M. Hormonal pleiotropy and the juvenile hormone regulation of drosophila development and life history. Bioessays. 2005, 27(10), 999-1010.

Fletcher R. Epidemiologia Clinica : Elementos Essenciais. [S.l.]: Artmed, 2006. 
Floud R, Harris B. Health, Height and Welfare: Britain 1700-1980. Chicago: Chicago University Press, 1996.

Fries JF. Aging, natural death, and the compression of morbidity. $N$ Engl $J$ Med. 1980, 303(3), 130-5.

Fukui HH, Pletcher SD, Curtsinger JW. Selection for increased longevity in drosophila melanogaster: a response to baret and lints. Gerontology. 1995, 41(2), $65-8$.

Futuyma D. Evolution. Sunderland, MA, U.S.A.: Sinauer Associates, 1998.

Gavrilov LA, Gavrilova NS. The reliability theory of aging and longevity. $J$ Theor Biol. 2001, 213(4), 527-45.

Gavrilov LA, Gavrilova NS. Reliability theory of aging and longevity. In: Masoro EJ, Austad SN (Ed.). Handbook of the Biology of Aging. 6th. ed. San Diego: Academic Press, 2006. 3-40.

Gibbs AG, Chippindale AK, Rose MR. Physiological mechanisms of evolved desiccation resistance in drosophila melanogaster. J Exp Biol. 1997, 200(Pt 12), $1821-32$.

Gillespie J. Population genetics : a concise guide. Baltimore, Md: The Johns Hopkins University Press, 1998.

Golubev A. Does makeham make sense? Biogerontology. 2004, 5(3), 159-67.

Gompertz B. On the nature of the function expressive of the law of human mortality and on a new mode of determining life contingencies. Philos Trans Roy Soc London. 1825, (115), 513-85.

Guillaume F, Rougemont J. Nemo: an evolutionary and population genetics programming framework. Bioinformatics. 2006, 22(20), 2556-7.

Haldane JBS. A mathematical theory of natural and artificial selection. part 1. Transactions of the Camrbidge philosophical society. 1924, 23, 19-41.

Haldane JBS. New Paths in Genetics. London: Allen and Unwin, 1941.

Hall WJ. The doctors of time. Ann Intern Med. 2000, 132(1), 18-24.

Hamilton WD. The genetical evolution of social behaviour. i. J Theor Biol. 1964, $7(1), 1-16$.

Hamilton WD. The moulding of senescence by natural selection. J Theor Biol. 1966, 12(1), 12-45.

Harman D. Aging: a theory based on free radical and radiation chemistry. $J$ Gerontol. 1956, 11(3), 298-300. 
Harman D. The aging process. Proc Natl Acad Sci U S A. 1981, 78(11), 7124-8.

Harman D. Aging: phenomena and theories. Ann N Y Acad Sci. 1998, 854, 1-7.

Harman D. Free radical theory of aging: an update: increasing the functional life span. Ann N Y Acad Sci. 2006, 1067, 10-21.

Hartl DL, Clark AG. Princípios de Genética de Populações. 4th. ed. Porto Alegre: Artmed, 2010.

Hayflick L. The limited in vitro lifetime of human diploid cell strains. Exp Cell Res. $1965,37,614-36$.

Hayflick L. Theories of biological aging. Exp Gerontol. 1985, 20(3-4), 145-59.

Hayflick L. How and why we age. Exp Gerontol. 1998, 33(7-8), 639-53.

Hayflick L. The future of ageing. Nature. 2000, 408(6809), 267-9.

Hayflick L, Moorhead PS. The serial cultivation of human diploid cell strains. Exp Cell Res. 1961, 25, 585-621.

Hilborn R, Mangel M. The ecological detective. Confronting models with data. Princeton, NJ.: Princeton University Press, 1997.

Hoffmann J. Darwin and computational ecology: How simple computational models of evolution help our search for better models of ecological systems. In: Barra V, Troer M (Ed.). Keynote Address: In Proceedings of Open International Conference on Modeling and Simulation OICMS 2005. France: Blaise Pascal University, 2005. $27-39$.

Hoffmann JP. Simultaneous inductive and deductive modeling of ecological systems via evolutionary computation and information theory. Simulation. 2006, 82(7), 439-450.

Holliday R. Understanding ageing. Philos Trans R Soc Lond B Biol Sci. 1997, 352(1363), 1793-7.

Holliday R. Ageing and the extinction of large animals. Biogerontology. 2005, 6(2), $151-6$.

Houle D, Rowe L. Natural selection in a bottle. Am Nat. 2003, 161(1), 50-67.

Hughes KA et al. A test of evolutionary theories of aging. Proc Natl Acad Sci U S A. 2002, 99(22), 14286-91.

Hughes KA, Charlesworth B. A genetic analysis of senescence in drosophila. Nature. 1994, 367(6458), 64-6. 
Hughes KA, Reynolds RM. Evolutionary and mechanistic theories of aging. Annu Rev Entomol. 2005, 50, 421-45.

Jacob Filho W, Monaco TO. A geriatria no século XXI. In: Lopes AC (Ed.). Tratado de Clínica Médica. 2. ed. São Paulo: Editora Roca Ltda., 2009. 3, cap. 411, $4254-4260$.

Jeckel-neto EA, da Cunha GL. Teorias biológicas do envelhecimento. In: de Freitas EV et al. (Ed.). Tratado de Geriatria e Gerontologia. Rio de Janeiro: Editora Guanabara Koogan, 2002.

Keyfitz N. Applied mathematical demography. New York, NY: Springer, 2005.

Kimura M. Evolutionary rate at the molecular level. Nature. 1968, 217(5129), $624-6$.

Kimura M, Crow JF. The number of alleles that can be maintained in a finite population. Genetics. 1964, 49, 725-38.

Kirkwood TB. Evolution of ageing. Nature. 1977, 270(5635), 301-4.

Kirkwood TB, Austad SN. Why do we age? Nature. 2000, 408(6809), 233-8.

Kirkwood TB, Holliday R. Commitment to senescence: a model for the finite and infinite growth of diploid and transformed human fibroblasts in culture. $J$ Theor Biol. 1975, 53(2), 481-96.

Kirkwood TB, Holliday R. The stability of the translation apparatus. J Mol Biol. 1975, 97(2), 257-65.

Kirkwood TB, Holliday R. The evolution of ageing and longevity. Proc $R$ Soc Lond B Biol Sci. 1979, 205(1161), 531-46.

Kirkwood TB, Rose MR. Evolution of senescence: late survival sacrificed for reproduction. Philos Trans $R$ Soc Lond B Biol Sci. 1991, 332(1262), 15-24.

Kirkwood TBL. Evolution of ageing. Mech Ageing Dev. 2002, 123(7), 737-45.

Kirkwood TBL. Understanding ageing from an evolutionary perspective. $J$ Intern Med. 2008, 263(2), 117-27.

Kirkwood TBL et al. Computer modeling in the study of aging. In: Handobook of the Biology of Aging. London, UK: Oxford University Press, 2006.

Kitano H. Foundations of systems biology. Cambridge, Massachusetts: The MIT Press, 2001.

Knight JA. The biochemistry of aging. Adv Clin Chem. 2000, 35, 1-62.

Kowald A. Lifespan does not measure ageing. Biogerontology. 2002, 3(3), 187-90. 
Koza J. Genetic Programming - On the Programming of Computers by Means of Natural Selection. Cambridge: MIT Press, 1992.

Kuchel GA. Aging and homeostatic regulation. In: Jeffrey B et al. (Ed.). Hazzard's geriatric medicine and gerontology. New York: McGraw-Hill Medical, 2009.

Kurtz EB, Winfrey R. Life-characteristics of physical property. Bull. Iowa Engineering Exp. Station. 1938, 103(33).

Lenski RE et al. Genome complexity, robustness and genetic interactions in digital organisms. Nature. 1999, 400(6745), 661-4.

Lenski RE et al. The evolutionary origin of complex features. Nature. 2003, 423(6936), 139-44.

Lichtheim M. Ancient Egyptian literature; a book of readings. Berkeley: University of California Press, 1973.

Linnen C, Tatar M, Promislow DE. Cultural artifacts: a comparison of senescence in natural, laboratory-adapted and artificially selected lines of drosophila melanogaster. Evol Ecol Res. 2001, 3, 877-888.

Loeb J, Northrop JH. On the influence of food and temperature upon the duration of life. Journal of Biological Chemistry. 1917, 32(1), 103-121.

Luckinbill LS, Clare MJ. Selection for life span in drosophila melanogaster. Heredity. 1985, 55 ( Pt 1), 9-18.

Makeham WM. On the law of mortality and the construction of annuity table. $J$. Inst. Actuaries and Assur. Mag. 1860, 8, 301-310.

Masoro EJ. A discussion of the aging process: current theories. Drug Nutr Interact. 1985, 4(1-2), 35-41.

Masoro EJ. Are age-associated diseases an integral part of aging? In: Masoro EJ, Austad SN (Ed.). Handbook of the Biology of Aging. 6th. ed. London, UK: Academic Press, 2006. 43-62.

Masoro EJ, Austad SN. Handbook of the Biology of Aging. Sixth edition. London, UK: Oxford Academic Press, 2006.

Massad E. A matemática das populações. In: Massad E et al. (Ed.). Métodos quantitativos em Medicina. Barueri, SP: Editora Manole Ltda., 2004.

Maynard Smith J. Evolutionary Genetics. 2. ed. Oxford, UK: Oxford University Press, 1997.

Mccay CM, Crowell MF, Maynard LA. The effect of retarded growth upon the life-span and upon the ultimate body size. Journal of Nutrition. 1935, 10(63). 
Medawar PB. Old age and natural death. Modern Quarterly. 1946, 1, 30-56.

Medawar PB. An unsolved problem of biology. Oxford, UK: H.K. Lewis and Co., 1952. 24 .

Medawar PB. The definition and measurement of senescence. In: Wolstenholme GEW (Ed.). Ciba Foundation Colloquia on Ageing, Volume I. London,: J. \& A. Churchill, 1955. 4-15.

Medvedev ZA. An attempt at a rational classification of theories of ageing. Biol Rev Camb Philos Soc. 1990, 65(3), 375-98.

Merry BJ. Biological mechanisms of ageing. Eye (Lond). 1987, 1 ( Pt 2), 163-70.

Miller RA et al. Longer life spans and delayed maturation in wild-derived mice. Exp Biol Med (Maywood). 2002, 227(7), 500-8.

Minot CS. The problem of age, growth and death; a study of cytomorphosis, based on lectures at the Lowell Institute. London: Lowell Institute, 1908.

Moss de Oliveira S, Alves D, Sa Martins JS. Evolution and ageing. Physica A. $2000,285,77-100$.

Munshi-south J, Wilkinson GS. Bats and birds: Exceptional longevity despite high metabolic rates. Ageing Res Rev. 2010, 9(1), 12-9.

O'neill B. Digital evolution. PLoS Biol. 2003, 1(1), E18.

Orell M, Belda EJ. Delayed cost of reproduction and senescence in the willow tit parus montanus. Journal of Animal Ecology. 2002, 71(1), 55-64.

Orgel LE. The maintenance of the accuracy of protein synthesis and its relevance to ageing. Proc Natl Acad Sci U S A. 1963, 49, 517-21.

Osborne TB, Mendel LB, Fey EL. The effect of retardation of growth upon the breeding period and duration of life in rats. Science. 1917, 45, 294-295.

Pearl R. The rate of living. New York: Alfred Knopf, 1928.

Penna TJP. A bit-string model for biological aging. Journal of Statistical Physics. March 1995, 78(5-6), 1629-1633.

Penna TJP, Stauffer D. Efficient monte carlo simulation of biological aging. Int. J. Mod. Phys. C,. 1995, 6(2), 233-239.

Promislow DE et al. Age-specific patterns of genetic variance in drosophila melanogaster. i. mortality. Genetics. 1996, 143(2), 839-48.

Promislow DEL. Senescence in natural populations of mammals: A comparative study. Evolution. 1991, 45(8), 1869-1887. 
Promislow DEL, Fedorka KM, Burger JMS. Evolutionary biology of aging: Future directions. In: Masoro EJ, Austad SN (Ed.). Handbook of the Biology of Aging. 6th. ed. London, UK: Academic Press, 2006. 217-242.

Reid JM et al. Age-specific reproductive performance in red-billed choughs pyrrhocorax pyrrhocorax: patterns and processes in a natural population. Journal of Animal Ecology. 2003, 72(5), 765-776.

Reznick DN et al. Effect of extrinsic mortality on the evolution of senescence in guppies. Nature. 2004, 431(7012), 1095-9.

Rice SA. Encyclopedia of Evolution. New York: Facts On File, Inc., 2007.

Ricklefs RE. Evolutionary theories of aging: confirmation of a fundamental prediction, with implications for the genetic basis and evolution of life span. Am Nat. 1998, 152(1), 24-44.

Robine J, Allen J. Jeanne calment: validation of the duration of her life. In: Jeune B, Vaupel J (Ed.). Validation of Exceptional Longevity. Odense: Odense University Press, 1999. cap. Jeanne Calment: validation of the duration of her life., 145-61.

Rose M, Charlesworth B. A test of evolutionary theories of senescence. Nature. 1980, 287(5778), 141-2.

Rose MR. Evolutionary biology of aging. 1. ed. Oxford, UK: Oxford University Press, 1991.

Rose MR et al. Evolution of ageing since darwin. J Genet. 2008, 87(4), 363-71.

Rose MR, Charlesworth B. Genetics of life history in drosophila melanogaster. i. sib analysis of adult females. Genetics. 1981, 97(1), 173-86.

Saino $\mathrm{N}$ et al. Humoral immune response in relation to senescence, sex and sexual ornamentation in the barn swallow (hirundo rustica). J Evol Biol. 2003, 16(6), $1127-34$.

Semsei I. On the nature of aging. Mech Ageing Dev. 2000, 117(1-3), 93-108.

Sgro CM, Partridge L. A delayed wave of death from reproduction in drosophila. Science. 1999, 286(5449), 2521-4.

Shock NW. Physical activity and the "rate of ageing". Can Med Assoc J. 1967, 96(12), 836-42.

Shock NW. Normal human aging: the Baltimore longitudinal study of aging. Washington, DC: U.S. Government Printing Office., 1984.

Silveira PSP. Modelo computacional para o estudo da mecânica e da conectividade do músculo liso de vias aéreas. Tese (Livre Docência) — Faculdade de Medicina da Universidade de São Paulo, São Paulo, 2006. 
Silveira PSP, Massad E. Modeling and simulating morphological evolution in an artificial life environment. Comput Biomed Res. 1998, 31(1), 1-17.

Sinclair DA, Howitz KT. Dietary restriction, hormesis, and small molecule mimetics. In: Masoro EJ, Austad SN (Ed.). Handbook of the Biology of Aging. 6th. ed. San Diego: Academic Press, 2006. 3-40.

Statistics NC for H. Data Warehouse on Trends in Health and Aging. 2010.

Stein C, Moritz I. A life course perspective of maintaining independence in older age. Geneva, 1999.

Tatar M et al. Age-specific patterns of genetic variance in drosophila melanogaster. ii. fecundity and its genetic covariance with age-specific mortality. Genetics. 1996, $143(2), 849-58$.

Tzafestas E. Aging agents. Artificial Life Robotics. 21 2001, 5, 46-57.

Vaupel J. Trajectories of mortality at advanced ages. In: Wachter K, Finch C (Ed.). Between Zeus and Salmon: The Biodemography of longevity. Washington, DC: National Academy Press, 1997. 17-37.

Verzar F. The stages and consequences of ageing of collagen. Gerontologia. 1969, 15(2), 233-9.

Wagenaar DA, Adami C. Influence of chance, history, and adaptation on digital evolution. Artif Life. 2004, 10(2), 181-90.

Weindruch R. The retardation of aging by caloric restriction: studies in rodents and primates. Toxicol Pathol. 1996, 24(6), 742-5.

Weindruch $\mathrm{R}$ et al. Microarray profiling of gene expression in aging and its alteration by caloric restriction in mice. J Nutr. 2001, 131(3), 918S-923S.

Weindruch R, Walford RL. Dietary restriction in mice beginning at 1 year of age: effect on life-span and spontaneous cancer incidence. Science. 1982, 215(4538), $1415-8$.

Weismann A. Essays upon heredity and kindred biological problems. I. 2n ed.. ed. Amen Corner, E. C.: Oxford University Press Warehouse, 1889. 1-65.

Weismann A. Essays upon heredity and kindred biological problems. II. 2n ed.. ed. Amen Corner, E. C.: Oxford, Clarendon Press, 1892. 1-65.

Wessells RJ et al. Insulin regulation of heart function in aging fruit flies. Nat Genet. 2004, 36(12), 1275-81.

Westendorp RG, Kirkwood TB. Human longevity at the cost of reproductive success. Nature. 1998, 396(6713), 743-6. 
Wilkinson GS, South JM. Life history, ecology and longevity in bats. Aging Cell. 2002, 1(2), 124-31.

Williams GC. Pleiotropy, natural selection and the evolution of senescence. Evolution. 1957, 11, 398-411.

Williams PD, Day T. Antagonistic pleiotropy, mortality source interactions, and the evolutionary theory of senescence. Evolution. 2003, 57(7), 1478-88.

Wilmoth JR. In search of limits. In: Between Zeus and the Salmon. Washington, DC: National Academy Press, 1997. 38-64.

Wright S. Evolution in mendelian populations. Genetics. 1931, 16, 97-159.

Wright S. Size of population and breeding structure in relation to evolution. Science. 1938, 87, 430-431.

Wright S. Modes of selection. The American Naturalist. 1956, 90(850), 5-24. 